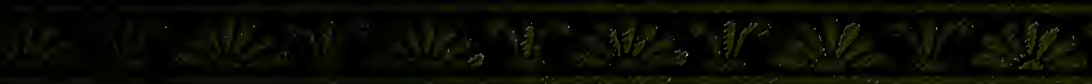
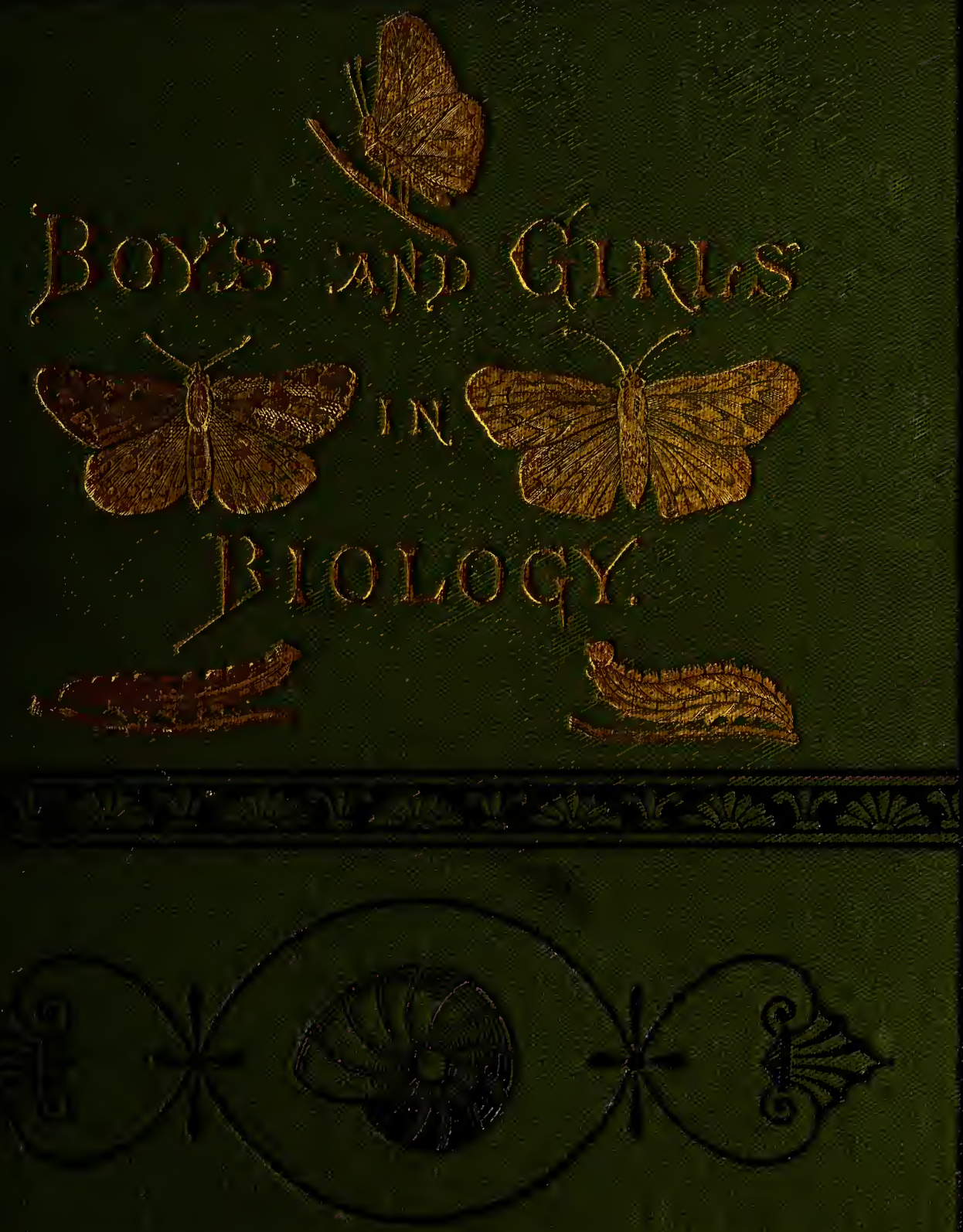





\title{
BOYS AND GIRLS
}

I N

\section{BIOLOG Y;}

OR,

\section{SIMPLE STUDIES OF THE LOWER FORMS OF LIFE,}

\author{
BASED UPON THE
}

\begin{abstract}
LATEST LECTURES OF PROF. T. H. HUXLEY, AND PUBLISHED BY HIS PERMISSION,
\end{abstract}

BY

SARAH HACKETT STEVENSON.

ILLÚSTRATED BY MISS M. A. I. MACOMISH.

\author{
NEW YORK: \\ D. A P P L E T N A N C O M A N Y, \\ $549 \& 551$ B ROA DWAY. \\ 1875.
}


Entered, according to Act of Congress, in the year 1575, by D. APPLETON \& COMPANY,

In the Office of the Librarian of Congress, at Washington.

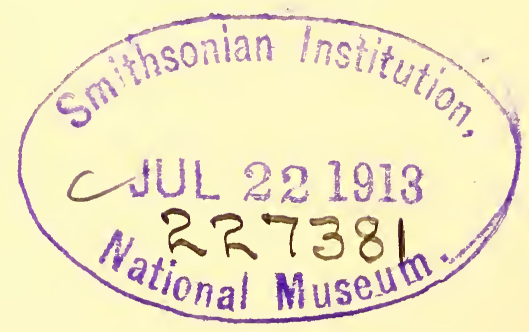




\section{P R E F A C E.}

THE possibility of interesting young people, even little children, in the science of simple things, occurred to me the first time I ever had the pleasure of listening to Professor Huxley. His lucid description of the yeast-plant recalled the play of my childhood, and then and there was suggested the plan of which this volume is the attempted execution. It was originally written in the form of letters from England to my little nephew in America; by a subsequent modification it assumed its present form of scientific talks with Boys and Girls.

Reasoning from the inquiries that children are continually making, and from the unanswered questions asked by myself when a child, I feel there is in the minds of children a need which this work is designed to supply. Even if young people never asked 
or thought about the familiar things around them, so much the more necessity is there for books that will develop this spirit of inquiry. It is often urged that, because of the technical names with which science is loaded, the teaching of it to children is impracticable; and yet geography, itself a master-science when properly taught, is put into the hands of every child with scarcely any thing left in it but the names, whereas, in true scientific teaching the name is invariably associated with the thing itself. Geographical names are for the most part learned abstractly, because of the difficulty the child finds in adjusting the relation of a flat map to the round earth; likewise, the relation of the parts of the earth's surface to the whole.

Again, there seems to my mind far more practicality in teaching to a child first domestic rather than foreign science. It is more essential that he should know the course of his own blood than that he should know the course of the Nile, not but that both are well to know; but, if either must be unknown, let it not be himself. And the way to know himself is first to know the lower forms of life. I use geography as a comparison, becouse no one objects to it as too difficult for children; 
but to teach them about the clover-blossom or the snail that lies coiled beneath it-the life which they every day trample beneath their feet, and which is such a mysterious foreshadowing of their own life-that is all too hard. Biology is too big a subject for boys and girls!

As regards technical terms, I use them; but in every instance the literal meaning is also given, or a paraphrase in language easily understood, together with the scientific name in sMall Capitals, so as to cultivate a pictorial memory - an essential aid to scientific study.

The scope of this volume is this: beginning with the lowest form of vegetable, a characteristic sample of the typical forms of life as far as the vertebrate animals is analyzed (for classification, see closing chapter). At some future time, if this attempt be a success, I intend to undertake a similar work upon the Vertebratce.

Although suggestions are drawn from unscientific sources, even nursery rhymes and stories being worried into witnessing for some of the grandest truths in Nature, yet the subject-matter and the analyses are such that they may be taken as guides to real labora- 
tory work; but the volume is in nowise intended to take the place of a text-book.

An outline of the plan was submitted to Professor Huxley, and it received his entire approval. The whole scientific part of the work, except the butterfly chapter, is based upon the information I received at Professor Huxley's class-lectures in South Kensington Science Schools.

The drawings, as well as the criticism of the scientific text, are the work of Miss Macomish, a prize pupil of Professor Huxley, and a science-teacher in the London schools.

If the book, whose only inspiration is the spirit of my childhood, answers some of the questions in the minds of the boys and girls who chance to read it, and suggests many more than it answers, I shall be glad the spirit came back to me, and shall ask it to come again.

\section{Sarah Hackett Stevenson.}

Chicago, 1874. 


\section{BOYS AND GIRLS IN BIOLOGY.}

\section{CHAPTER I.}

THE FUNGUS, OR COLORLESS PLANT.

What the Boys and Girls found in a Spoonful of Yeast.-Bubbles and Babies, Cooks and Chemists.

UPON the old stone hearth by the kitchen fireplace stood a quaint-looking earthen jar, whose outside, so often spattered with batter, told of the treasures within - the precious buckwheat-cakes.

My early affection for these most questionable articles was most unquestionable; indeed, my heart was in . them from the time they were mixed, with familiar sound, the night before, in the depths of that mysterious jar, till in the morning they foamed over its brim, and over the ladle on to the griddle, and at last yielded themselves, crisp and brown, to the melting influence of fresh butter, maple-syrup, and a good appetite. 
With such memories of the dear old buckwheats, I can but think kindly of them in spite of the advice of doctors and the contempt of foreigners. I do not like to turn against such old friends; yet, now I am obliged to defend them because of their nationality, and not because of their own worth. I plead for them as I plead for pumpkin-pie. I believe in both, because both are genuine American inventions-" my country, right or wrong." But the love of other years was based upon no such poetical illusion-my interest, then, in buckwheat-cakes was in the cakes themselves, their delicious taste, and their curious way of "coming up." How they could be "so light" was almost as great a wonder to us children as how they could be "so good." How could so few handfuls of buckwheat make so many platefuls of cakes? The magic power that turned so little into so much, what was it? Of one thing we felt very certain - the yeast must have something to do with the mystery. So, one day, we determined to find out all about it.

It was a rainy day, and we were playing in the storeroom where all the fruit, flour, and such things, were kept, and where Bridget put her yeast-cakes to dry. This was our chance to put the yeast into the witnessbox and make it speak for itself. First, we pounded up several of the cakes, keeping close watch for any 
thing that looked like the "yeast's spirit" as Charley said; "but, of course, we couldn't see a spirit, if there was one," as Simon said. Then we got some buckwheat and put the yeast into it, stirring and beating it just as they did in the kitchen, intending to watch how the batter came up, thinking that the secret could not hide itself from us in the day-time while we were looking, as it did in the night-time while we were sleeping. But, alas! the experiment was a failure, for the sound of the beating brought Bridget herself in our midst. She was in an awful rage because of the litter we had made and the yeast we had wasted, while we young rogues scampered away as fast as possible, glad to make good our escape. But what have these buckwheat-cakes to do with Science? Well, I had long since forgotten about the queer old jar and our first experiment in the store-room, when, one morning, away over in London, I went to hear a great professor lecture on Brology: that means, he was going to tell about plants and animalsevery thing that has life. Now, I had heard a great deal about this professor, how he believed that the monkeys were our relations, and how he loved to vivisECT, that means, cut up alive, all kinds of animals. So I expected to see a cruel-looking man, doing very cruel things. But I saw nothing of the sort. With a kind and peaceful look, he stood upon a platform at one end 
of the large lecture-room, and what do you think was on the table before him? A cup of yeast-the very thing I wanted to know about!

This was his subject, and, as he talked, it seemed to me, somehow or other, he must have heard of our experimert, else how could he tell just what to say? So clearly did he explain how that old jar foamed over every morning, I thought all you boys and girls would like to hear about it, too; so I shall try to tell you. I am sure I should have been very glad if I had been told something of the kind, instead of being scolded and called a naughty child.

Now, if you will get a little yeast to look at while I talk, you will better understand what I say-just a spoonful or two in a glass or cup will do. Let me tell you that every thing you notice about this yeast has a meaning. I cannot tell you about all the things you may see; but I can tell you about some of them, and, when you get older, you can perform original experiments and find out other things for yourselves. The first thing that you will probably notice about the yeast is, that it bubbles, and these bubbles look something like the soap-bubbles with which you and I have so often played; but we have to make our soap-bubbles, while these seem to make themselves. Soap-bubbles come from the air which is caught in the water, and is 
trying to get away, while the yeast-bubbles are formed by a gas called CARBONIC ACID, which is made by the yeast. It was found by the bursting of these bubbles that they did not contain common air like the soapbubbles, so men began to study yeast to find out what it was that made all this blubbering, and I am going to tell you all they have discovered so far. If you ask me why the air does not stay in the soap-suds and the gas in the yeast, I can tell you only that all kinds of gas, and air, which is made of two kinds of gas, never will stay in any one place unless they are held by strong walls. I have seen you boys and girls sorry when you could not make your toy-balloons stand out again and go to the top of the room, now you know the reason why; the mischievous air inside had found a little hole in the wall of the balloon, and the air outside helped its imprisoned brother to escape through this hole. Now, you are such little Yankees, you will be sure to ask me if this air and gas are so restless, and try so hard to get away from every place, why they do not fly from the earth altogether, and leave us without any thing to breathe, to burn, or to bubble. There is no wall outside the earth to keep them from going, no; but there is a queer something called "АTTRACTION" that makes things fall down instead of up. Somebody found it out one day when he was sitting under an 
apple-tree. I dare say you all know the story. It is this same atTraction which keeps the air down to the earth, and does not let it fly away. How funny it would be to see boys' caps, and balls, and even the boys themselves, go flying up into the sky! What is ATTRACTION? I do not know; you sometimes get your knives magnetized, and then, when you put the knife near a nail, the nail comes right toward it. The force that draws the knife is one kind of attraction. The centre of the earth is something like the magnetized knife ; it makes every thing on the surface come toward it, and keeps us all from flying away nobody knows where. So much for the gas that makes the yeastbubbles. The next thing you will notice is the brownịsh color of the yeast. As it stands, it grows thicker and more muddy-looking, and, in the course of an hour or so, it begins to rise, as the cook says; the chemists call this rising FERMENTATION, and the Biologists call it GRowING. You will find that your spoonful has grown into a cupful running over. It is just as though a farmer should sow a handful of wheat, and, for every grain of wheat he sows, he finds a hundred grains in the harvest. So you sow the yeast in the sugar and water, which is its soil, or NIDUs, as the scientific men call it, and you have all this harvest of new yeast. Perhaps you are ready now to understand why the profes- 
sor began his lectures with yeast instead of an elephant or a monkey. The yeast is really alive, and it is one of the simplest forms of life of which we know; so, in order to study Brology, or the Science of Life, we begin at what seems to be the beginning. Now, where does this life stay in the yeast? You see, the yeast is not solid like wheat or corn, but liquid like milk or soup; but milk is not alive, you cannot sow it; nor will it grow and make more milk, else the milkmen would soon be finding it out, and what large crops of milk they would sow!

All that I have described, you can see with your own eyes, but now I must begin to tell you something about the yeast which you could never find out with your eyes alone, sharp as they are. It is not liquid, like the milk, but contains a great many little solid bodies floating about in it, and so small that you cannot see them with the naked eye. They never would have been seen had it not been for the microscope. The word is made of two words, which mean "little" and " to view," so this instrument makes little objects look many hundred times larger than they are; for instance, the dust which rubs off on your fingers from the butterfly's wing, looks as large as the feathers of a canary-bird. You must find out who invented the microscope, and save your pin-money till you get enough to buy one. 
You can soon learn to use it, and it will give you more pleasure than all the toys in old Santa Claus's pack, with his sled and reindeers thrown in. You can never get tired of it as you tire of toys, for it will always show you something new. The first man who looked at yeast through a MICROSCOPE, saw these little bodies floating about, but he did not know at all what they were; he thought they might be bits of barley. Sometimes they are found quite alone (Figs. 1-3), but most frequently

Fig. 1.
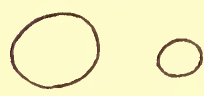

Round Celis.
Fig. 2.

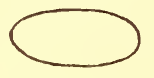

Lemon-silaped Cells.

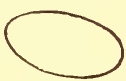

Fig. 3.

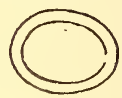

Outer and InNer SurFACE OF SAC.

they are seen all joined together in groups, like boys and girls at play (Figs. 4, 5). Each one is about one

FIG. 5.

Fig. 4

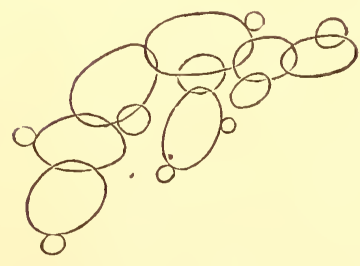

Group of Cells.

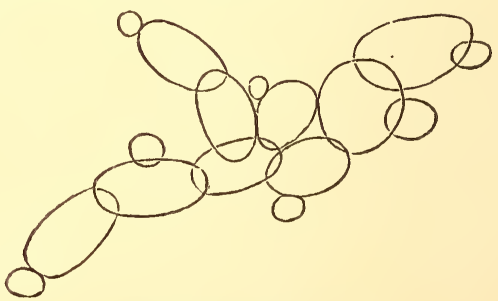

Grodp of Cells.

three-thousandth of an inch in size, that is, if you were to take a piece of an apple about an inch 
long, and divide it into three thousand equal pieces, each piece would be the size of one of these little solid bodies in the yeast. Some of them are even four times smaller-regular little Tom Thumbs! Though they are solid, yet we can see through them, just as we can see through glass, hence they are called TRANsparENT. Now you see why the yeast looks like a fluid, because these bodies are so small and so clear, or TRANSPARENT. Next I want you to notice their shape; they are always round, some of them not as round as your balls, more like a lemon; but none of them are square like a block, or flat like a three-cent piece. The cover of each one is double, that is, it has an outside and an inside, just as your ball-covers have an outer and an inner surface. When you look through the MICRoscope, these two surfaces look like two round lines-one within the other (Fig. 6). Inside these lines you will notice something

FIG. 6.

Fig. 7.

FIG. 8.
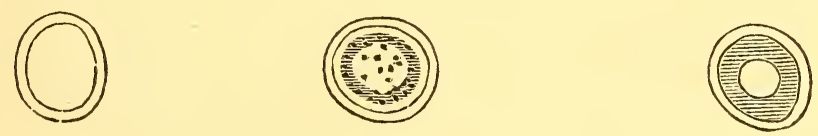

which looks like little grains (Fig. 7), and this whole cover, with all that is inside of it, is called a celL. Now you must learn of what these cells are made. First, there is the outside part which is like a bag, or sac, 
something like a ball-cover, if it were white and clear, or transparent. This bag, or ball-cover, is tough and solid, and, instead of being filled with yarn or Indiarubber, it is full of a soft, jelly-like substance, which is thick and brownish next the wall of the bag, but thinner and more transparent toward the centre (Fig. 8). This jelly is called protoplasu, which means first form, or mould, and the thin space in the centre is an air-cell, or vacule (Fig. 9). If you color the yeast-cells, you

FIG. 11.

Fig. 9.

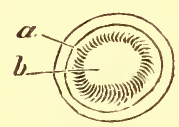

Yeast-cell, or TORUla. $a$, Jelly, or Protgplasm; ๖, Thin Space, or VACUOLE.
FIG. 10.

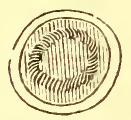

Jelly stained, and the Sac clear.

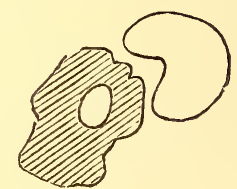

Broken Cell. Sac clear, Jelly stained.

can see the different parts much better, a drop of $m a$ genta will pass right through the sac without staining it at all; the cell-jelly, or PRotopLasm, will be quite red, and the thin spot, or VACUOLE, will not be colored, though it may look pinkish because you look at it through a layer of red jelly, or protoplasm (Figs. 10, 11). Now, if the cell were all made of the same material, it would probably all be colored by the magenta. Chemists have found that this sac or ball-cover is made of the same materials as the cells of wood. It is called 
CELlulose, and it is mixed with a little water and MINERAL MATTER to make the cell-wall. The cell-jelly, or PRoToplasm, is made of water, PROTEIN, MINERAL MATTERs, and fats. We know what all these things are, except the protern. The water is made of two substances -HYDROGEN and oxyGEN; the CELlulose or woody fibre is made of three kinds of matter-CARBON, HYDROGEN, and oXYGEN; and the fat is made of CARBON, HYDROGEN, and OXYGEN. We know the protein contains CARBON, HYDROGEN, OXYGEN, and NITROGEN, with either sulPHuR or PHOSPHORUs-perhaps both. It is very common, because it is found in all living matter; there is no life without it, so it has been called "the foundation of life," yet no one knows very much about it. When you begin to make experiments for yourselves, perhaps you can discover how it is made. I want each one of you to remember this word "protein," because it is the name of the most important thing in your body. The word means first or chief, and by-andby I want to show you how it is something about this PRoTEIN, or "foundation of life," that makes one of the greatest differences between your body and your spoonful of yeast.

If you ask me what the CARBON, OXYGEN, HYDROGEN, and NITROGEN are, I can tell you only that they belong to what are called the sIMPLE ELEMENTs, that 
means, each of them is made of only one kind of matter. Every substance in the world except the metals and minerals, such as gold, sulphur, etc., is made up of two or more of these four smple elements. Carbon comes from a word which means coal, and charcoal is one form of CARBON - the diamond is another. OxyGEN means a producer of acid; it was so called, because it was supposed that it had a great power to make acids. It is the most abundant of all the elements, and it is so necessary to animal life, that it has been called "vital air;" more than seven million tons of it is breathed every day. HYDRogen means water-producer. Water is made of Hydrogen and oxyGen. This is the lightest of all the elements, so that balloons are always filled with hydrogen gas. Nitrogen means the producer of nitre. It helps to make the air we breathe and the PRotein that we feed upon. Now that we have pointed out and named the different parts of each cell, and found out what they are all made of, let us see if we can discover the use of each part. First, the tough, woody sac seems to hold and protect the soft cell-jelly or PRoToplasm. The jelly, or rather the proteIn, which is the chief part of the jelly, is the substance which makes the cell alive. This is the first form of life of which we know-just a simple sac filled with PRotern, which looks like the white of an egg. All the living things 
of the earth begin to grow from such tiny cells. The little grains or GRANULES we find in the yeast-cells are probably the little bits of food which have been taken in, as we shall soon see. The thin space toward the centre seems to be a drop of watery fluid separated from the rest of the jelly, which you know contains a good deal of water.

These yeast-cells have a very pretty name, so I think I will give it to you before I go any further. They are called toruLe-a single one is a torula. The word means a little knobby swelling. You will see after a while how it comes to have this name. If you have followed me carefully-better still, if you have seen it all for yourselves under the MICRoscope-you know that

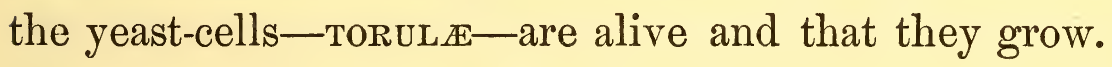
Every thing that grows must have food; you could not grow to be men or women without "bread-and-butter." Now, where does our knobby friend, the rorula, get its "bread-and-butter?" From the liquid in which it floats. What is this liquid? The greater part is water; so we might think we had found the original " cold-water doctor" - the inventor of hydropathy; yet, if you sow yeast in pure water, it will hardly grow at all. But if you put in ever so little sugar, it will smack its lips and froth and bubble considerably. It must be a regular little номळоратн, because, if besides 
the sugar you give it the least little bit of ammonis, MAGNESIA, LIME, and POTASH, it will thrive splendidly and grow like a little weed, only it does not grow in the same way as the weed. The rorula takes in its "little pills" and churns them into that "elixir of life" or PRotein, woody cells or celluLose and fat; then if you watch carefully, you will see a whole lot of little buds coming out round the edges of the wall; hence, the torula is really a little knobby swelling (Fig.

FIG. 12.

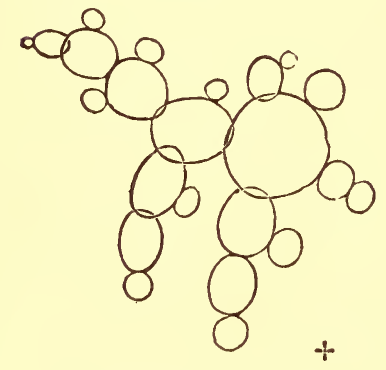

FIG. 13.

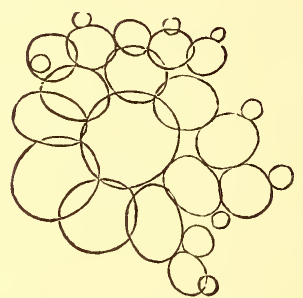

Cell and its Buds. The Baby Torule grouped around their Motier.

12). Some of the buds have other buds at their edges; all these buds are the little baby TORuL $x$, and by-and-by they break away from the old mother torula, and go to house-keeping for themselves. They always pay visits back and forth, and sometimes build their houses right next the parental roof, in clusters like a pop-corn ball (Fig. 13), and at other times they build them in long rows like a chain, or a string of beads (Fig. 14). 
And, if there isn't room inside, they go outside, just as they did in the old buckwheat-jar. After all, Charley. was not so wrong, for these torulæ are the little spirits of the yeast.

Of this you may be sure, every tonuLa has a mother. Topsy, you know, said "she never was born, never had a mother," that she just "growed up;" but Topsy was mistaken, so are the people mistaken who say that тo-

FIG. 14.

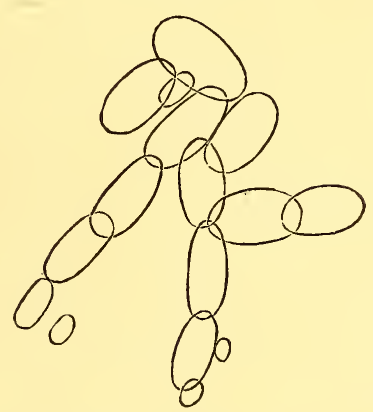

Cells linked together in Chains.

RULस just grow up. Poor Topsy did not know the scientific name for being born without a parent-the wise men call it spontaneous generation. Some people have been trying to prove for two hundred years or more that these little specks of life can make themselves. I will tell you how you can prove that this is not true. Heat kills these little fellows; you know the cook has to be careful not to mix her bread with water that is too 
hot, and not to let it stand too near the fire. Take two bottles and half fill them with sweetened water, or, what is better, "Pasteur's fluid," " and sow just a drop or two of yeast in each, heat them both till they boil, and as they are cooling, cork them up with cotton, or "cottonwool," as the English say. Let them stand for a few days, and there will be no signs of life in either, but if you place just one of the TORULe into one of the bot-

Fig. 16.

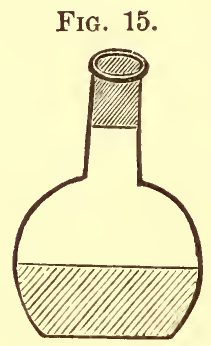

BotTle of YEAST CORKED UP WITH CotTon.

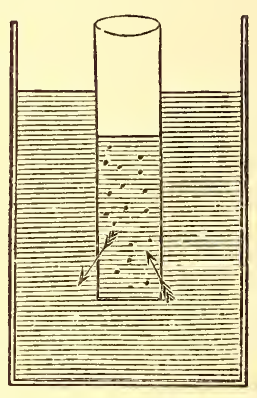

Porous Jar containing Yeast, showing HOW THE FLUIDS PASS IN AND OUT, but the Cells do Not.

tles and cork it up again, the cell will begin to grow and multiply, or FERMent, till the bottle bursts. The other bottle will remain perfectly quiet (Fig. 15); the

${ }^{1}$ Potassium phosphate............... 20 parts.

Calcium phosphate................ 2 "

Magnesium sulphate................ 2 "

Ammonium tartrate................ 100 "

Cane-sugar.................... 1,500 "

Water..................... 8,376 " 
heat has killed all the ToRuL $\approx$ that were inside, and the "cotton-wool" acts as a strainer, and will not allow any of these germs or cells which might be floating in the air to pass through it. I have seen bottles more than a year after they had been corked in this way, and yet there was no sign of bubbling or FERMENTATION in the fluid. If the cells could make themselves, surely, in such a bottle they have time and opportunity. Cotton is the best air-strainer that has ever been discovered; if you are ever in a place where the air is filled with fine mineral dust or poisonous matter, you can prevent it from entering your lungs by breathing through a piece of cotton. Such a filter is called a RESPIRATOR. Common clay jars, like your mammas' flower-pots, are also good filters for the yeast. These jars are full of tiny holes, or PoREs, too small to be seen. If you put some yeast in one of these porous jars, and set this one in a larger jar containing sweetened water, the yeast-fluid will pass out and the sweet-fluid will pass in; the two will thus mix together (Fig. 16), but there will be no bubbling or FERMENTATION in the outer jar, because the TORULe cannot pass through the POREs or little holes of the jar, the cells are so much larger than the holes.

These little yeast-cells float about in the air, or lie asleep in any place where it is dry and comfortable, and never show that they are alive or awake till they are 
planted in some nest, or Nidus. When the cook dries her yeast-cakes, she puts all the little rorul $\&$ to sleep, and then they go into winter quarters, or hibernate in their cells like the bears in their caves, and some of them sleep longer than old Rip Van Winkle himself.

There is another appearance of yeast about which I have not told you; if you let your cup of yeast stand long enough, and do not add any more sugar or water to it, you will notice that the bubbling or FERMENTATION stops, the Torule cells settle to the bottom, and the fluid comes to the top. The fluid has a strong or biting instead of a sweet taste, like the fluid into which you first placed the yeast. The Fermentation has changed its nature-the TORUL their wands, have turned the sugar into CARBONIC ACID, ALCOHOL, GLYCERINe, and succinic ACID. These are called the Products of FERMENTATION. The CARBonic ACID, you know, passed off through the bubbles; the other products are still in the fluid. If you taste a little of this fluid it will make you merry, if you take much of it you will become intoxicated; this is due to the ALCOHOL, and the value of yeast depends upon its power to make ALCOHOL. The distiller takes this fluid, and separates the ALCOHOL by a process called DIsTILLATION. If you had a RETORT, you might distill some for yourselves. You may know that the fluid is Alcorror, 
if, when you touch it with a lighted match, it burns with a blue flame. But you must be careful in making this experiment, as the internal-revenue officer might arrest you for illicit distillation. I advise you never to drink the AlcoHou which you or anybody else may distill, because it is very injurious. Now I have told you the ToRula grows; it has life, but how does it grow -as a MiNeral, a vegetable, or an ANIMAL? Minerals have a kind of growth, but the new matter which a mineral adds to itself is placed externally, not internally. The mineral grows larger and larger by additions made to its outside, as the snowballs get larger and larger when you roll them along the snow, or as candles become thicker and thicker as they are dipped into the melted tallow. This is called growth by ACCRETIon, but the ToRula or yeast-cell grows by taking in new substance in among the particles of its old substance, and this kind of growth is called by a long, name-rNTusSUSCEPTION. This is one of the reasons why it is not a mineral: is it an animal? The line that divides the animal from the vegetable kingdom is not very well marked, but there are two reasons why the ToRula is not an animal. In the first place, its jelly or РRотоPLASM is shut up in a close sac; you remember the tough, woody CEILLLose that I compared to a ball-cover is the sac, but the PRoToplasm-jelly of animal cells 
forms a wall of itself. In the second place, the ToRuLA can make its own food, or PRoTEIN, out of the raw material it finds in the liquid, while the animal-cells seem to have no such power; they must have their PRoteIn all ready made, and their work is to destroy it. So if the TORULA is not a MINERAL nor an ANIMAL, it must be a VEGETABLE. Vegetables are the MANUfacturERs or PRoDUCERS of PROTEIN; animals are the DESTROYERS Or CONsuMERs of it. This is why I asked you to remember PRoTeIN : plants can make it, animals cannot, and this is one great difference between plants and animals or between you and your spoonful of yeast. And so you might call the vegETABLE KINGDom Nature's big kitchen, where the MINERAL KINGDOM is cooked and made ready to be eaten by the ANIMAL KINGDom. The vegetablecells with their white sacs are the little cooks in white aprons; how clean they are, and how fast they work! They are such intelligent little creatures, too, they never burn up the dinner nor let it sod, for they know just how to regulate the heat of their ovens. They do not spoil your digestion with pastry or confections, and they are so economical, that they never let a bit of any thing go to waste. If we had such cooks in our kitchens, we should never die of dyspepsia or poverty. Some plants have been noticed standing outside the kitchen-door, catching flies, stray bits of meat, or any 
ready-made food that comes in their way, eating with an appetite and digestion worthy of the fat boy in "Pickwick." The Venus fly-trap not only traps the poor flies, but eats them; so it seems that some plants have the power of not only making, but of destroying PROTEIN.

You have now found out that the Torula; or yeastcell, is a plant and not an animal ; the next question is, What kind of a plant is it? Mostly all plants need the sun, but the yeast-plant grows as well in the dark as in the light. Plants that need the light are always green; they take in that poisonous gas, CARBONIC ACID, and give off oxyGEN; but the ToRula has no green color, and it takes in OXYGEN and gives off so much CARBONIC ACID, that it is dangerous for people to walk over dis-

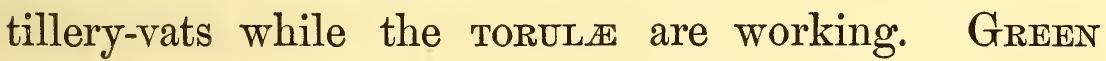
PLANTS cannot live without this CARBONIC ACID, but it poisons human beings. Those plants which give off CARBONIC ACID, grow in the dark, and are not green, are called FUNGI. The mushrooms and toadstools are FUNGI.

Now you will probably wish to know where the first TORULA came from-the great, great old GRANDMOTHER Torula of all. Nobody knows; we can only say God made it; how he made it, no one can tell. Chemists know that it contains so much CARBON, HYDROGEN, OXYGEN, and NITROGEN, and a few other things; but 
they cannot put these same things together again and make a ToRula; so, if you ask me what life is, I cannot tell you. Now, let us see how many things you have learned about yeast: First, that it is alive; second, that it is a plant; third, that it is a Fungus.

And now, perhaps, you understand what my buckwheat-cakes had to do with Science. 


\section{CHAPTER II}

THE GRE E PLANT.

All about the Chemists, Carpenters, Boatmen, and Ship-builders, that the Boys and Girls found working in the Old Rain-water Trough, and upon the Old Palings and Stone-Walls.

UNDER the low eaves at the back of the house was a long, deep wooden trough for catching the rain that fell on the roof. The inside of it was all lined with a beautiful green, velvety mould; and, when there had been no rain for some time, the water, too, would turn a greenish color. We used to catch our little downy yellow ducks and put them in the trough to see them swim, and often they would break off and eat the green mould with their curious shovel-bills. What this queer green stuff was, and how it came there, was another great mystery to us children. John declared it came down in the rain, just as the angle-worms that he used for fish-bait. Dick thought the fairies made it on purpose for the ducks. I must tell you that little ducks were Dick's delight; so he thought every thing was 
made for them. Let us see if either of the boys guessed the truth.

You probably have no trough in which you can find this mould; but there is plenty. of it on old palings, stone-walls, and trunks of trees. That which grows on the top of old rain-water is a little different, and I will tell you of this difference by-and-by. Carefully scrape off a little of this mud or mould, and look at it under the microscope. You will find little bodies which look something like the yeast-plants - TORUL $\mathbb{E}$; but you will see at once one great difference-these have color. Some are green, some are red, and others are red in the middle and green at the border (Figs. 17-20).

Fig. 17.

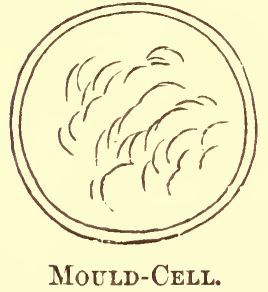

FIG. 18.

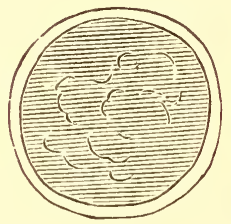

Green MouldCELL.
FIG. 19.

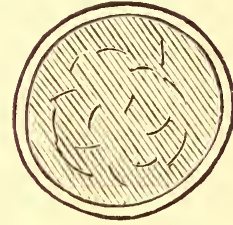

Mould-Cell with Red ('ENTre.
FIG. 20.

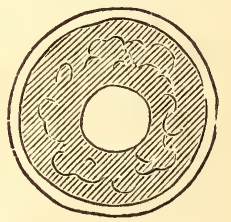

Red Centre And GreEN Border.

You will notice that this coloring is all inside the bag, and not in the wall of the bag itself, and sometimes, not often, you can see it in the form of little grains. Some of these bags or cells are about the size of the yeastplants, most of them are much larger, and nearly all of them have a round shape. The cell is made quite like 
the yeast-cell (Fig. 21); it has a woody or CELLulose sac, cell-jelly, or PRotoplasm, within the sac, sometimes a thin space, VACUOLE, and sometimes a little round

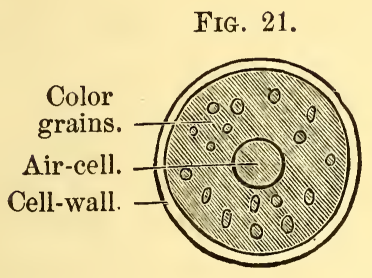

FIG. 22.

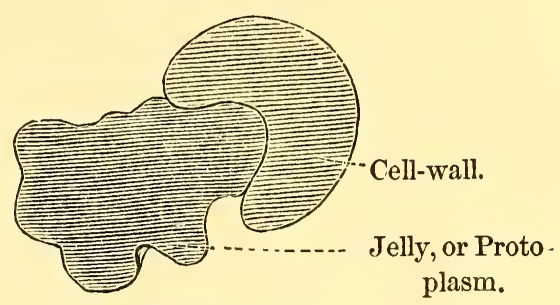

Broken Cell.

spot which looks like a kernel, or nucleus. If you press the cells lightly, the little sacs will burst, and the jelly-like рRоторlasm will flow out (Fig. 22). You can also color the cells with magenta, as you did the yeast or TORULж; but, if you color them with iodine instead of magenta, you will notice that some of the jelly or protoplasm gets blue. Now, iodine turns starch blue; so it may be there are some starch-grains in these cells, but we do not know positively. These cells, too, like the yeast-cells, have an odd name of their own-PRoTococcus. It means-first berry. Perhaps this name was given because these cells look like berries. I think you can remember it, because you have learned other names, which are just as long and hard, such as Yang-tse-Kiang and Brahmapootra; besides, you see protococcus almost every day, while probably none of you have ever 
seen the rivers of China and India. I think now you are anxious to know about your PRотососcus, or first berry, what I wanted to know about the mould in the old trough. What makes it look green? You are wondering why it is not white, like the rondes. This color comes from little grains, in the jelly, or PRoToPlasm, called chlorophyl. They are always found in plants which grow in the sunlight. The word chloroPIYL means green leaf. But the CHLOROPHYL of plants is not always green, as you see in the PRotococcusmould-it is sometimes red, and is found in the stem as well as in the leaf. But it was first discovered in the leaf, hence its name, green leaf, which is so very easy, it well help you to remember the long Greek namechlorophyl. All the plants which contain these colorgrains are called Green plants. You remember, the colorless plants are called Fungr. It is found that GREEN PLANTs must have the sunlight, whereas FUnGI, such as toadstools, grow in the dark. But what is the good of this dye-stuff, or chlorophy ; is it of any use, or is it there just to make the plant look pretty? It is of great use. Each grain is a very clever little chemist that works in the cell, which is his workshop, or LABORATORY, and the sunlight is the fire by which he heats his CRUCIBLE, or melting-pot. Into this CRUCIBLE he puts the poison-gas, CARBONIC ACID, that he gets from the air, and 
melts it up into CARBON and OXYGEN, keeps the CARBON to feed upon, and gives back the OXYGEN to the air again. Thus he works from sunrise to sunset; his hours are regulated by the sun instead of Congress and Parliament. You never hear of an "eight-hour movement" or a "strike" among these "colored" laborers. As șoon as the sun goes down, they go to bed like honest workmen. During the night, while the chloropHyLworkers are asleep; the PRoTоcoccus-cells give out CARBONIC ACID, and take in OXYGEN just like the TORULAcells. Hence, you see, to have growing plants in your room is healthy in the daytime, but not at night. Recent investigations would go to prove that the breathing of plants is similar to that of animals, during both day and night-that the breaking up of CARBONIC ACID, using the CARBON and giving off OXYGEN, is DIGESTION and not RESPIRATION. It has its seat in the CHLOROPHYL, and is active in the sunlight; while the RESPIRATION, the breathing in of OXYGEN and the breathing out of CARBONIC ACID, has its seat in the PROTEIN, and is active at all times.

You can, if you look long and carefully, see how the PRoтососсUs or mould-cells grow, not like the yeastcells, by giving out little buds around the edge, though . they do once in a while grow in this way, but mostly always the cell begins, like a little carpenter, to make a 
partition-wall right through the middle of the old house (Fig. 23), and, when this wall is quite finished, the two halves move away from each other, and the carpenter

FIG. 23.

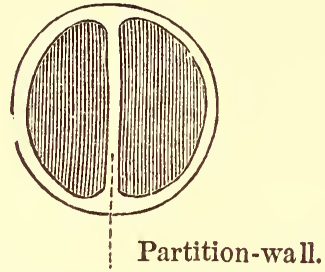

"Fission" of the Cell.
FIG. 24.

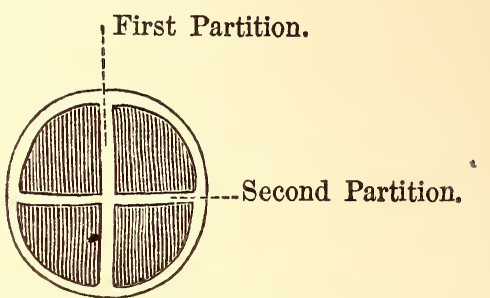

One Cell divided into Four.

rounds off the sides and thus makes two new houses out of the old one. Sometimes they build two partitions (Fig. 24), and instead of two houses there are four. What ingenious workers they are, thus to make four new houses out of one old one! They work so fast, too! The Chicago builders worked at the rate of one house an hour after the "great fire," but the рвотоcoccus-builders can even outdo Chicago, for they have been known to build-one hundred thousand houses per minute, and that, too, in the winter-time when the ground was all covered with snow! The RED PRoTococcus, sometimes called "red snow," which is found in the arctic regions and among the Alps, will cover hundreds of acres of ground with its little red roofs in almost "no time." There are many curious stories told about this red snow. Ancient ignorance thought it was 
blood which was sprinkled down from heaven as a warning for sins, and it caused as much terror as comets and eclipses, whereas it is an innocent pretty little plant. There is also a GREEN PRoTоcoccus which flourishes in the snow, and is called the "GREen-snow" plant. The red and the green snow plants do not grow just in the same way as the PRoтоcoccus of the trough or paling. The snow-carpenters divide the old house into a whole lot of little rooms (Fig. 25), then they burst the old

FIG. 25.

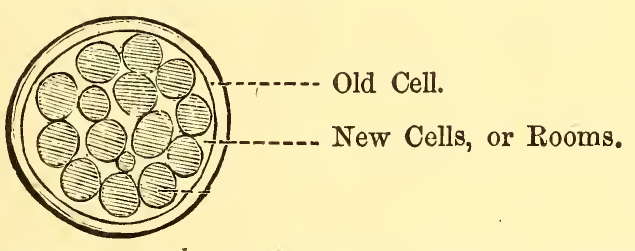

Snow-Carpenters inviding the Old House into New Rooms by Cleavage.

wall, and each one of these little rooms becomes a separate mansion, and goes on doing the same thing for itself. This process of growing or building is called Cleavage; the first kind is called fission, while the kind of growth of the yeast-plant is called BuDDING. You remember, I spoke of a difference between the mould on the sides and that in the water of the old - trough. You see that the cells you are looking at do not move about under the microscope, but remain quietly where you place them. But, if you examine 
some of the PRoтососCUs that grows in old water, you will see the cells sculling about very fast like so many little boats (Fig. 26). If your eyes and microscope are

FIG. 26.

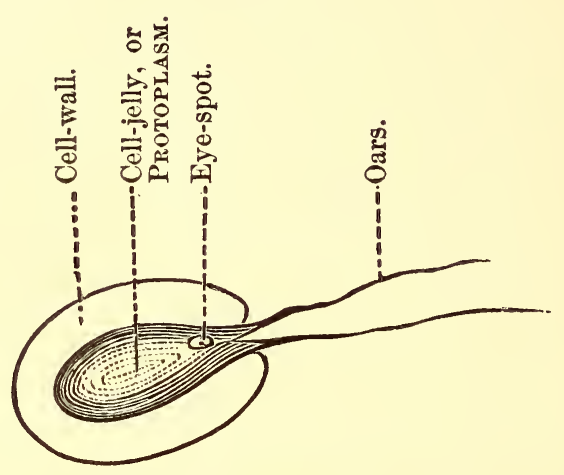

Boat, or Pear-shaped Cell.

very good, you can see the two tiny oars by which the little boatman guides his craft. There seem to be two kinds of boats-one small, green, and shaped like a pear; the others are larger, and more like the carpenters' houses. The pear-shaped boats have often a little red window, or port-hole, which is called the "eyespot" (Fig. 27). If you watch long and carefully, you can sometimes see the boatman pull in his oars as if to rest (Fig. 28), and then, if you disturb or shake the water and put it in the sun, out go the oars again, running faster than ever. They move at the rate of twelve times a second; while a watch is making one tick, they 
make twelve strokes. If you put in a drop of iodine, it will stain the little fellows, and kill them, too; then

Fig. 27.

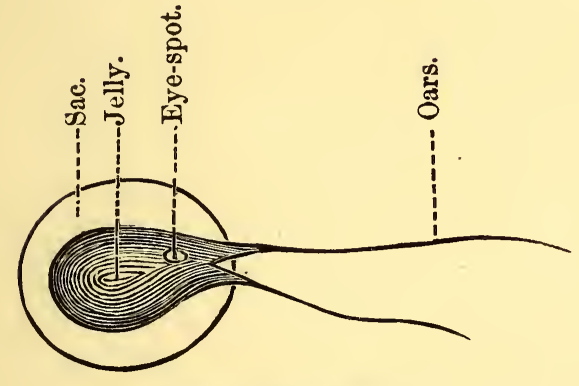

Protococcus-Boats.
Fig. 28.

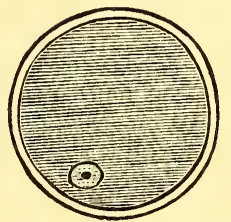

Protococcus, or Berry-BoAt, with OARS PULLED IN.

you can see how they are made. The pear-shaped cells do not have a tough cellulose sac (Fig. 29); these in-

Frg. 29.

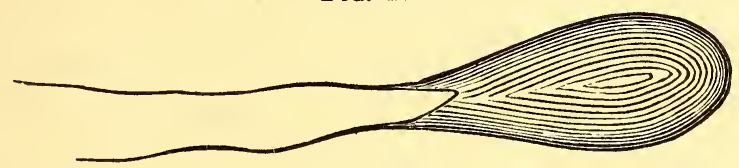

Pear-shaped Cell without a Sac, or the Boatman without a Boat.

dependent little sailors seem to jump out of the boats entirely, and go swimming about quite naked in the water. Perhaps they are recruiting their health by sea-bathing. After they have thus bathed to their hearts' content, they retire quietly to the sands, and dress themselves again; that is, each one builds about himself a new wall, or boat, in which he rests till he 
wants another dip. When they lay aside this cell-wall, or boat, they are in the same condition as animal-cells. You remember, I gave the sac as one of the differences between vegetables and animals. It would be strange if these little creatures, like the fairies, could turn into plants or animals as they please. The larger kind try to be more respectable, and stay in their boats in a dignified and proper manner. After they are killed by the iodine, you can see where the little oars are pushed through the row-locks in the sides of the boat. These oars are called CILIA, a Latin word which means eyelashes. When the little sailors are getting tired, and just before they die, you can see these eyelash oars very well, they move so slowly; but, when the sailors are "strong," and the day is sunny, the oars go so fast you cannot see them. No Oxford or Columbia crew can begin to pull with these PRotococcus boatmen. They are not only very good rowers, but they are good builders, too; for you often see them breaking up the old boats by cleavage and Fission, just as the carpenters break up the old houses. The mould that grows on old wood and stones is called sTILL PROTOCOCCUs; that which moves about by oars is called MOvING PROTOcoccus. Thus we have followed our quaint little friend, the рвотососсus, through all his trades: chemist, carpenter, boatman, and ship-builder. Now, I am sure, 
you will never pass by an old fence or a pool of green water without thinking of the wonderful little artisans that are working there. When I watched the ducks swimming in the old trough, little did I think of the noiseless hands and hammers that were building up those green walls, or of the unseen and unnumbered fleet of boats sculling through the water. 


\section{CHAPTER III.}

THE FLOWERING PLANT.

Or the Boys and Girls learning how to "know Beans," assisted by "Jack the Giant-Killer."

I REMEMBER something about a story called " Jack and the Beanstalk," "Jack the Giant-Killer," or some such name. At least, I know there were a bean, a boy, and a giant, in the story, and that the bean and the boy together caused the death of the giant, and I think the old giant's name was Ignorance. We will make believe it was, anyway, for it is time the old monster were dead; he has always kept boys and girls from learning any thing, especially about science; and now that he is out of our way, I want to tell you how much there is for you to learn about the bean.

The first thing that Jack did was to plant a bean, and that is just what I want you to do; but before you put it into the ground, you must take a good look at it inside and out. A bean is a very common thing; everybody knows it, and yet nobody really "knows beans." 
First you will notice its shape-all are not the samesome are flat, others almost round, and others kidneyshaped. This is the common white bean, which is longer than it is broad, with rounded surface (Fig. 30).

Fig. 30.

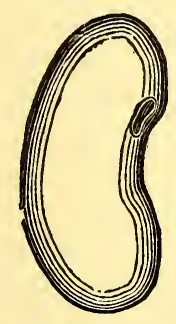

White BeAN.
Fig. 31.

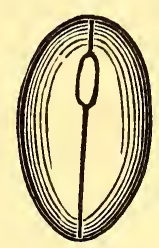

Bean turned edgewise, showing Little Gate.

One side is slightly curved inward like a kidney, and at one end is a long black scar called the HILUM ; it shows where the bean was fastened to the pod. Toward the dented side of the bean, and quite close to the black scar, is a little opening called the MICROPYLE (Fig. 31), which means little gate, and it leads into the inside of the bean-seed. In order to see the other parts well, it is best to soak a few beans in a little water to soften them. First there is a white outer covering. or greatcoat, which is very tough, almost like leather, and this is called the TESTA, which means shell or cover; under this is a thick, white substance, which, by pressing a little, splits lengthwise into two equal halves (Fig. 32). These are called COTYLEDons, because they form a little cup to 
hold something. This something you will find at the inner curve or dent of the bean-a little yellowish-white thing, that looks like a worm coiled up (Fig. 32). This is the germ, the part which grows up and makes the bean.

FIG. 32.
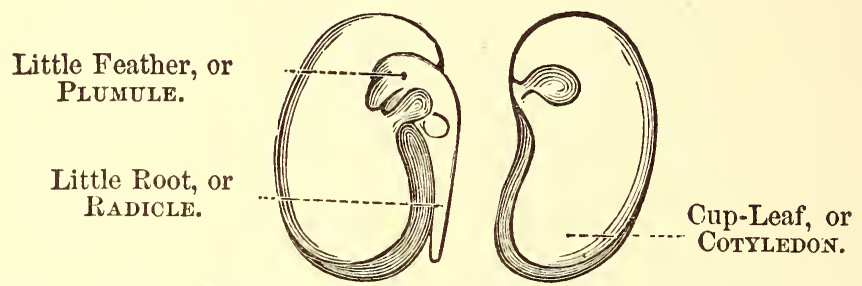

The Two Leates whil form the Cup, or Cotyledon, of the Bean.

It must be very important, because Nature has taken such pains to wrap it up in a great-coat, and give it such a nice bed to lie in. I heard of some people who threw away a whole crop of beans, because they thought these little germs were worms. That must have been before the old giant Ignorance was killed. The germs are really worth looking at, they are so prettily made; the top curls inward, and looks like a little feather (Fig. 32); so it is called the "PLunule," which means little feather. The bottom is pointed like a little root, and is called the RADICLE, that is, little root. This is all you can see till the bean begins to grow. Jack put his bean into the ground, but if you put yours into a glass of water it will grow quite as well. Plants will 
grow in water, if you give them the salts or mineral matters they find in the earth. The ground is the best soil for plants, because it already contains the fuod they need; besides, it forms a firm foundation for the roots. First, the bean begins to swell out and get larger, from the water which it takes in, and if you watch the MICROPYLE, or little gate, carefully, you will see the pointed end of the RADICLE, or little root, pushing downward through this little gate. It is very curious that the root never points upward; if you plant a seed with the gate upward, the root will always turn down as soon as it gets out. The end is made pointed, no doubt, so as to force or bore its way through the hard ground. When people plant seeds, they make the ground soft like powder, so that the little tender roots shall not have such a hard time of it at first. The bean keeps on drinking and drinking more than one and one-half time its weight of water, till finally its great-coat gets so tight that it bursts and falls off, then the two coryLeDons, or cups, spread apart (Fig. 33), and the Plumule, or little feather, appears, lifting its head above the ground or water, and puts out two tiny leaves. If you measure the germ now from the end of the leaf to the end of the RADICLE, or little root, you will find it much longer and thicker than it was at first; it has grown very fast, and you know nothing can grow without 
food. Now, where did the germ get its food? For such a little creature, it is the best manager I know of : it seems to understand that it is going on a long and dangerous journey, so it packs up plenty of food in its

Fig. 33.

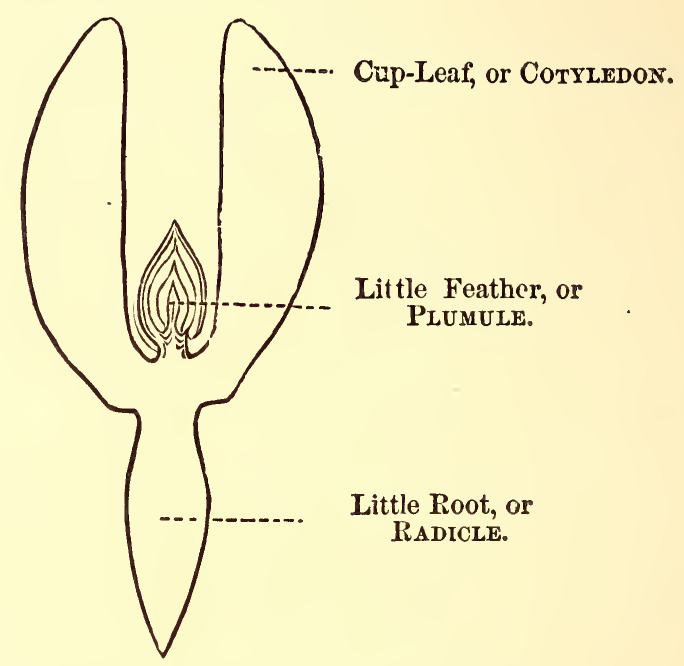

The Bean after it has bUrst its Shell, or Testa.

two cups, and then nestles down to sleep between them, all nice and warm, never bothering itself about any thing till it begins to feel the water and air creeping in around its bed. This is the sign for it to be up and doing, and, like an experienced traveler, it first fortifies itself by a good breakfast. The cups, or сотүLEDons, are packed full of starch, but the germ will not eat starch, it prefers sugar. Why, then, did it not pack up sugar instead of starch for its journey? Because 
the starch will keep better (it is said to keep for centuries), and it takes up less room. Here again our little friend proves itself a good traveler; it does not carry much luggage. It is a great deal easier to turn the starch into sugar as it is needed than it is to carry

Fig. 34.

Bud at Top of Plumule.

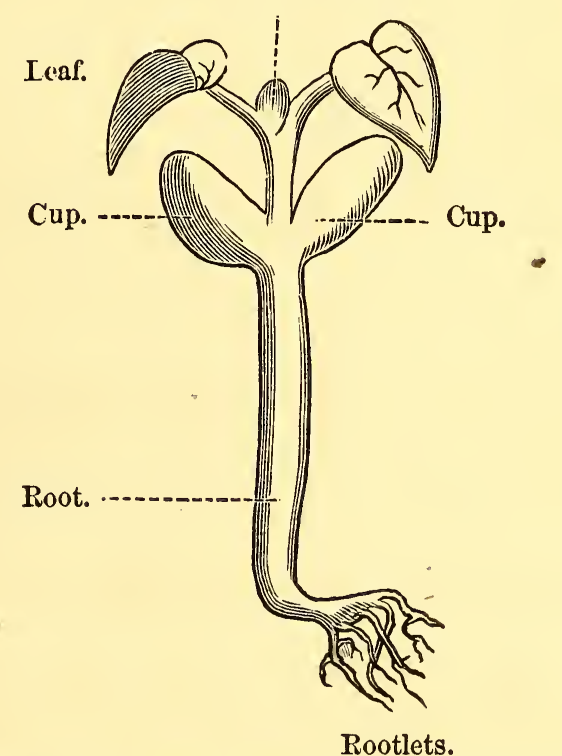

Tue Little Plume growing dp into Stem and Leaves, and the Radicle growING DOWN INTO RoOT AND Rootlets.

the sugar ready made. The bean, like a boy, has a "sweet tooth," and it lives on sugar till it gets large enough and strong enough to find other things to eat in the ground or water. The young plant, thus feeding on the food in the seed-leaves or COTYLEDons, is another 
proof that plants do not always make their PRoteIN out of the raw material. The plant begins its life by using food prepared for it by its parent. Dr. Hooker suggests that plants, like the Venus fly-trap, simply keep up this habit of childhood, and keep on eating readymade food throughout their whole life. Between the first-opened leaves of the PLUMULE, or little feather, you can see a tiny bud (Fig. 34) or growing point, which rapidly lifts itself up into the air and becomes the stem, giving off buds to form new leaves. The points of the stem where the leaves come out are called Nones (from a Latin word, which means a knot or swelling), and the spaces between the NoDEs are called INTERNoDEs, which means between knots (Fig. 35). Each NoDE, or knot, gives off one leaf, and the leaves are said to alternate, because they are placed on opposite sides of the stem, but not opposite each other (Fig. 35). Between the leaf and the stem other buds appear, and these produce new stems or branches. Some of the buds, instead of turning into leaves, open out into flowers. The part of the young plant which lies below the ground is called the root; it tapers to a point, contains no dyestuff, or chloropiry, and, instead of buds, little tiny roots called "ROoTLETs" grow out from its sides (Fig. 35). It is through these RootuEts that the plant is fed, but how does the food get in? The outside is quite hard, 
and you can see no openings, but each RootLET ends in a soft, little, spongy knob called a spongroue, which

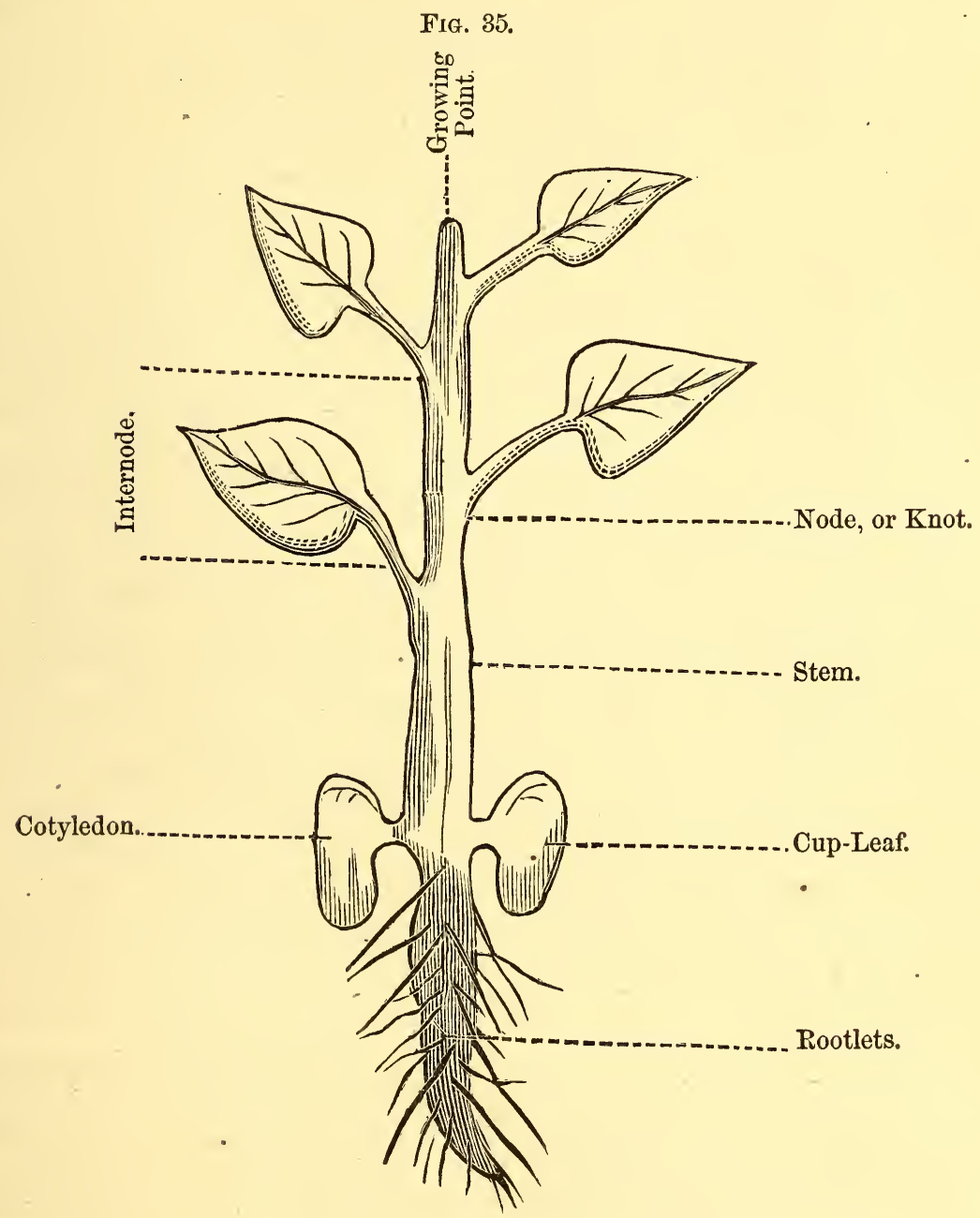

Root.

sucks the juices from the ground, just as a sponge drinks up water. You can see the spongioles, or little sponges, 
very well in the duck-weed (Fig. 36), a tiny plant which floats on the surface of ponds. The food which they take up is made of water, Ammonia, or hartshorn, and mineral matters; all the different parts of the

FIG. 36.

Leaves that float on Surface of Water.
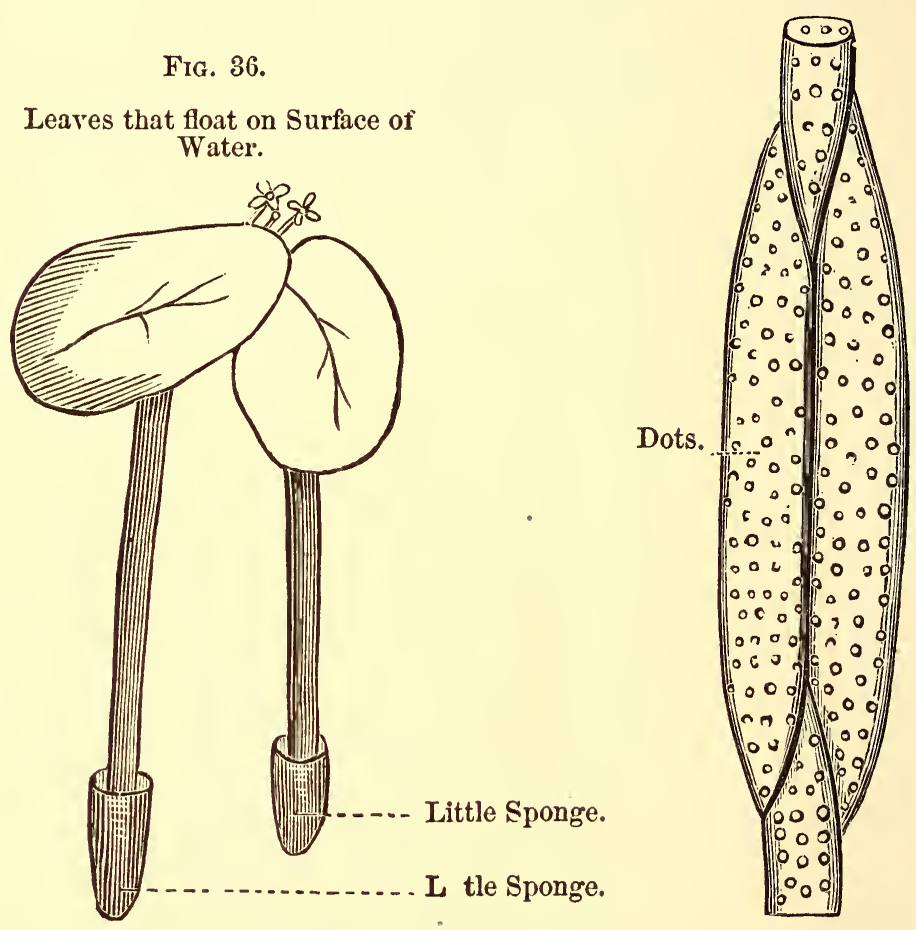

DUCK-WeED.

Dotted Ducts, or Tubes, that Carry JUICes to the Leaves.

plant, its leaves and flowers, are made by these simple things. The little sponges, or spongroles, have such dainty appetites, they know just what to sip, and if they cannot get it close at hand they search till they find 
it. The fluid passes through the little mouths of the sponges into small tubes, or DUCTs, which carry it up the root and stem to the leaves. If you cut a very, very thin slice lengthwise of the stem, and put it under the microscope, you will see these vessels plainly, because

Fig. 38.

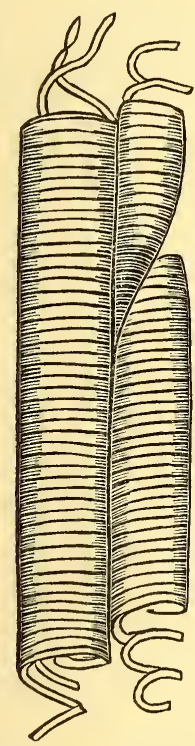

FIG. 39.

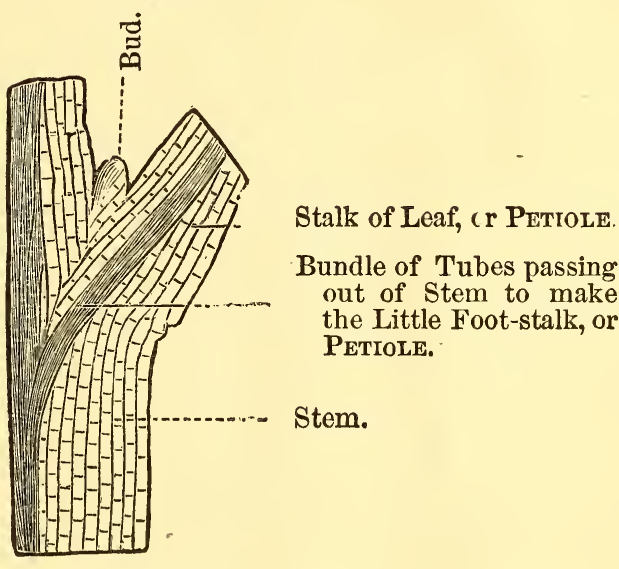

AIR TUBES, SHOWING THE

Comled Springs.

their walls are all dotted (Fig. 37). There are other tubes in the stem, very curiously made, for carrying air. They seem to be filled with little coiled springs, which keep the sides from coming together, just as you may have noticed India-rubber gas-tubing, which has coiled wire inside to keep the tube open (Fig. 38). Some of 
these tubes unite in a bundle, and leave the stem at the NODEs, or knots, and they form what is called the "PETIOLE," or "little foot-stalk," of the leaf (Fig. 39). Again, the tubes of the foot-stalk pass off at the sides,

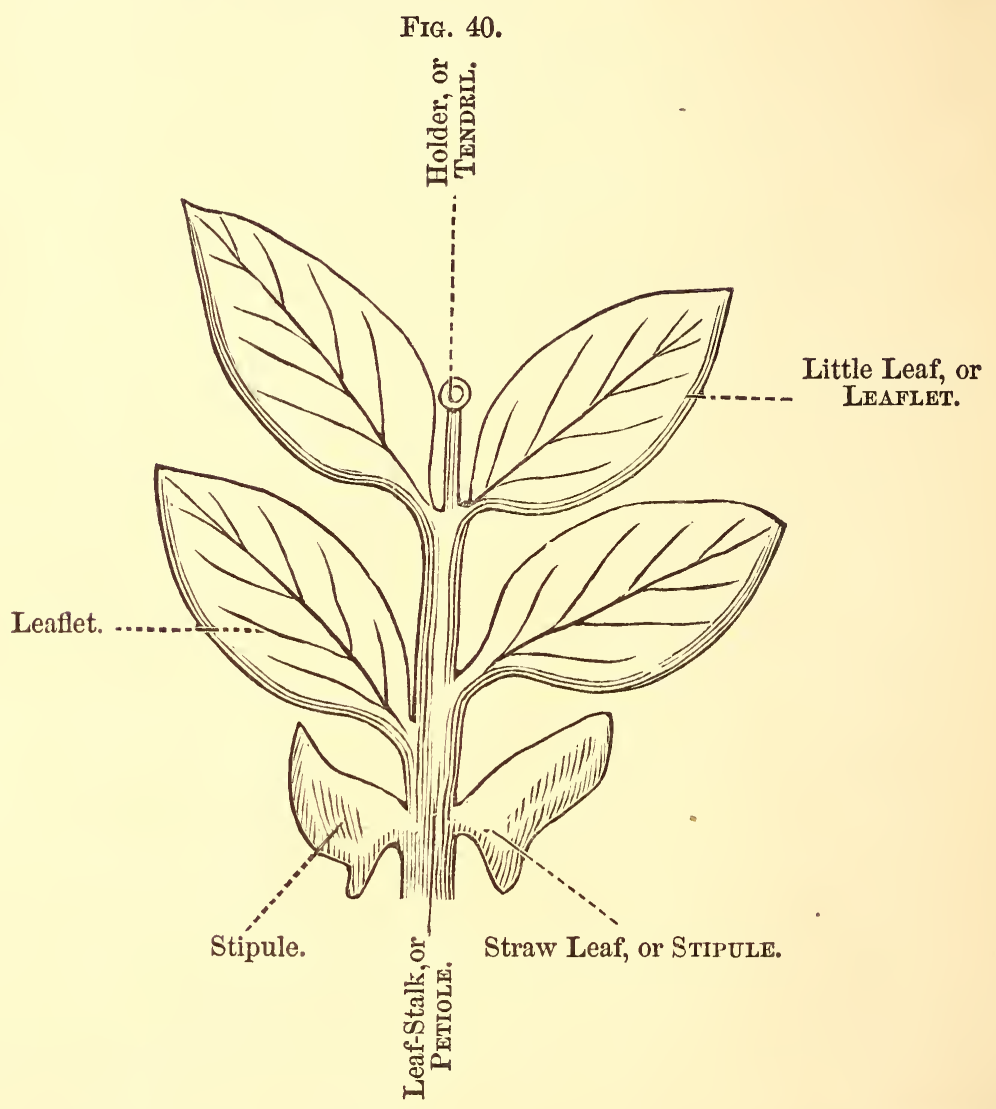

and spread themselves out into a net-work, which forms a skeleton or framework to support the leaf. Each PETIoLe, or foot-stalk, gives off from four to six of those little leaves, or Leaflets (Fig. 40), but at the end 
of the stalk there is no LEAFLET, but instead a curious thread-like body (Fig. 40), which in some beans grows very. long and helps them to climb. This thread is called a TENDRIL, or holder. At the base of the leafstalk, at each side, is a leaf-like part called a sTipuLE (Fig. 40). The two stipules protect the leaf-bud before it opens. They usually wither away and look like straws, hence their name; but in the pea they are very large, much larger than the LEAFLETS. If you look on

Fig. 41.

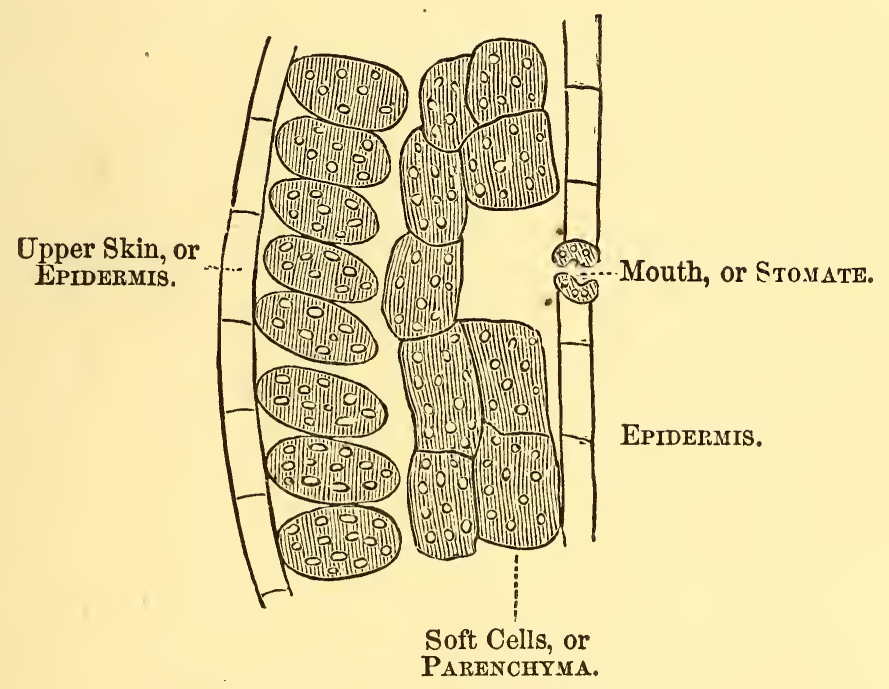

Slice of Leaf under Microscope.

the under side of the LEAFLETS, you will see a central ridge much larger than the others, and this is called the MIDRIB, or backbone, of the leaf. The branches going off from its sides are called verss, and these and the 
MIDRIB are called the skELEToN of the leaf. Over this skeleton or framework is spread the soft part of the leaf, the PARENCHYMa (Fig. 41), which is made of small green cells, very like those which form the PRотососcus or green mould. These soft, green cells, like the other parts of the plant, are protected by a thin skin (Fig. 41) called EPIDERMIs, which means upper skin. If you

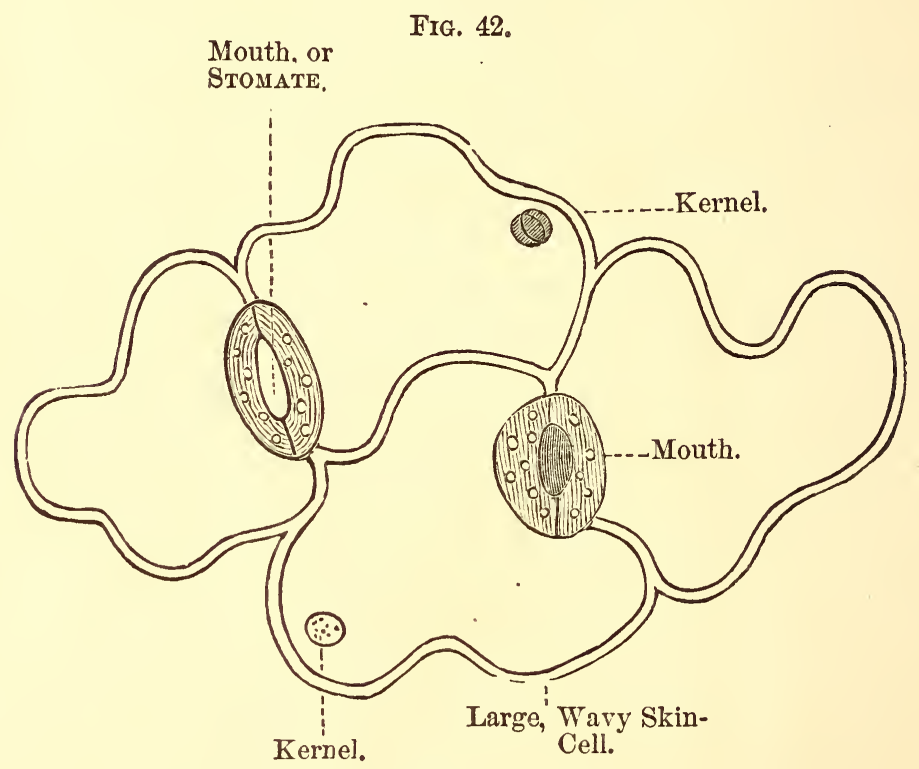

A Strip of tue Skin, or Epidermis, of Leaf.

strip off a piece of this thin outer skin, and put it under the microscope, you will find that the cells contain no color-grains, or chlorophyL. They are very large, with wavy edges, which fit with one another (Fig. 42). Here and there in the thin outer skin, es- 
pecially on the under side of the leaf, are little openings (Fig. 42) called stomates, which means mouths; each mouth has an upper and lower lip, formed of two

Fig. 43.

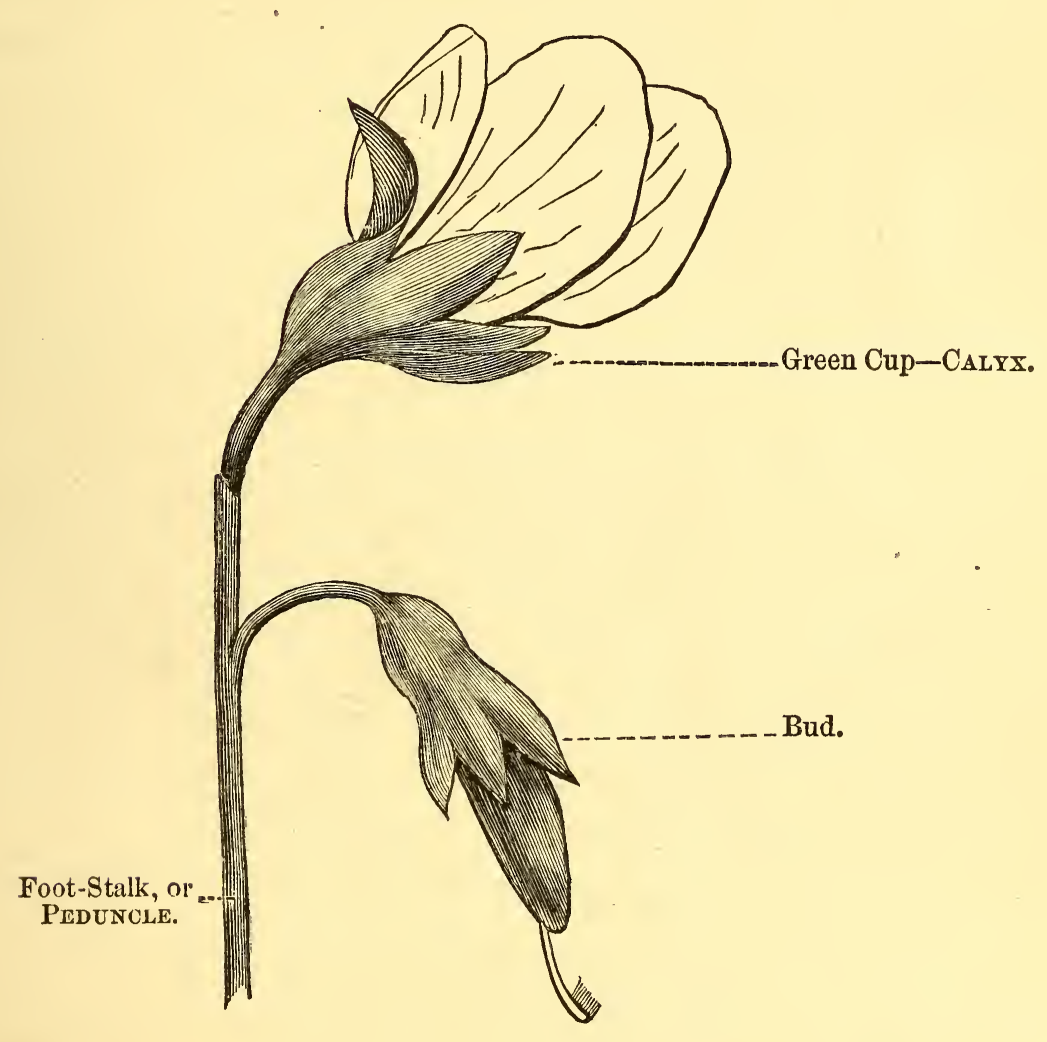

kidney-shaped cells containing CHLOROPHYL, and they open and close to allow CARBONIC ACID from the air to pass in, and the oxyGEN and water to pass out. The little sponges at the roots drink up more water than the 
plant keeps, so this extra water passes off through the stomates, or little mouths, of the leaves. Each little green cell of the leaf is like the LABORATORY of the PRoTococcus, where the chemist splits the CARBonIC ACID into CARBON and OXYGEN, keeping the CARBON, but sending out the oxYGEN through the mouths, or sToMATES. This passage of gases, fluids, and minerals, through and into the plant, is what is meant by the breathing and digestion of plants. Now we will take a look at the flower ; it too has a foot-stalk, called a PEDUNCLE, or little foot, by which it is fastened to the stem (Fig. 43).

FIG. 44.

The Five Leaves, or SePals, of Cup.

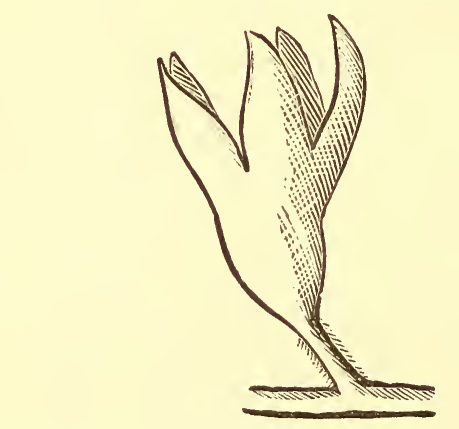

The Flower-Cup, or Calyx, of Bean.

Counting from the outside of the flower inward, you will come to four different-sets of things, arranged in circles, or whorls. First, outside is a pretty green cup with five points on its edge (Fig. 44); this cup is called 
the calrx, which means cup, and the five points show that it is made up of five leaves joined together by their edges: each leaf is called a sEPAL. Within this pointed cup is the showy, scented part of the flower called the conolla, which means little crown; it is the crowning part of the flower (Fig. 45). At first it looks

FIG. 45.

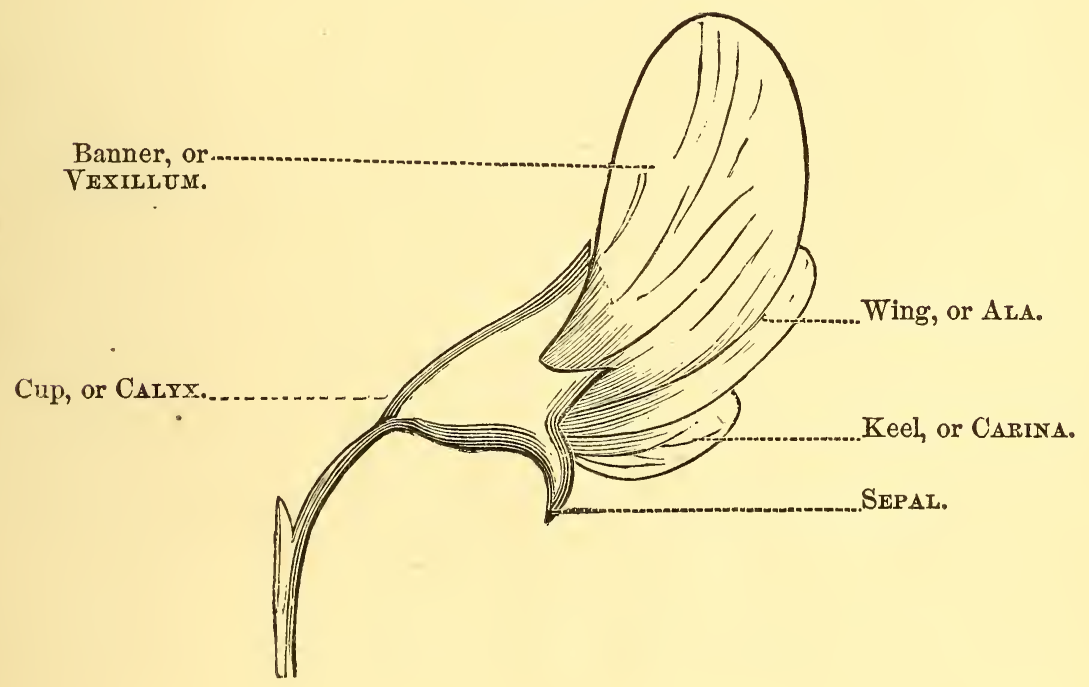

as if you could not understand how this crown is made, but, if you take pains and do not get out of patience, it will come out all nicely into five pieces, and each piece is called a PETAL (from the Greek petalon, which means a leaf). On the upper or Donsal side of the flower, next the stem, is one large PETAL or crown-leaf folded over the rest, with its top all spread out (Fig. 46). It 
has a long, hard name, vexillum, which you can easily remember because it means flag. The bean is very patriotic, it carries its banner with it wherever it goes. I suppose the English boys call this flag the "Union Jack;"

FIG. 46.

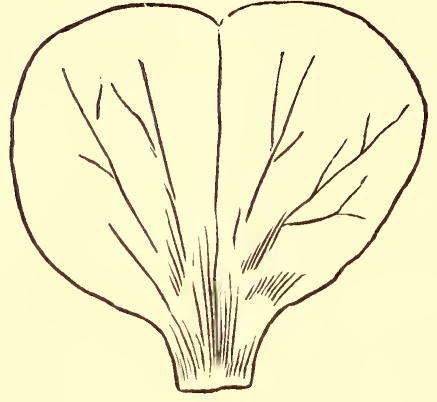

Flag, or Vexillugu, of Bean.
FIG. 47.

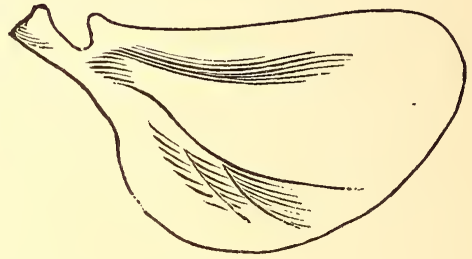

Wing, or Ala, of Bean.

you, perhaps, will call yours the "Stars and Stripes," but I never heard of beans carrying their banners into battle. The sides of the crown are made of two leaves, called the ALE, or wings (Fig. 47). They are formed somewhat like the wings of birds. The next two coRoLLA, or crown-leaves, are odd shaped, and look at first sight like one, because they are so closely joined. The two together look quite like the keel or bottom of a ship, so they are called the carina, or keel (Fig. 48). This CORoLLA, or crown of the flower, is one of the queerest in the world; indeed, it looks more like a butterfly than a flower. Inside the conolla, or crown, we come to the 
third whorl, made up of ten little stalks, with knobs at their ends like walking-sticks (Fig. 49). These are the sTAMENs, and five of them are shorter than the others, as if two rows of five each were joined in one. The

FIG. 49.

Frg. 48.

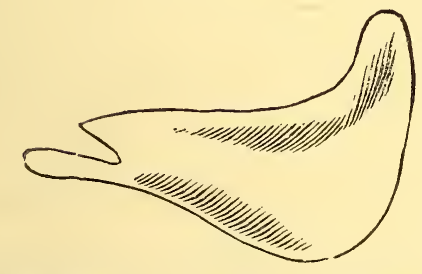

The Keel, or Carina, of Bran.

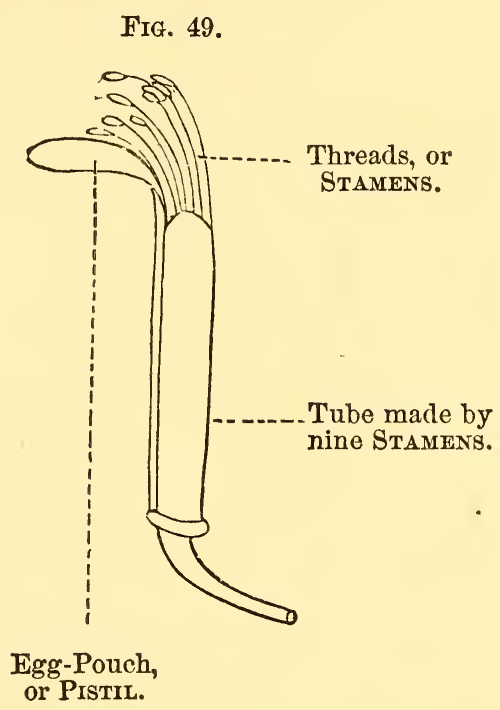

word stAMEN means a thread. The slender stalk of the STAMEN is called the FILAMENT, or fine thread, and the knob on the end is the ANTHer (Fig. 50) (from the Greek anthos, a flower). The ANTHER, or knob, is such a curious little thing; it is divided into four chambers (Fig. 51), and each is filled with fine dust called POLLEN, because it is so like very fine flour (Fig. 52). I dare say you have wiped off some of this flour when you have put your noses into the cups of lilies. The bees carry some of this flour home on their hind-legs, and bake it 
into bee-bread, which they feed upon all winter. I don't know of any thing prettier under the microscope than the POLLEN of different kinds of flowers. As soon as the flour becomes dry enough, these little knobs or

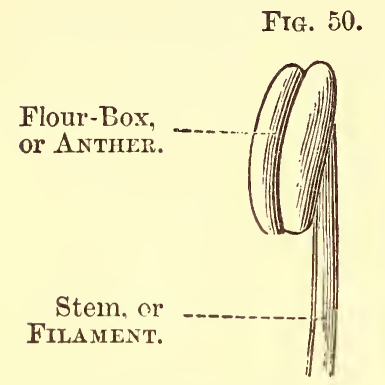

Stamen, with its Flour- Flour-Box, or Anther, cut Box, or ANTHER.

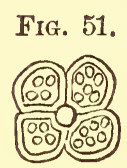

ACross, SHOWING Four Chambers full of Flour, or Pollen.
Frg. 52.

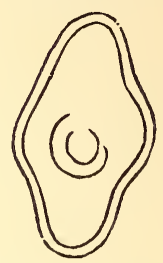

FloUR, OR POLLEN - Grain CUT ACROSS-SHOWING THE OUTER COATS AND THE SUBSTANCE INSIDE.

flour-boxes burst and let it all out. Why, we shall see presently. The Filaments, or stems, of nine of the sTAMENs all join together into one bundle or brotherhood, and form a nice little tube (Fig. 49); but one of them is a little "secessionist," he refuses to join the "union." Within this stem-tube is the fourth and last part of the flower, the PIsTIL, a long, green body, with a pointed end full of strong hairs standing up like the tuft from the head of an Indian chief (Fig. 53). The first time I ever told a certain little girl about the PIsTIL, she wanted to know if flowers could shoot with their pistols. She did not know any thing about spelling then. The word 
PIsTIL means pestle, or mortar. The flower-PISTIL is shaped somewhat like the druggist's pestle, or mortar.

Fig. 53.

Petal, or Flower-Leaf.

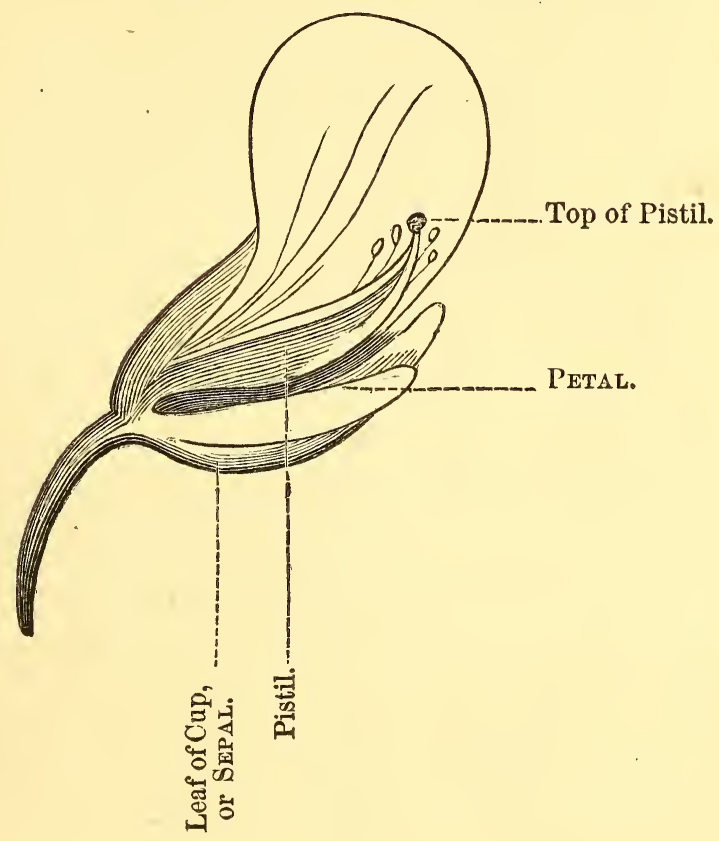

The long, green body (Fig. 54), which forms the lower part of the PIsTIL, holds the eggs or young seeds, and so it is named the ovary, or egg-bag. The top of the eggbag is drawn out into a curved, hollow tube (Fig. 54) called the styLE (which comes from the Latin stylos, a column), and is capped by a soft, sticky, hairy knob, called the stigms, or mark. If you slit open this OVARY, or egg-pouch, you will find the young seeds, or 
eggs, fastened to its sides by small cords (Fig. 55). These eggs are called ovules, that is, little eggs. Each

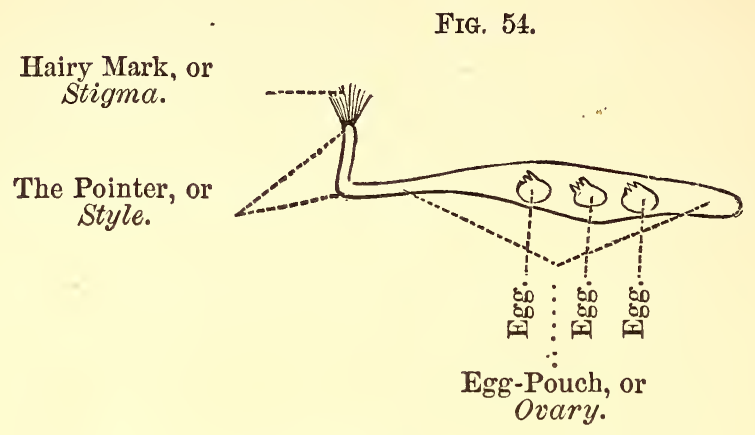

Pistil and all its Parts.

little egg is well protected by two coats (Fig. 56). In the centre of each egg lies a group of cells called the kernel, or Nucleus (Fig. 56); but this NUCLEUs of the

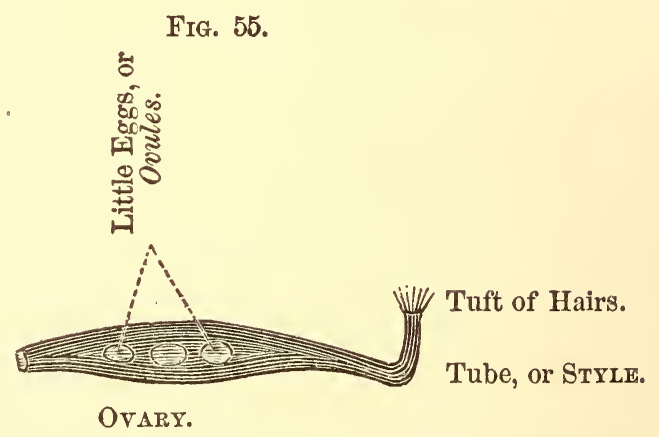

Pistil and its Three Parts-Stigma, Strle, and Orary.

seed is different from that of the Амळва and PRотососcus. The little gate, the micropyle, leads through the coats into the nucleus (Fig. 56). You recollect, I told 
you about the ANTHER, or powder-box, bursting, and the flour, or PoLLEN, coming out; well, some of this flour falls upon the little tuft of hairs at the top of the egg-

FiG. 56.

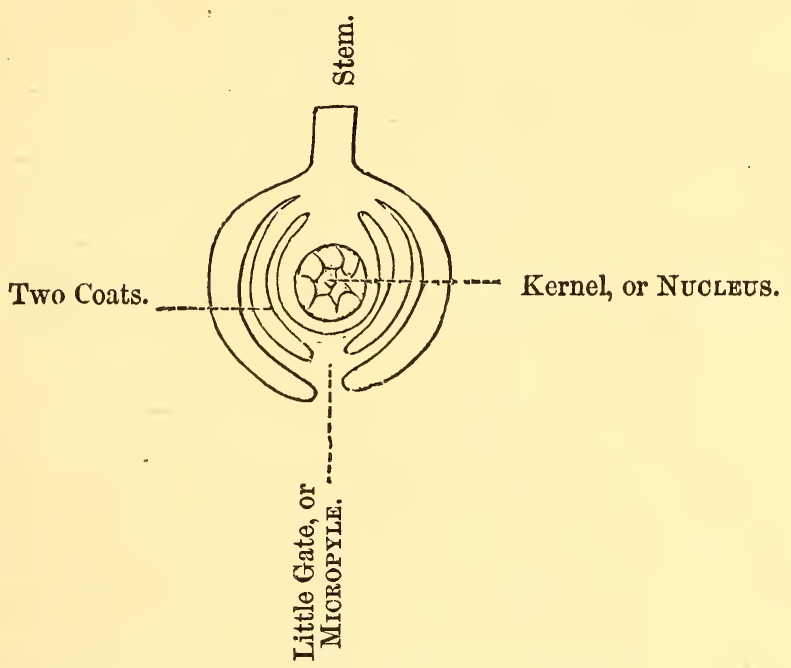

The Little EgG, or Ovule, and all its Parts.

pouch, but very often bees and other insects get some of it on their legs and backs, and, as they fly from flower to flower, it thus reaches the hairy knob, or stigma. Just at this time the stigma is covered by a sugary fluid, and is very sticky, so the flour cannot roll off; the tuft of hairs also helps to catch and hold it. This dust, or Pollen, loves sugar, and so we find it "sitting on the style" making itself quite at home, and drinking all the syrup that comes in its way. It takes in so much, that its great-coat bursts, and then it grows 
larger and pushes itself out in the form of a long tube (Fig. 57). This tube works its way down through the tube of the PIsTIL into the egg-bag, where it enters the

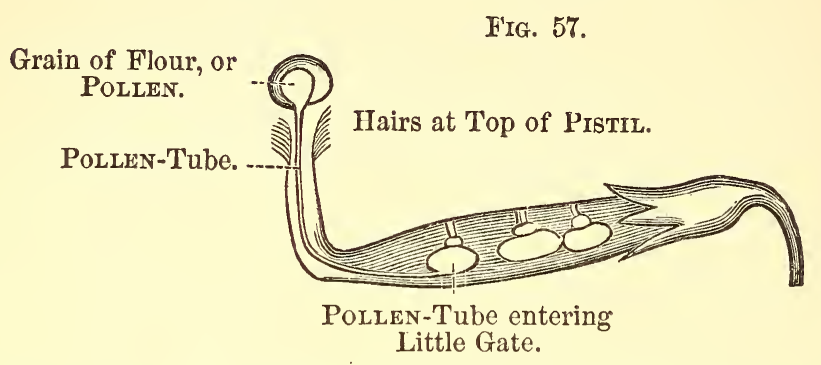

The Pollen from the Flour-Box, or Anther, finding its Way to the EgG, or Ovule, in the EgG-Pouch of the Pistil.

little gate of one of the eggs, and unites with the kernel, or NUCLEUs, that we found in the centre of each egg. After the Pollen-dust from the dust-boxes of the sTAMENs has thus united with the kernel of the egg, inside the egg-pouch of the PISTIL, the two together begin to grow, and form the little GERM that we found lying in the cup of the bean. And this is the way each young bean-plant is formed; some of the flour enters the little gate and unites with the kernel of the egg, and the two grow together into one little plant, or GERm. The OVARY, or egg-bag, still keeps on growing, and forms what is called the LEGUME, or pod, of the bean. The eggs, too, grow larger, and as soon as the pod is ripe it splits open, and inside of it you will find beans just like those you planted. 
And thus is finished the journey of the bean; here it lies safe and sound within its little cup, with the coTYLEDONs all packed ready for a tour when the weather gets bright and warm in the spring-time. Now, what kind of a plant is the bean? Not a fungus, because it is green like рвотососсus, and needs the sunshine, so it must be a GREEN PLANT; but it is different from PROTOcoccus, because it bears flowers, and the PRотососcus does not: hence, we must not only call it a GREEN PLANT, bUt a FLOWERING PLANT.

These are only a few of the many things there are to learn about a simple bean-stalk. Who would have thought that it took so much hard study just to "know beans?" 


\section{CHAPTER IV.}

THE HUMAN AND THE POND AMOEBAE.

What Wonders the Boys and Girls found in a Drop of Blood, and the Scum of Green Water; and how Blue-beard lost his Chance of becoming a Scientific Man.

Of course, you all know the story of Blue-beard; how he found out that poor Fatima had been to the closet where he murdered his wives, because the key was all stained with blood. Young folks have a strange fancy for "bloody stories," and they are mostly always afraid of blood, and so are a great many grown-up people. Now I am going to tell you not exactly a "bloody story," but a story about blood, and you need not be alarmed, for, before I finish, you will find there is nothing in blood to alarm any one, but a great deal that is useful, curious, and beautiful. Boys are always cutting their fingers or getting bloody noses, but you need not wait for such an occasion, nor need you turn Bluebeards in order to find some blood for examination. If you prick your finger ever so little with a needle and 
then squeeze out a drop of blood, you can see in it all that I shall describe. Placing this drop of blood under the microscope, you will find a whole cluster of little reddish-looking bodies (Fig. 58), and among these a FIG. 58.

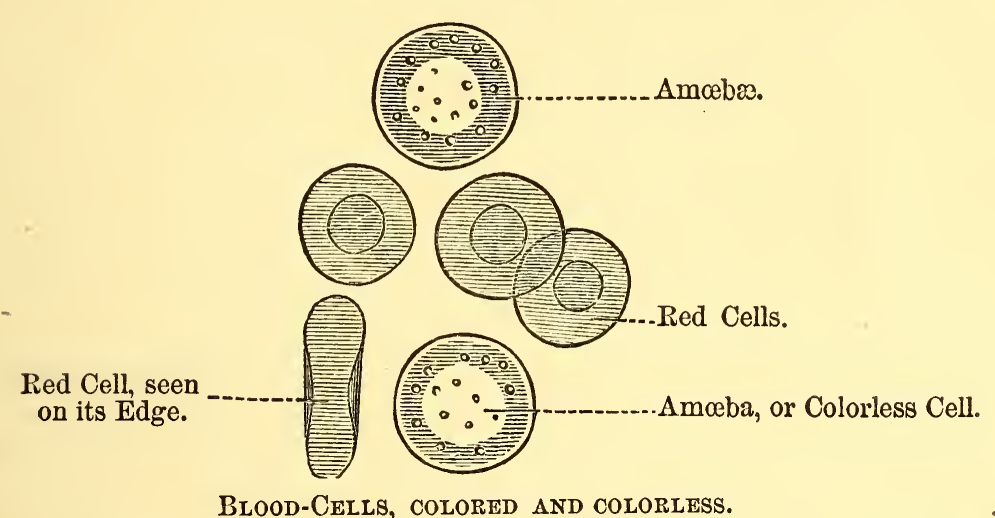

number of larger, clear or transparent bodies, which look like splashes of light-colored jelly (Fig. 58). It is about these jelly-like bodies I am going to tell you. If you keep your eye on one of them, you will see that it continually changes its form, and that it has a slow, crawling kind of motion. And, if you try to make a drawing of it on paper at different times, your picture will never be twice alike (Figs. 59, 60). It puts out something from one side which looks like a foot; then it will draw in this foot and put out another at the other side, as if trying to find a soft place to walk upon. Sometimes it puts out several of these at one time. 
This little jelly-splash appears to use its feet as we use ours to walk with, though you will see that it gets on quite slowly and awkwardly. Its foot is called a PSEU-

Frg. 59.

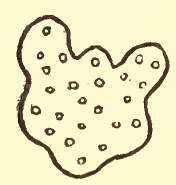

FIG. 60.

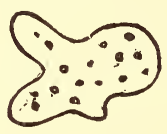

The Amgra, or Blood-Cell, changing its Fornd.

FIg. 61.

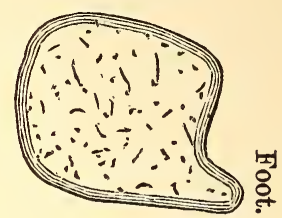

Dopodium (Fig. 61), which means false-foot. These little bodies have a very suitable name-Амсвв, and the word means changing. This name was given to them because, as you have seen, they are constantly changing their form. The АмळвА, or blood-cell, is larger than the ToRula, or yeast-cell, and not quite so large as the largest cell of the PRотососcus, or green mould. It is usually about $\frac{1}{2500}$ of an inch in breadth. It does not possess a tough, woody, or CELlulose sac, like the yeast-cells or the РRотосоccus-houses; it is more like the moving рвотосоccus-boatmen. Its wall is just the hardened outer layer of its own jelly, or PRoTOPLASM. It has no VACUOLE, or thin space; no eyespot; no CILIA; or eyelashes; and, when it is quite fresh and new, you cannot see any nUCLeus, or kernel; you really can see nothing but an odd-looking lump with here and there some little grains inside of it. If 
you give it a drop of weak vinegar, or ACETIC ACID, its GRANULES will disappear, and you can see the NUCLEUS, or kernel, in the centre (Figs. 62, 63); you may find

Fig. 62.

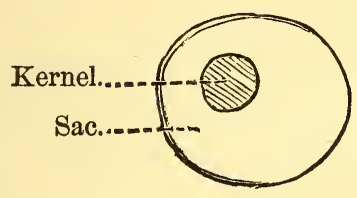

FIG. 63.

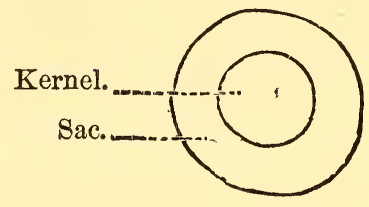

Cells cleared with Vinegar, so as to show the Nucleus.

it easily if you color the cell with magenta or weak iodine. This Nucleus seems to have something to do with forming of new cells, as we shall soon see.

Heat makes the AMCB $\mathbb{E}$ move much quicker; it is very interesting to watch them make their way among the colored cells, which lie all around them. Sometimes one of these crawling cells will clear a channel for itself right through a thick group of the yellowishred cells (Fig. 64). The first time I ever saw one moving in this way, I could not help thinking of the canals in Venice, where the gondoliers steer their gondolas close beside the houses, turning the corners so skillfully, never striking them; so this little gondolier of the blood went in and out, threading its way among the yellow cells which stood in rows like houses on either 
side of the channel. There is one great difference, though: in Venice the gondolier has nothing to do but row along the canals which are made for him; but the amœba-gondolier has to make his way as hẻ goes. No wonder you open your eyes. It is enough to open any

FIG. 64.

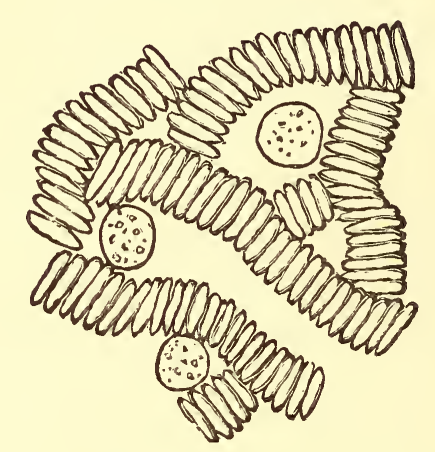

The Amebe peshing their Way among the Red Cells.

one's eyes, to think of the thousands of these odd creatures that go half creeping, half walking through one's veins. You know, people sometimes talk about their "blood crawling," but very few people know how it crawls. But queer and even awful as these little fellows seem to be, they are really among our very best friends, and the more we know about them the better. They belong to the kind of folks that improve upon acquaintance. A great deal has been learned about them during the last few years, and there is a great 
deal more yet to be learned, so you must all try to see what you can find out about them by your own experiments. The red blood-cells are considered of more importance than the white, because they make the blood good and rich; but we cannot study about them just now. If you make the AMCEBA hot, they pull in all their little feet and become perfectly white and still; nothing you can do will ever bring them back to life. The cells I have described are called HUMAN AMœBE, or AMÆBA OF MAN. Those that are found in the blood of other animals are somewhat different; but there is a kind of АMळBA, or crawling

FIG. 65.

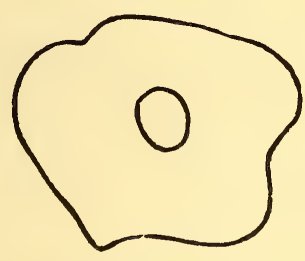

Pond Amciba.
FIG. 66.

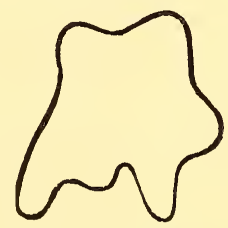

Pond Amcria.

jelly, which grows in stagnant water, that has a greater difference. Take a little of the scum that rises on ponds in hot weather and put it under the microscope, and you will find $A M \Subset B E$ of a much larger size, from $\frac{1}{100}$ to $\frac{1}{1000}$ of an inch in diameter (Fig. 65), moving about by the same kind of queer-looking feet (Fig. 66): But the edge, or border, does not look at all the same. 
First, on the outside, you see a clear, glassy-looking rim; inside of this is a thicker, darker ring, filled with GRANULES, or little grains (Fig. 67). The centre of the cell is quite clear, and contains a VACUOLE, or thin space, like that which you saw in the rorula. The outer border is called the ECTOSARC, which means outer flesh; the inner is the Endosarc, or inner flesh (Fig. 67). In the clear outer flesh, or Eстоsarc, you will find the kernel, or Núcleus, a roundish, solid-looking little body, which does not change its form. If you look attentively, you will see a little, round, clear space

Fig. 67.

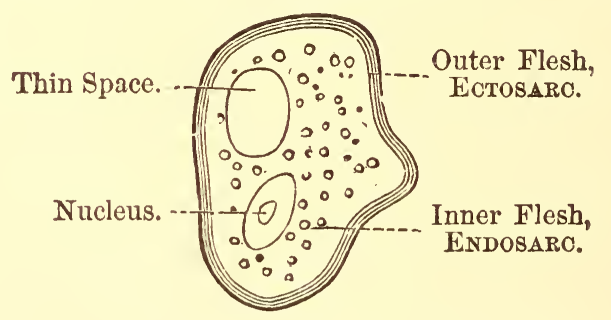

in the outer flesh, or ECTOSARC (Fig. 67), which has a movement something like the beating of the heart. Indeed, by some it is thought to be the simplest form or beginning of a heart. It is called by a long name-the "CONTRACTILE VESTCLE, OR SPACE;" but all AMCBA do not have a heart, nor do they all have a kernel, or nucleus. This "Contractile space," or heart, is very 
important, because it seems to be doing a work of its own. This is the first time we have found one part of a cell doing something different from another part. In the yeast and mould the PRóTоPLAsm-jelly is "maid-ofall-work;" it does every thing-bakes, brews, builds, and "tends baby," too; but the AMcEBA seems to be looking up in the world and trying to pattern after those establishments which support a separate servant for each kind of work. Inside some of these pond AMCEB 世 you will often find green PROTOCOCCUs-cells, DIATOMs, and DESMIDs, and other cells smaller than the

FrG. 68.

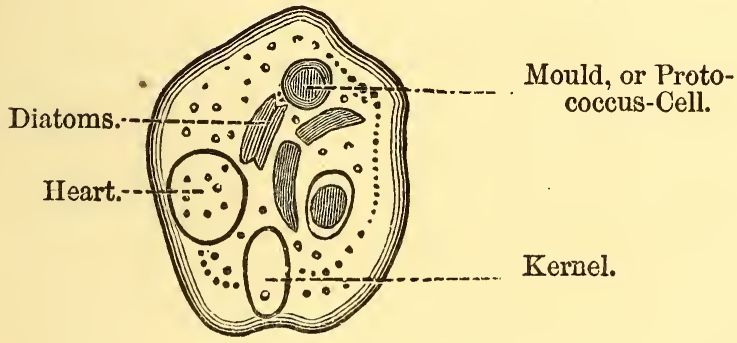

Pond-Amøba digesting its Food.
Fí. 69.

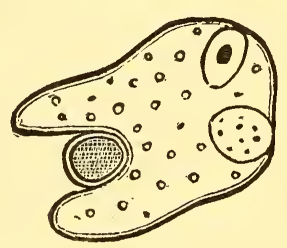

Amoisa eating.

amœba-cell itself (Fig. 68). These it feeds upon, and, if you have patience to look long enough, you will .see how it eats (Fig. 69). It has no particular mouth; the feet seem to taste of whatever comes in their way, and, if they like it, they grasp it and poke it in anywhere through the jelly, or PRotoplasm, which closes all 
around it and at once begins to digest it, and all parts that cannot be used are poked out again. The cells that are swallowed are like so many jars of "Liebig's Extract;" all that the AM the meat, or PRoteIn, and throw out the empty jar, or cell-wall. There is something you must remember about the AMÆBA-it must have its food, or PRoTEIN, ready made. It has no power, like the TORULA or PRoTococcus, to manufacture its own food from the raw material. So this little creature that goes crawling through our blood must be an animal! You recollect all vegetables make pRotein, while all animals eat it up. This little animal gets its full share-it is a perfect little gourmand, taking in every thing that comes

FIG. 70 .

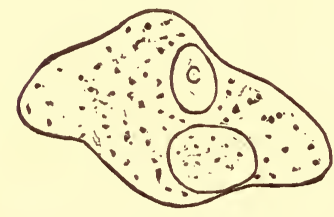

Wild AMgeba.
FIG. 71.

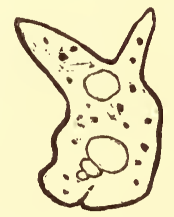

HuMan AMgba.
FIG. 72.

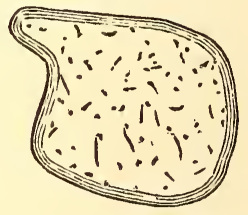

Amceba making a Foot.

in its way. The HUMAN AMÆBE seem to be more fastidious in their tastes and manners, they do not swallow their food whole like the wild AMÆBe; but those of the frog and newt are regular little cannibals, and eat up their "colored brethren" whenever they get the 
chance, though, as I told you before, these "colored folks" are more important than the "white folks." The feet, or PSEUDOPodia, of the savage tribe (Fig. 70) are thicker and shorter than the feet of the civilized kind (Fig. 71). It is very curious to watch how a foot, or PSEUDOPODIUM, is made, especially that of the pondАмщва. First, there is a little swelling or lifting up of the glassy rim, or ECTOSARc (Fig. 72); as this swelling gets larger, some of the inner flesh, or ENDOsaRo, flows into it, carrying the little grains till the swelling becomes quite filled (Fig. 73). Then the walking is. so funny; the feet do not act as the feet of other animals,

FIG. 74 .

FIs. 73.

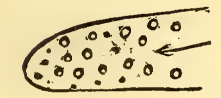

Grains Flowini inro Fоот.
Fi 75.

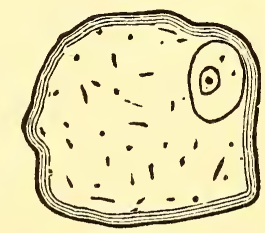

Stained with Magenta.

carrying the body above them; one stumpy foot is put out as far as it can reach (Fig. 74), then the body all runs into the foot; and another foot is stuck out from some other part, and away goes the body into this foot. This is the way it gets on; the feet actually swallowing the body! The toad sometimes swallows its old skin, but the AMœBA is the only animal I know which is 
"taken in" by its feet. How odd it would be if, as you walk along, you should suddenly disappear into your boots! If you crush the AMœBA, you find no trace of a tough sac, as you saw in the tonula or PRoTococcus; you can see the NUCLEUs only, and that but for a little while. If you stain with magenta or iodine, the whole substance becomes colored alike (Fig. $75)$; if there were a sac, it would not be stained. The iodine does not give it a blue color, so there cannot be any starch in the Амळва. The new Амळвж, or bloodcells, are made like the new Pвотососсr, or mould-cells, by Fission. You will first see two NucLei, or kernels, in one of the old cells. If you watch closely, you will see a partition (Fig. 76) going straight through the

FIG. 76.

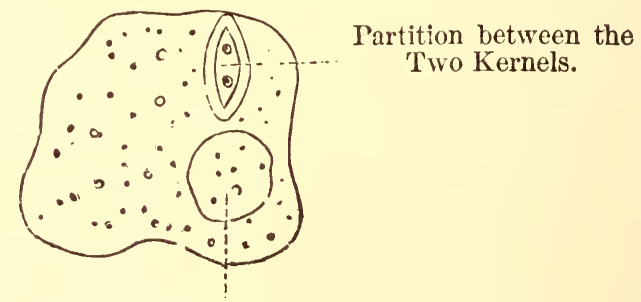

Heart.

body of the old cell between the two kernels-thus are formed two new cells, each within its own kernel, or NUCLEUs-and these follow in the footsteps of their ancestors, making new kernels and new divisions. If 
poor Fatima had known what you know, and had possessed a microscope, she might have employed herself in examining the blood on the key, instead of waiting in fear and trembling for the return of her wicked husband. And perhaps even old Blue-beard himself, - under her teaching, might have become a useful scientific man. 


\section{CHAPTER V.}

THE FRESH-WATER HYDRA.

How the Lasso of the Indian is used by the Inhabitants of the Ponds and the Seas, and how the Boys and Girls may outdo Hercules.

Have you ever heard of the twelve labors of Hercules? You know Hercules was very strong, stronger even than the big giant Jack killed. When he was only eight years old, he squeezed to death two big snakes that came to eat him up. This was fine fun for Master Hercules, but his little brother aroused the whole house with frightful screams. When he became a man everybody was afraid of him, and many were jealous of him. One of his enemies thought to get rid of him by making him do twelve very hard things, such as killing wild beasts, monsters, and serpents. One of the serpents was called a HYDRA; it lived in Lake Lerna, and had fifty heads; as fast as these heads were cut off and smashed up, each grew again into two new 
heads, so the more the snake was killed the faster it grew, and poor Hercules was in danger of being devoured. At last he began to burn the root of each head with a hot iron: this was a success, the head

FIG. $7 \%$.

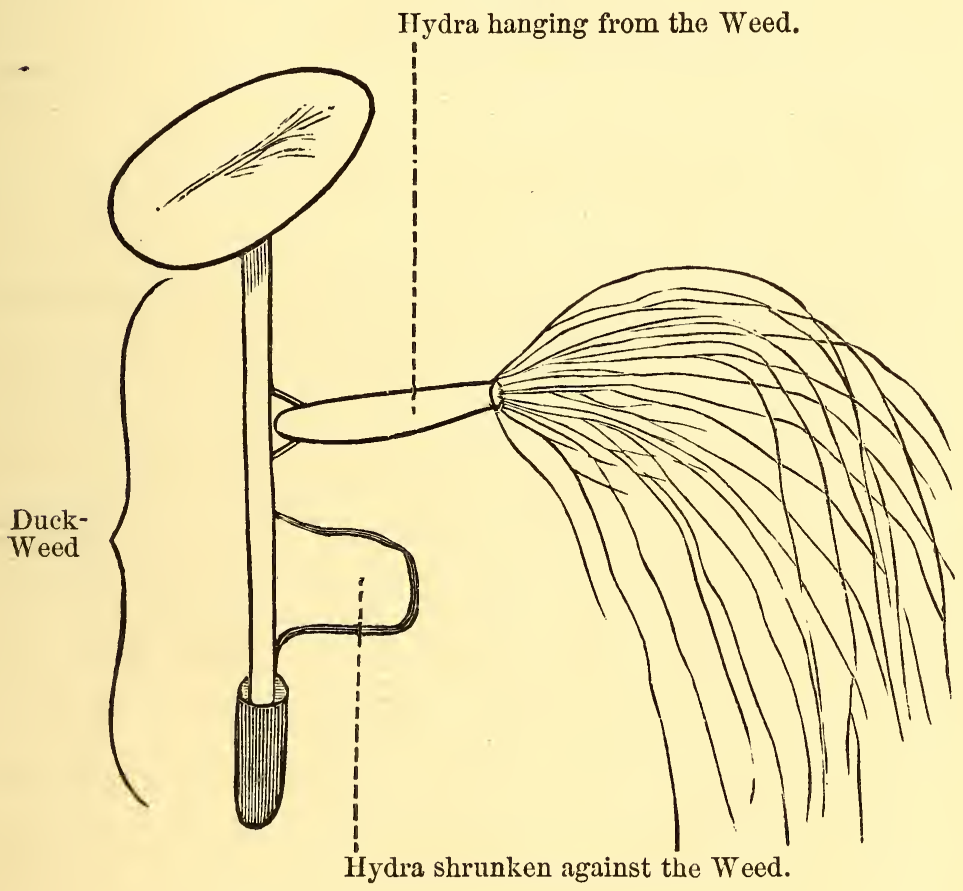

never grew again, and Hercules triumphed over his enemies.

Now I am going tell you about a hydra, but it is not such a monster as Hercules killed, nor need you go away to Greece to find it; you know boys, and girls too, sometimes love to wade in ditches and ponds in the 
warm weather. Some of these days when you are thus wading, if you will take up a piece of the duck-weed you find in the water, you may see a number of slender, green, brown, or orange-colored things, about half an inch long, hanging down from the weed (Fig. 77). If you shake or touch them the least bit they will get sulky, and shrink all up against the stem (Fig. 77), look-

FIG. 78.

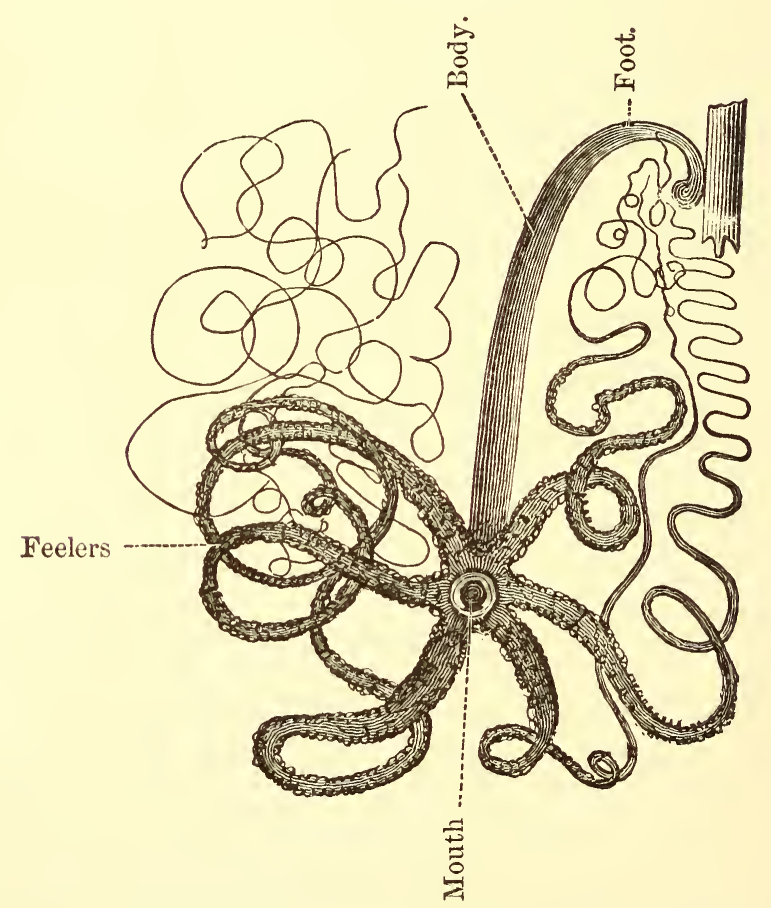

Hidra fishing for Food with its Feelers, or Tentacles.

ing like little pouting lumps of jelly. Place your bits of weed in a glass of water, and put the glass in the 
light, but not in the sun, in a few hours you will find many of these little creatures clinging to the side of the glass toward the window. They hold on to the glass by one end, and all around the other end, which is wider, are a number of long threads called TENTACLEs hanging down gracefully in the water (Fig. 78). At first you might think them whiskers, as they grow out around the mouth; but TENTACLE means a feeler, or holder, and with its TENTACLEs you will see how our little friend feels and holds its food and carries it to its mouth, just as you use your fingers. These little animals are called HYDRE, because, if you cut them up into pieces, each piece will grow again as did the heads of the old Greek monster. If you look at the HYDRA under the microscope, you will find all these parts (Fig. 78). First there is the part by which it holds on; it is round and hollow, something like the bottom of a fly's foot, and it changes its size whenever the body of the HyDRA changes its form. When the HYDRA is stretched out to its full length, the foot is smaller than the body, and, when the HYDRA shrinks back against the weed or glass, the foot is larger than the body. When it is stretched out, the body is round and hollow like a pipe-stem, or more like a very slender funnel, and the large opening surrounded by TENTACLEs, or feelers, is the mouth (Fig. 79). The Hydra's tentacles are not all the same length, 
and some of them are prettily colored, and each one has wavy knobs along its sides (Fig. 79). The bag, or body, of the HYDRA is made of two coats; the outer coat is the ECTODERM, or outer skin, the other is the ENDODERM, or inner skin. The cells of the outer skin, in the green

FIG. 79.

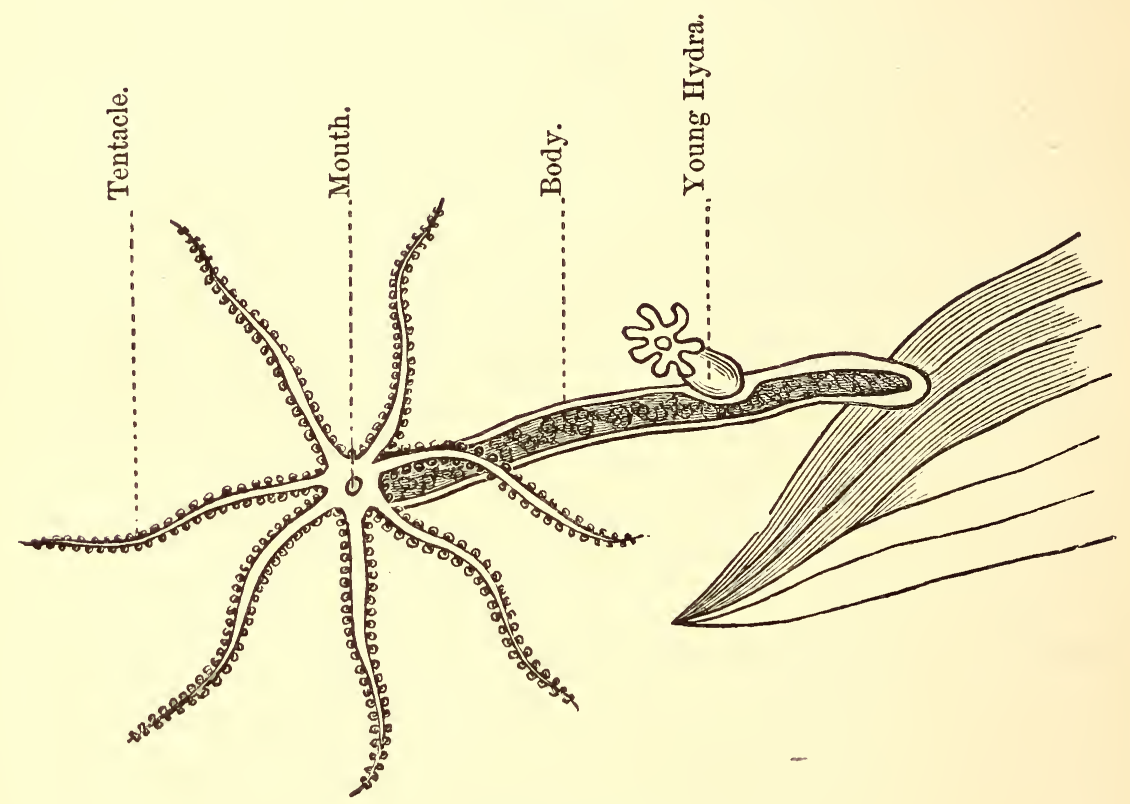

Green Hydra.

HYDRA, contain color-grains, or CHLOROPHYL, which gives the green color. It is curious to see that the HyDRA makes its fingers (Fig. 80) as the АмळвА makes its feet, by pushing out its two coats, the ECTODERM, or outer skin, then the ENDODERM, or inner skin; but the HY- 
DRA never allows its fingers to swallow it, as the AMGBA is swallowed by its feet. When it is disturbed or frightened it seems to swallow its fingers, or puts them all into its mouth like a sulky child. It is a good deal

FIG. 80 .

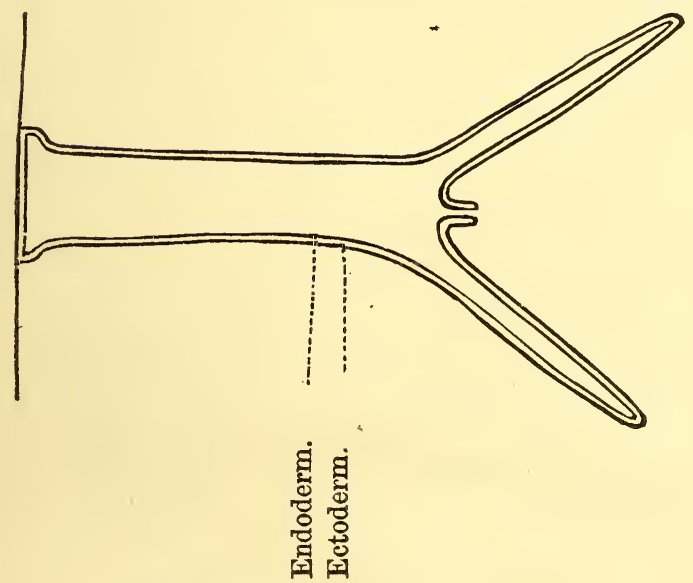

Fig. 81.

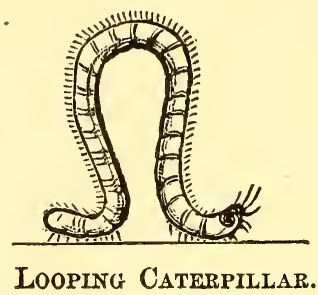

Hydra PUShing OUt its Fingers.

higher up in the world than the blood-cell, or АMсввA, for you remember the АMळBA had to eat with its feet. Then, too, the HYDRA has a more aristocratic walk than the Aмсва. You can see it plant its foot firmly against the glass, then proudly bow its back and draw the rest of its body up to the foot in the form of a loop, like the "looping caterpillar" (Fig. 81). To be sure, it goes backward, but it is a great improvement on the crawling and creeping of the AMEBA; besides, it is a very good swimmer. You may often see it lift up its foot 
and dash into the water in search of its food. It is one of the funniest things in the world to see the HYDRA catch its prey. I remember, in my old geography, a picture of Indians catching wild-horses with lassoes. The lasso is a long rope with a loop at the end, which the Indian skillfully throws over the horse's head. So the HYDRA throws out its long, rope-like fingers, and catches little animals which are swimming near it. Sometimes it gets hold of things which are so strong,

Fig. 82.

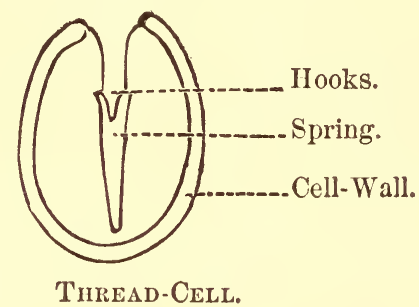

FIG. 83.

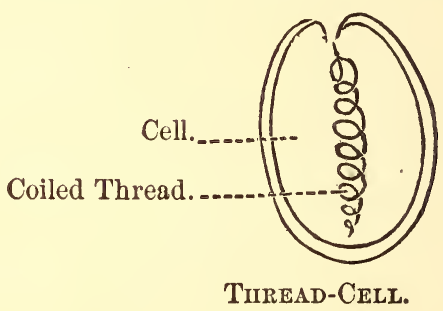

they might tear the lassoes and get away again. But the Hydra has another weapon at hand. Some of the cells of the outer skin are oval, or egg-shaped, and if you look through their walls you will see what appears to be a long coiled thread with two hooks at its base, lying" snugly within each of the cells (Figs. 82, 83). These oval cells are called "thread-cells," and the нYDRA has many thousand of them in its TENTACLES, or fingers. This thread, or spring, darts out of the cell. whenever the HYDRA wants it, and sticks itself into the 
body of the prey like a sharp harpoon (Figs. 84, 85). If you examine the spring closely, you will find that it is only part of the cell, poked in like the finger of a glove

FIG. 84.

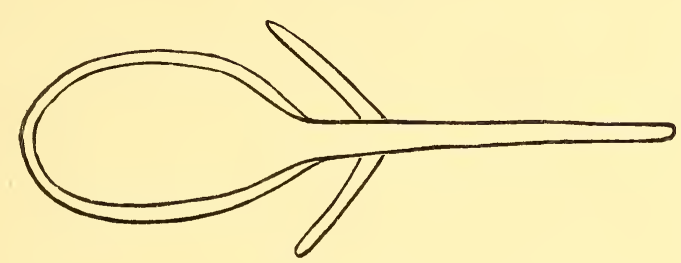

Thread-Cell, with its Thread uncoilled.

turned inward, and when the TENTACLES, or feelers, seize any thing, these glove-fingers all turn out again. Some of them are supposed to contain a poisonous juice,

FIG. 85.

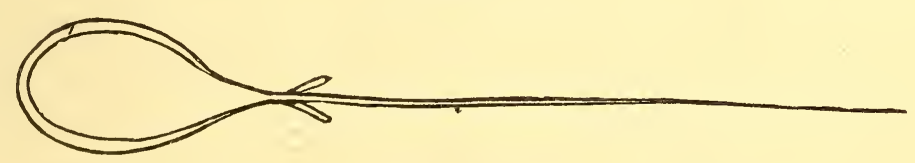

Thread-Cell, with the Spring turned out like a Harpoon.

which stuns or kills their prey in an instant. There is an animal in the sea, the Portuguese Man-of-war, which is really a dangerous creature, it has so many of these sharp harpoons, which it throws at you if you touch it. When the prey is benumbed or dead, the TENTACLES carry it to the mouth, and it passes down into the long tube, or body, of the HYDRA, where it is digested; there is no separate stomach, only one cavity, which runs all 
through the body and ends at the mouth. Along the outside of the body you will often see little buds, which grow and give off other buds, so that the old HYDRA looks like a regular branching tree (Fig. 86). These

FIG. 86.

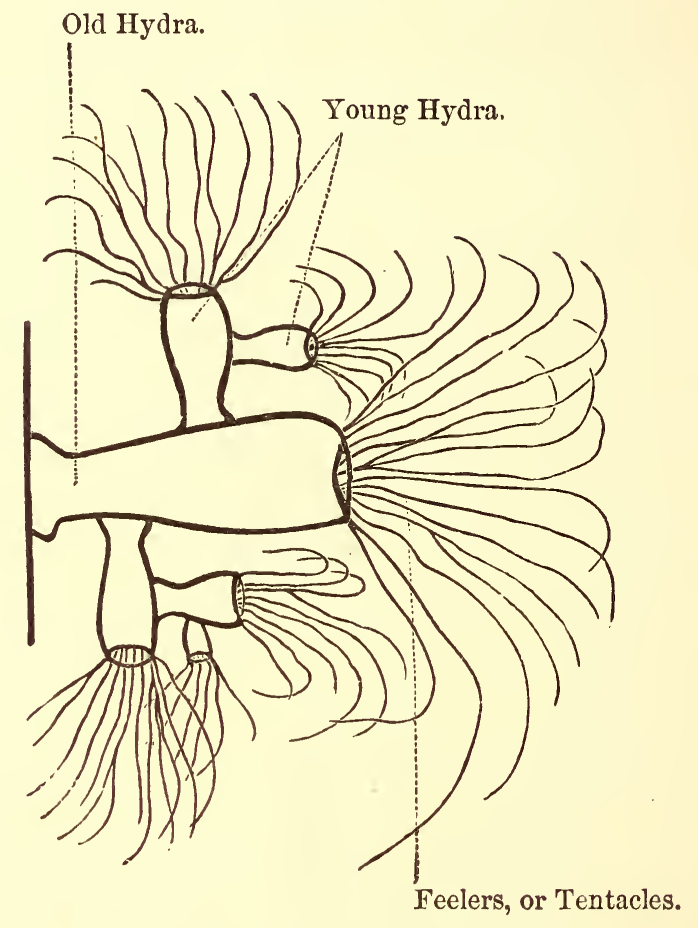

Old Hydra and Young Ones.

buds, no doubt, make you think of something you have seen before, the baby-тоRule. Yes, these are the вaвYHYDRæ. Soon their long fingers, or TENTACLES, begin to grow, then they loose themselves from the old мотнER-IIYDRA and begin to fish for themselves. There are 
other ways in which the BABY-HYDRE are born, but you can study more about them when you become scientific men and women. If you find out all about the HYDRA, you will have done a harder and more useful work than that which Hercules did, when he killed the HYDRA with fifty heads that lived in Lake Lerna. 


\section{CHAPTER VI。}

\section{THE FRESH-WATER MUSSEL.}

How the Boys and Girls broke open the Mussel's House, and what they found in his Two Rooms.

One day, when I was playing "keep-house" with my brothers, we found we had no dishes, so we put our heads together to know what we should do. Finally, we agreed to go to a creek or brook that ran through the woods a long way off, and pick up some of the mussel or clam shells that lay upon the bank. We thought our ripe strawberries would look "so sweet": against the white, shining shells. They are commonly called clam-shells, though the clam is a little different. We picked up a great many, washed them clean in the clear, running water, and put them in our baskets to carry home. Some of them were fastened together by such a nice little hinge, others were broken apart; and we wondered what they were, how they came there, and if God made them just on purpose for 
little dishes. By-and-by I found two of them joined together and buried in the mud, with just a little of the narrow end sticking up (Fig. 87). I pulled them

FIG. 87.

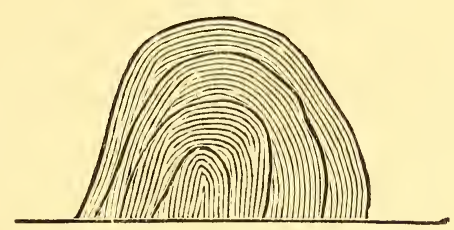

"Happr as a Clam."

out, washed off the mud, and tried in vain to open them. The boys had to try a long time before they could pry them open, and then we saw something inside that looked like a lump of slimy flesh; it actually moved, and, as we thought, opened its mouth to bite u's. We were all frightened, and ran away as fast as possible to tell our mother. She laughed, and told us it was a harmless little creature; that the shell was its house, which it built for itself and carried about wherever it went. After that we used to find a great many of them whenever we went to the brook; but I always felt afraid they might bite, so I kept at a safe distance. It was only the other day that I learned what wonderful little animals these are that live in the mussel-shells, which, I used to think, were made for my dishes. I know you are curious to learn about them. At first you can see only the outside of the shell, or house; but, 
I think I had better take you inside and give you a look at the little fellow himself before I describe his abode. He has not sent us an "at home," and the door is closed and barred; so we must be house-breakers for once, and go in by force without an invitation. The MUSSEL fastens his doors together by four little straps, and we must cut two of these before we can get in. If you will hold the small end of the shell toward you and the linge upward (Figs. 88, 89), I will name the differ-

FIG. 88.

Upper or DoRsal BORDER.

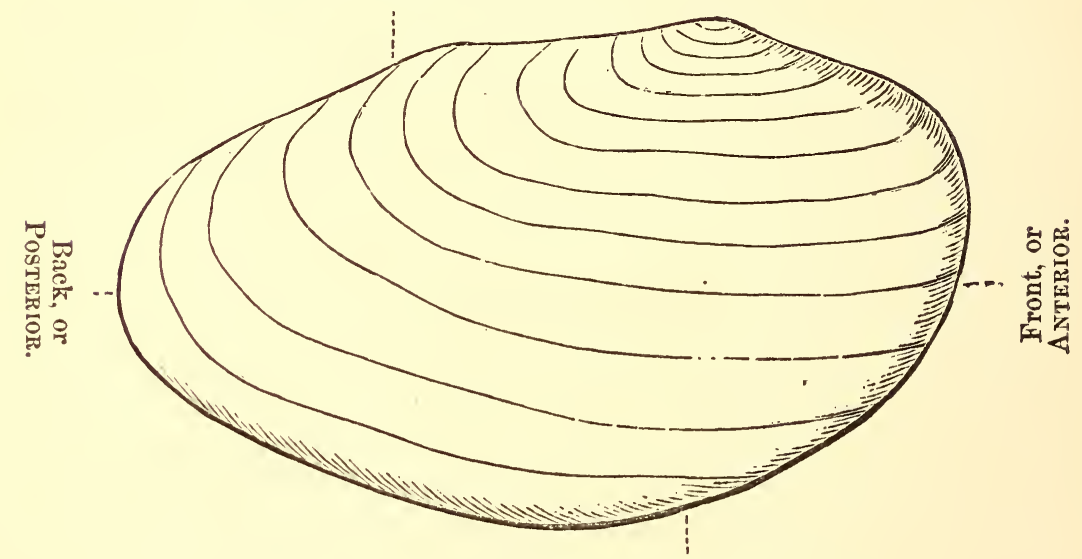

Lower or Ventral Border.

ent directions, and then you can better understand where the straps are fastened, and how the Mussel lies in the shell. The small end toward you is called the back, or POSTERIOR end; the large end in front of you is called the front, or ANTERIOR end. The upper-hinged 
edge, which is nearly straight, is called the upper, or DORSAL BORDER; and the lower rounded edge is the FIG 89.

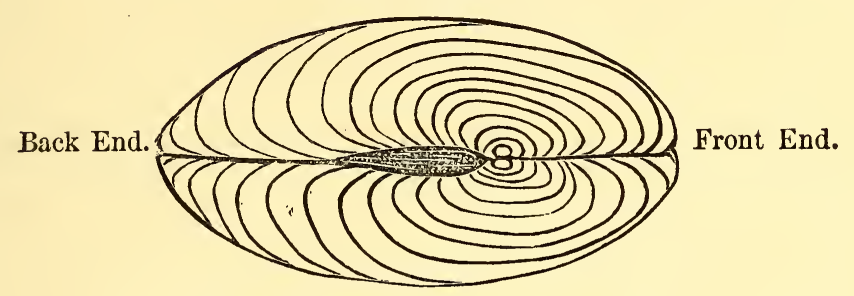

UpPer EdGe of Mussel-Shell.

lower, or Ventral BORDER. Then there are the two sides-one on your right hand, and the other on your

Fig. 90.

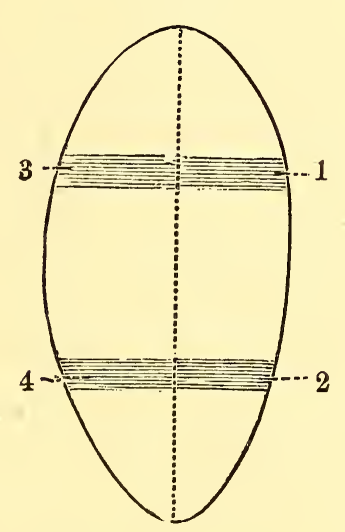

The Four Straps.

left; therefore one is named the right side, and the other the left. So, when you pick up the half of a Mussel-shell, you can always tell to which side it be- 
longs, if you hold the small end toward you, and the hinge upward (Fig. 89). These four straps are fastened quite near the ends, close to the upper, or dorsal border - two on the right side and two on the left (Fig. 90). They are made of an elastic substance called Musche, that stretches or lengthens when the animal wants to open its shell, and contracts, or shortens, when the

FIG. 91.

Mark made by Edge of Mantle-

Left IIalf of Shell. the Palial Line.
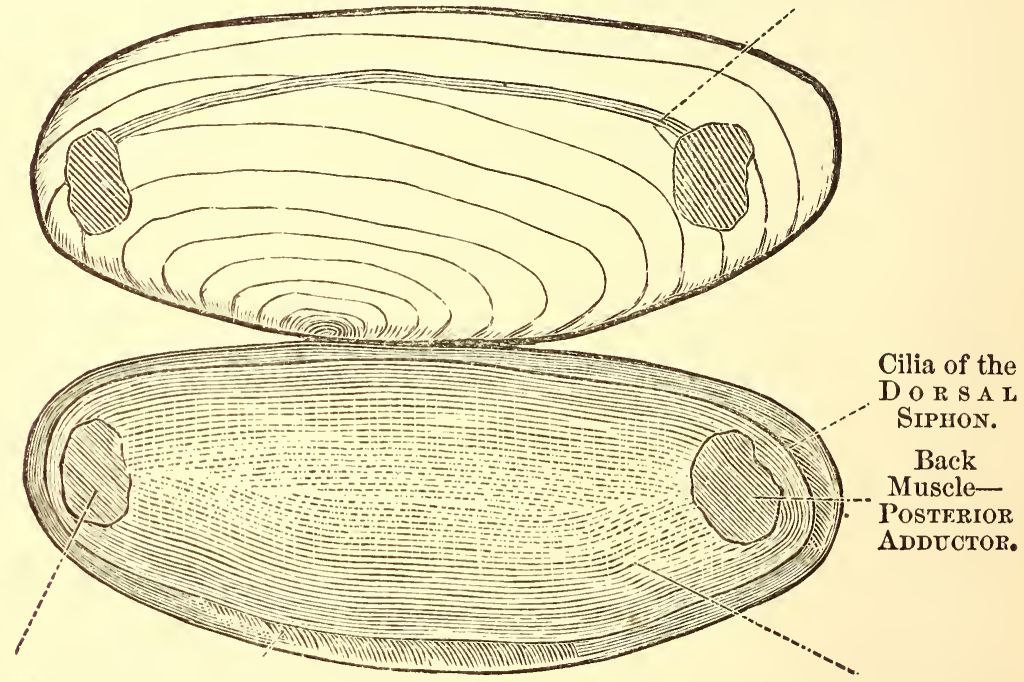

Front Muscle- Lower Ventral Opening Anterior AD- and its Cilia, or Lashes. Mantle, before it is lifted up.

DUCTOR.

shell closes. Now, we are ready to break into the house, since we have found where the fastenings are. If you lay the mussen down on his right side, the large 
end will point toward you and the small end away from you. Then, if you slip the edge of a thin-bladed knife in between the shells at the small end (keeping the knife close to the shell) and drawing it carefully toward you, you will cut the two straps, or muscles, of the left side, and then you can lift up the left half of the shell, and you can also see where the straps have been fastened to the shell (Fig. 91). The muscle on the large or front end is called the ANTERIOR ADDUCTOR, and the one near the small back end the POSTERIOR ADDUCTOR. They are called ADDUCTORs, because they bring to and keep together the sides of the shell; the word adductor comes from the Latin-ad, to; and duco, I lead. So the ADDUCTor muscless lead, or bring to, the MUssel's shells. After you lift the shell, you will see a mass of slimy-looking substance; but this is not all. If you take hold of the yellowish edge toward your left hand, you will find that it lifts up as you lifted up the shell (Fig. 91). This edge seems to be the border, or trimming, of our little friend's cloak, which is shaped quite like the shell; in fact, it lines the shell with its two halves. These halves are joined together on the upper or dorsal edge, and they are also united for a little distance on the ventral, or lower edge-at the back, or Posterior end, so that you might call these two linings of the shell the Musser's blankets in which he lies; but 
they are called the "MANTLE" (Fig. 91), and they make the Mussec look as though he were dressed in a long oil-silk water-proof with a yellow border. This mantle is made of a thin skin which is almost transparent, looking much like oil-silk, only it is not quite so shiny. In the border are a number of tiny, elastic MUsCLEs, which hold the MANTLE fixed to the shell. In olden times people used to line the walls of their rooms with silken and velvet fabrics, called tapestry-some of it was all embroidered with beautiful pictures; one kind, called the Gobelin tapestry, is still made in Paris; when you go there, you can see them making it. It would not be a bad idea to call this MANTEL the MUSSEITAPESTRY, because it lines the walls of the MUSSEL's house. A brother of the Mussel, called the scallop, wears his pretty eyes in the border of his MANTLE. How funny it would be if your eyes were in the hem of your water-proofs and overcoats! The MANTLE has two openings, and around these openings the edge of the MANTLE is fringed by strong hair-like processes called cilis (Fig. 91), like the eyelash oars of the green water-rowers, but shorter and stronger. The opening on the DoRsal, or upper side, is small and oval, and it is called the DORSAL SIPHON-siphon means a tube, or pipe, and after a while you will see why this name is given to the opening. The other opening is larger, and 
reaches all around the front of the MANTLE to the place where the two halves are joined behind. This opening is called the ventral siphon (Fig. 91). It is the edge of this lower opening that you lift up to enter one of the chambers of the Mussel. He has but two rooms; and this one that you enter by the large lower opening, or ventral siphon, is the larger of the two. - This is the room in which the Musser keeps his foot, which is the biggest part of him (Fig. 92). He must belong to the yellow-skinned race, for his foot is very yellow, and such an odd shape! more like a ploughshare than a foot, though the foot of the COCKLE, another brother of the musser, looks like the foot of a fat baby. The toe of the foot is turned toward the ANTERIOR or front end of the shell (Fig. 92), and it bends downward a little toward the lower ventral border, the shape of your foot when you pull your heel back against your ankle. The foot contains elastic Muscle in its walls, and, when our little friend gets tired of staying in one place, and wants a change of air or food, he uses these muscles to push his foot through his mantle by the ventraL sIPHON (Fig. 91), the large lower opening, and then out between the edges of the shell. Then he curves his foot and hooks it on to something, while he pulls the rest of his establishment after him; but, for the most part, the mussel is not a traveler. He bores or 
digs a hole with his foot, which he uses as a drill, or spade, and buries himself in the soft, warm mud, and enjoys himself immensely. I suppose this is what is meant by being "as happy as a clam." The clam is one of the mussel's cousins. He has an ingenious way

Fig. 92.

Left Half of Shell.

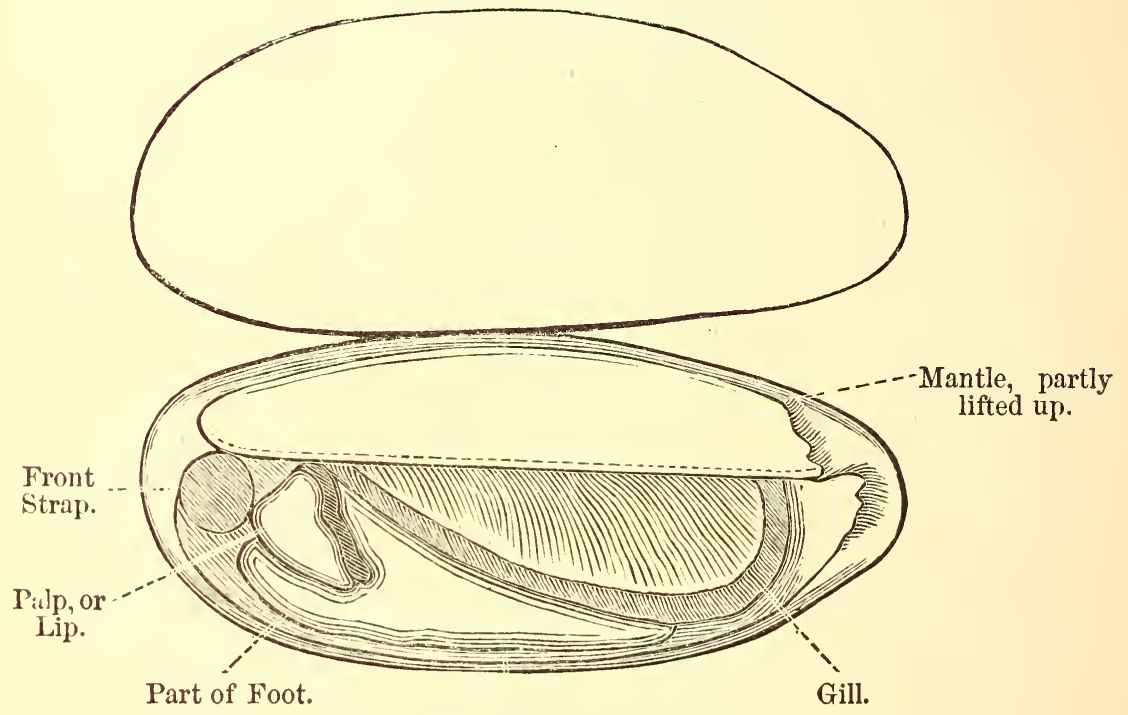

of making the hole in the mud large enough to hoid his shell. The foot is much smaller than the end of the shell; so he increases the size by filling his foot with water while he is digging. But the oddest thing of all about the foot is, that the ears lie in it. We thought it very odd to see the little blood-animal-the AMÆBA-eat with its foot. Imagine you stretching out 
your toes to listen to what I am saying! The Mussec is not a "long-eared animal;" indeed, its ears are so very small, that you can hardly see them with the naked eye. If you get a young Mussel and look closely, you will find two little bags, called EAR-SACs, one in each side of the foot (Fig. 103). They are full of fluid, and

Fig. 93.

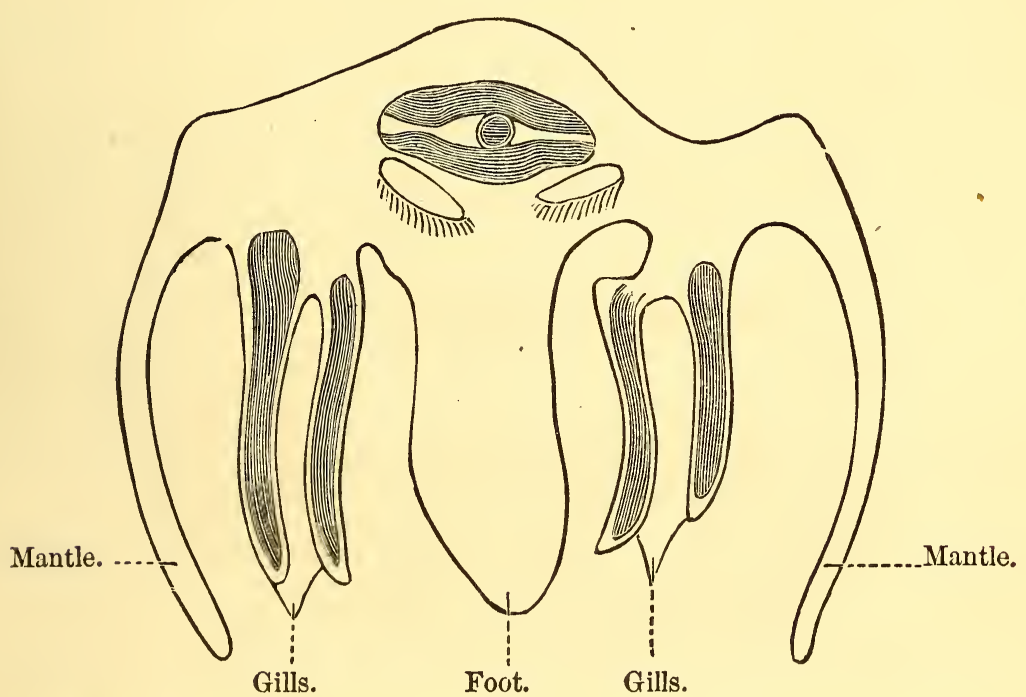

Mussel cut crosswise, showing the Postition of Foot, Gills, and Mantle.

in the fluid are some very little stones, called отоцттнs, which keep up a trembling motion. These little stones make the sounds stronger, just as the pebbles on the beach increase the sound of the waves. Though these ears are so small, they are very sharp; for, if you make the least noise when the foot is out of the shell, the 
MUSSEL will pull it in instantly and shut its doors. Remember we are still in the big chamber, and in the same room, hanging down on each side of the foot, are two striped-looking bodies, called GILLs (Fig. 93), one lying a little over the other. The two outer ones are fastened above to the MantLe (Figs. 93, 94), while the two inner ones are fastened at their top to the foot

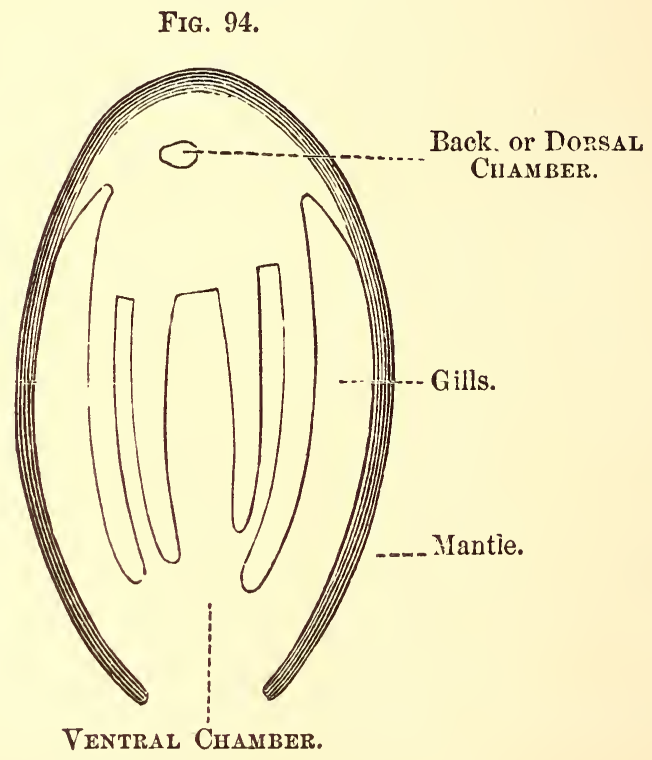

(Figs. 93, 94), and are joined together behind, making a partition between the back-room and the large, family sitting-room in front.

Each room, or chamber, has its doors. The door which leads from the front-room into the back-room lies in front of the hindmost muscle, the POSTERIor AD- 
DUCTOR, and the door which leads out of the back-room is the upper tube, or DORSAL sIPHON. This little backroom, or DORSAL CHAMBER, which lies behind the inner GILLS, is also called the CLOACAL CHAMBER, because it is the place where the intestinal tube empties. Cloaca means a sewer, or drain. There is a very old one, which empties itself into the Tiber, at Rome, called the Cloaca Maxima, for it is so large. When the water is low; you can see this great opening in the bank, and it looks like the mouth of a cave. Now, what is the use of the gills? Perhaps, if we try to see

FIG, 85.

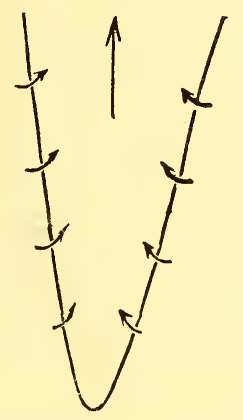

V-silaped Gill-Pocket.-The Areow-Hends point the Direction of Currents.

how they are made, we can find out what they do and what they are made for. Each GILL is a little pocket, shaped like the letter $\mathrm{V}$ (Fig. 95). If you look at the GILLs, you will see a number of strips, or lines, running up and down, and if you put a very small piece under 5 
the microscope, you will find other stripes, or bars, going crosswise (Fig. 96). These two sets of lines make a lattice-work, which forms the sides of the pocket, and over this lattice-like framework is stretched a thin skin, which is all filled with little blood-vessels. The openings of the lattice-work are all surrounded by very strong moving ciLIA, or lashes (Fig. 96), like those we

FIG. 96.

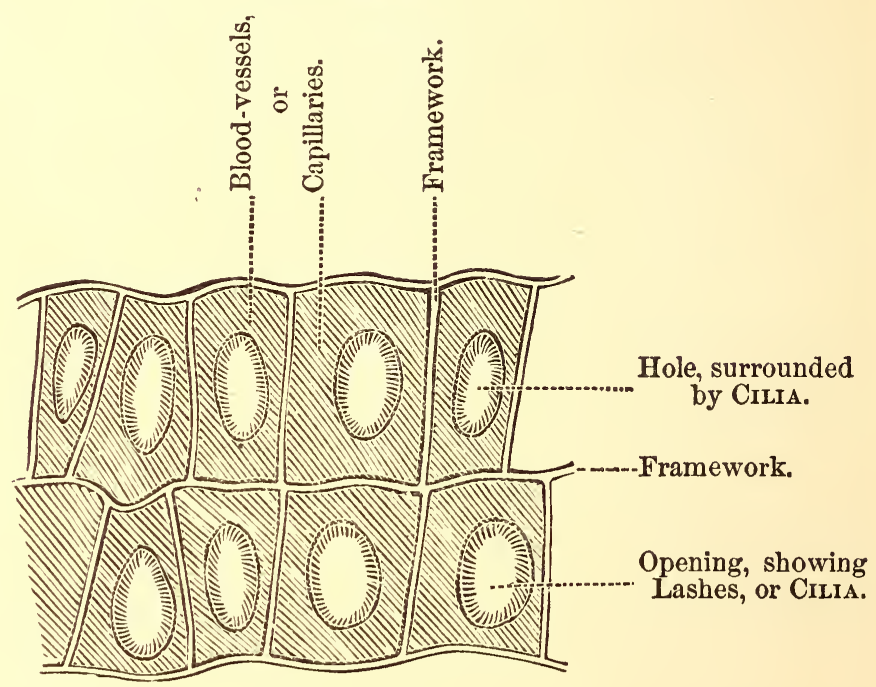

a Piece of the Gill-Pocket, showing Blood-Vessels, Framework, and Cilia.

saw around the two openings of the MANTLE-the DoRsal and ventral siphons. The cilia, or lashes, are always moving, and as they work they lash the water through the openings of the lattice-work into the pockets of the GiLLs (Fig. 95), and out again by the door 
which leads into the back-room, or DORSAL CHAMBER. Now, what is the use of the water, and why should it be kept in constant motion? The little blood-vessels in the skin of the pockets are full of bad blood, which comes to the GILLs to be made pure; that is, to get oxyGEN, just as your blood must go to your lungs to get oxyGen. Your lungs get oxyGen from the air which you breathe in, and they give out the bad air, or CARBONIC ACID, which comes out with your breath. The blood-vessels of the GILLs get their OXYGEN from the air in the water. They take it up as the water rushes over them, and give up the CARBonIC ACID which they do not need. So now you see why the lashes keep moving; the blood-vessels in the GILLS must have fresh water continually, and the CILIA are like so many million little paddles, or fans, of a windmill, that make a strong current inward through the gills, from the vENTRAL or front room, to the DORSAL or back room. The current of water rushes into the house of the mussel, by the large ventral siphon, or the lower opening. You know that this sIPHoN is fringed by strong hairs, or CILIA (Fig. 91), so they bring in the water from the outside, and the hairs on the GILLs carry it on. The GILLS are the mussel's lungs, but he never has consumption or lung-disease, because he always supplies himself with plenty of fresh water. We have seen how the water 
gets into the house, but how does it get out? It cannot go back by the large, lower opening, or VENTRAL sIPHoN, because there is such a strong current of fresh water coming in; if it did start to go that way, the lashes, or cILIA, would throw it back, because they are all sweeping the water inward. There must be some place to get it out, else our poor Mussel would soon die. The water from the GILLs passes through the door which opens from the front or ventral CHAMBer, into the DORSAL or upper back-chamber, and then out of the house by the DORSAL SIPHON-the small upper tube. This back sIPHon, or tube, is also fringed with strong hairs (Fig. 91), and these sweep the current outward. These cIlis, or lashes, around the openings, are known as the mussel's beard. But all the water which enters the house does not go to the GILLs, the rest of it enters the mouth. Now, where is the mouth? It is quite a puzzle to find it, for the Mussel has no head, and hence has been called acepHaLous, which means headless. If you go into the big room, or ventral CHAMBER, and look about carefully, you will find, just in front of the GILLS, a small V-shaped flap (Figs. 92-103), which is joined to another one of the same shape on the other side, and between these two flaps you will discover a wide aperture, and this is the mouth (Fig. 103). The two flaps are called labial Palps, or lip-feelers. The Mussel 
has no tentacles, or threads, to lasso its food like the IIYDRA; but its mouth is edged with CILIA, which make the water move inward. This water is full of live little animals, which make delicious "eatings" for a hungry Mussel. If you pass a bristle through the mouth, it will go upward toward the dorsal edge of the mussel, through a tube which opens into a squarish bag (Fig. 97). The tube is called the ๔sophaGus, or meat-pipe; it is sometimes called the gullet (Fig. 97). You have

Fig. 97.

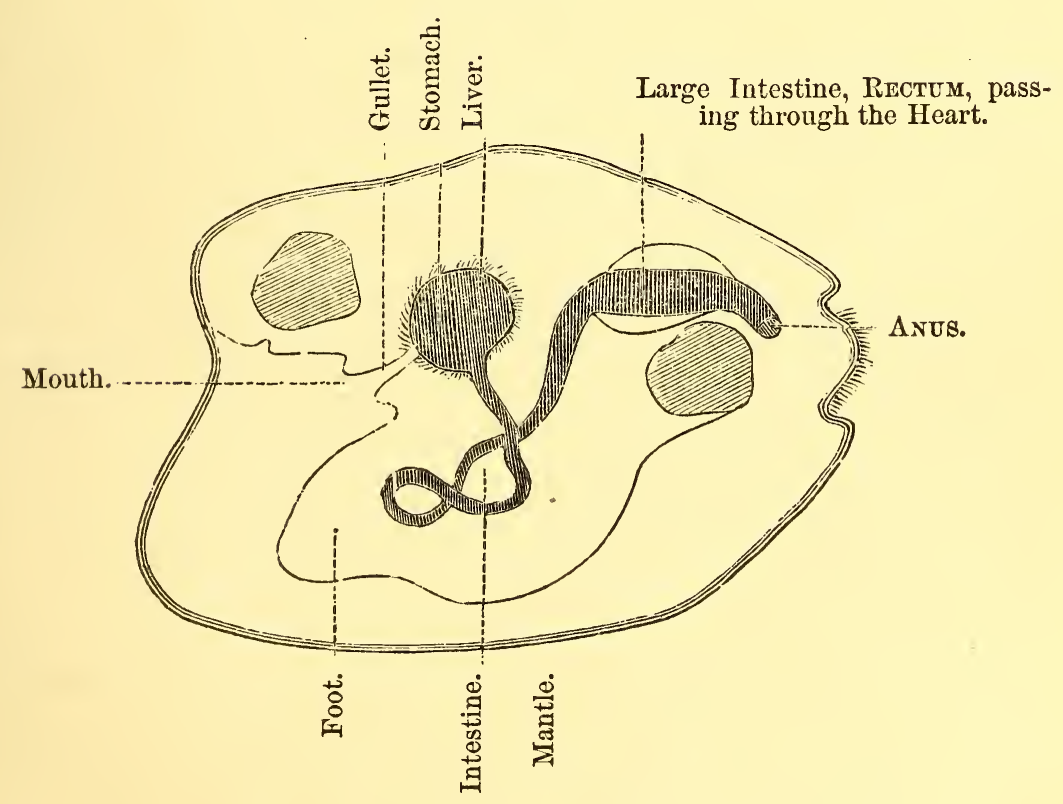

one just behind your windpipe, and it leads from your mouth to your stomach; but the mussel does not need 
a windpipe, because it does not breathe air. The squarish bag is the stomach, and at the back part of this you can see the opening into a long, narrow tube, which is the intestine. The intestine then leaves the stomach, and runs down into the foot (Fig. 97), where it seems to get bewildered, and after two turns passes out again, and goes up to the DORSAL edge of the body, runs right through the heart straight back to the CLOACAL CHAMBER, where it ends by a small opening called the anus (Fig. 97). The stomach and intestine pick out all the best part of the food that is in the water, and the waste part which the Mussel cannot use passes out of the ANUS into the back-room, or CLOACAL CHAMBER, and is carried off by the current of water that is rushing out by the dorsal siphon. Now, we have followed the water which contains the air and food, into the MusseL and out again; one part of it goes through the large front-door, or ventral siphon, into the large frontroom, or VENTRAL CHAMAER, over the GILLs through the middle door, which leads into the little back-room, or CLOACAL CHAMBER, while the rest of the water goes through the mouth, INTEstine, and ANus, into the same little room, or CLOACAL CHAMBER, and then both parts go out again through the little back-door, or DORSAL SIPHoN. Its journey is a long and useful one, for it gives life to the mussel as it goes. If you wish to see it for 
yourself, put a fresh unopened MusseL with the small end upward into a tumbler of water containing a little indigo, and the blue grains will show you the direction of the current. You can see the grains go in at the large and out at the small end (Fig. 98). I have spoken

Frg. 98.

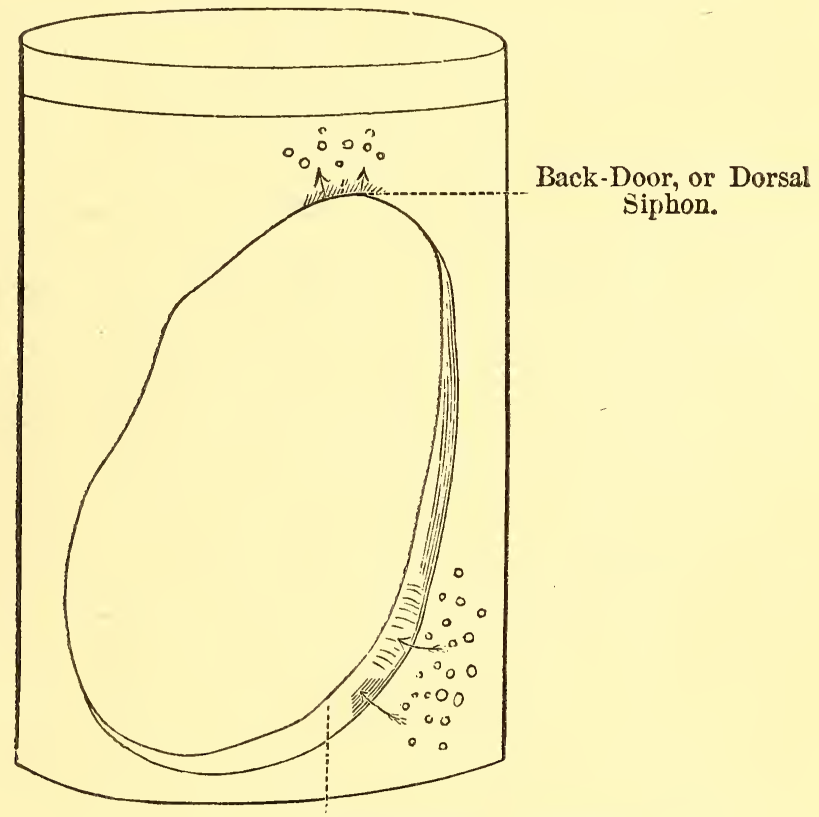

Front-Door, or Ventral Siphon.

Cram, or Mussel, in a Vessel of Indigo Water.-The Arrows point the Direction of the Current, as seen by the Grains of Indigo.

of the heart, through which the Intestine passes. In order to see the heart well, you must get a fresh MusseL and lift him entirely out of his shell; but, before you can do this, you must cut all the straps, then, if you 
still hold the animal with the straight DORSAL BORDER upward, you can see where the two halves of the MaNTLE are joined together. Near the front you will notice a thin, transparent part of the mantle, and if you look through this spot you can see something beating. This

Fig. 99.

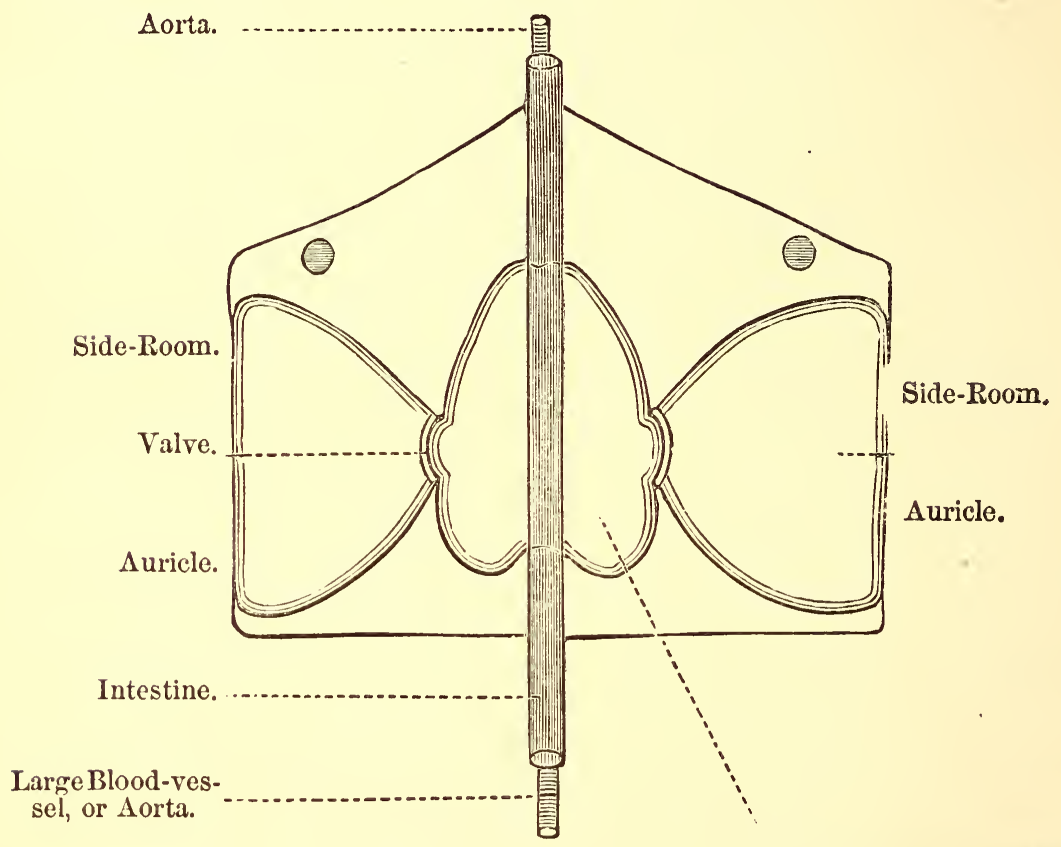

Middle-Room, or Ventricle.

Mussel's Heart.

thin place forms the upper part of a sac-a cavity filled with fluid, and in this sac, surrounded by this fluid, lies the heart. This accounts for the beating. The sac, or bag, is called the PERICARDIUM, because it surrounds the 
heart. Peri means around, and kardia the heart. The MUUSSEL's heart has three rooms, one at each side and one in the middle (Fig. 99). The side-rooms are called AURICLES, because in your heart they are ear-shaped, but in the MUSSEL they are more like wings fastened to the central chamber. The central chamber is the veNTRICLE, but your heart has two VENTRICLES, which with the two AURICles make four rooms. If you look carefully while the heart is working, you can see that the ventricle, or middle-room, draws itself together and then swells out again ; next, the two side-rooms, or AURICLEs, draw themselves together and swell out, and, while they are swelling out, the ventricle begins to draw itself together again. This regular motion of the little rooms, the AURICLES and vENTRICles, is called the beating of the heart. If you count the beats, you find they are about fifteen in a minute, less than onequarter as fast as yours. Why does the heart beat? In order to receive the blood and send it through the body, and the flowing of the blood through the body is called the circulation of the blood. When the middle-room, or VENTRICLE, closes or draws itself together, it sends the blood into little tubes called arteries. Artery means air-container, or air-tube; for long ago, when doctors opened dead bodies, they found these tubes empty, and they supposed wrongly that they were filled 
with air. It was afterward found out that they carried the blood from the heart. These ARTERIEs carry the blood over all the body, and they get smaller and small-

Fig, 100.

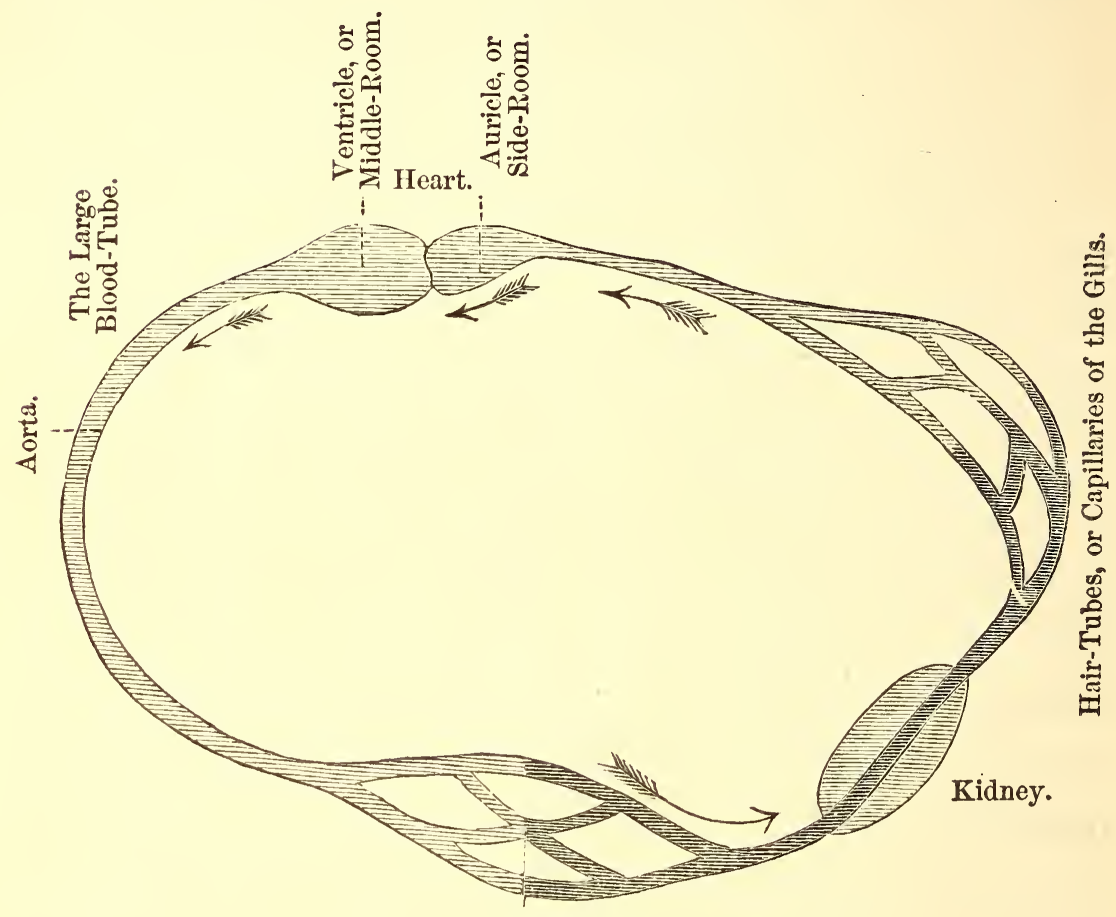

Hair.Tubes, or Capillaries.

The Circle which the Blood makes going from and to the Heart.-The Light Lines stand for the Pure Blood, and the Dark for the Impure.

er until they end in very tiny vessels called CAPILLARIES, because they are so fine-even finer than hairs. You may not know it, but every hair on your head is a hollow tube. As the blood passes through these hair-like 
tubes, or capillaries, it gives up to the body the pure oXYGEN and other good matters it contains, and receives the poisonous CARBONIC ACID and waste part, and hence when it leaves the capillaries it is bad (Fig. 100), or what is called venous BLOoD. When the blood leaves the fine hair-tubes, or CAPILLARIEs, it enters vessels called veINs, and they carry the blood to the kidney, where some of the bad matters are strained off. It continues its journey, and now enters the GILLs, and is spread out in a net-work of fine CAPILLARIES over the lattice-work of the GILL-Pockets (Fig. 96). There the blood gives off its CARBONIC ACID and receives OXYGEN. Now it is pure again, and is carried by vessels and poured into the two side-rooms," or AURICLES, of the heart (Fig. 100). The AURICLES close or draw themselves together, and force the blood through little folds, or valves, into the middle-room, or ventricle. The VALVES do not allow the blood to return to the AURICLES. The VENTRICLE draws itself together and sends the blood into the tubes called ARTERIEs, to continue the same course, and, as the blood goes in this circle through the body, its course is called the circulation of the blood. But why do we not see the blood in these rooms passing from the AURICLEs into the VENTRICLE, for the walls are transparent? If the blood were red like yours, you could see it moving along, but it has none of the red 
cells which you saw in yours under the microscope. The blood of the Musser is made of water and colorless cells, which move about quite like the HUMAN AMÆBE. Below the heart-sac, or PERICARDIUm, lie the kidneys: they are also called the organs of Bojanus, from the name of their discoverer. They have two chambers, an upper and a lower (Fig. 101). The upper one is clear

FIG. 101.

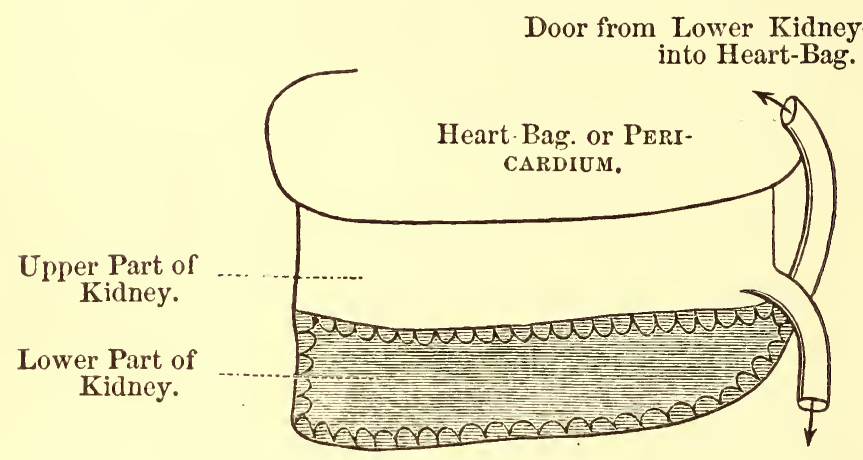

Door from Upper Kidney into FrontRoom, or Ventral Chamber.

and transparent, and has a door which opens into the mussel's big room, or ventral chamber (Fig. 101). The lower chamber of the kidney is of a dark, chocolate color, and it has a door which opens into the heartbag, or PERICARDIUM (Fig. 101). It is in the dark, under part, where the blood which runs through the kidney is made pure (Fig. 102). Around the stomach lies a dark-brown-looking mass, and this is the liver. It makes or manufactures BILE, and pours it into the stom- 
ach. I wonder if the poor ANODON (another name for the Musses, meaning toothless) ever gets bilious, and if his doctor makes him take "liver-pills?" He may not

FIG. 102.

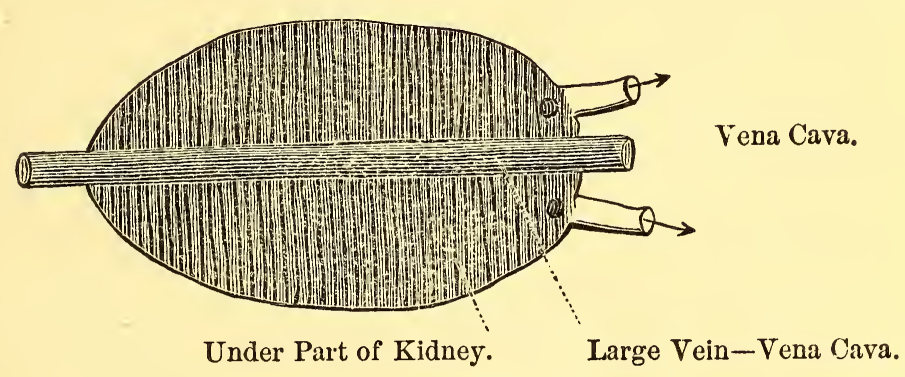

suffer from bile, but I should not be surprised if he had nervous attacks like neuralgia, he has so many nerves. At each side of his mouth, and at the base of the palps, is a little mass of yellow nerve-matter about the size of a pin-head (Fig. 103). Each mass is called a GANGLION, which means a bunch, or swelling. The two bunches - GANGLIL - are united by a white nerve-cord, which forms a loop above the gullet, or שsophaGus (Fig. 103). These "bumps" are our friend's. brains, though he has no head to put them in. No doubt you all think it better to have brains without a head, than a head without brains. Another cord leads from each head-bump, or ganglion, down to the foot, where it joins another little mass of nerve-matter, one on each side of the front of the foot (Fig. 103). These are the PEDAL or foot GAN- 
GLIA, and they are larger than those of the head; eggshaped and of a bright orange-color, so it is quite easy to discover them. Indeed, you might imagine the mussEL wore tight boots, and that these were his "corns." Each one gives off a nerve to the ear-bag, which you

Fig. 103.

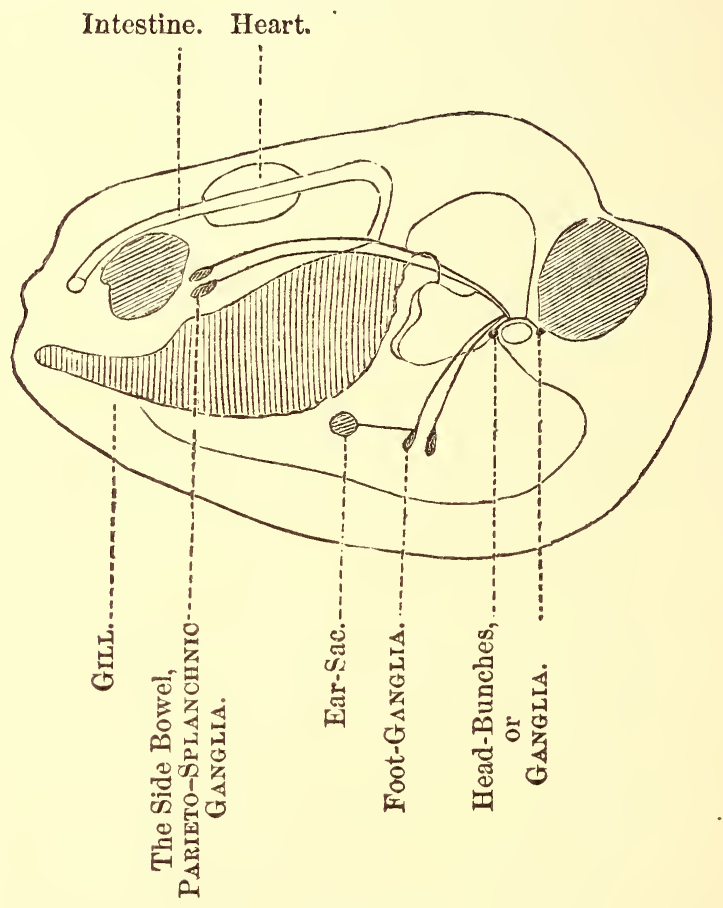

know lies in the foot (Fig. 103). The brains, or nEADGANGLIA, give off cords, which run backward toward the hindmost strap, or POSTERIOR ADDUCTOR MUSCLE, below which they end in a pair of bunches, or ganglia, called the parieto-splanchnic (Fig. 103), which means 
the side of the bowel-the splanchnic nerve goes to the bowel. These give off nerves to the heart, stomach, liver, and kidneys. The Mussel seems to be very nervous and sensitive, for the least touch or sound disturbs it and makes it close its shell. Now, I fancy you would like to hear about the little anoDons, or the babies of this toothless animal. Well, there are plenty of them, for the Mussels are very old-fashioned sort of folks, and believe in large families; some of them have as many as one hundred and twenty thousand little ones in one season. These babies are the funniest little things you ever saw; you would never imagine they belonged to their parents. They do not resemble at first either father or mother mussel. During the spring-time, if you look at the gill-pockets of the old MUsseL, you will

Fiส. 104.

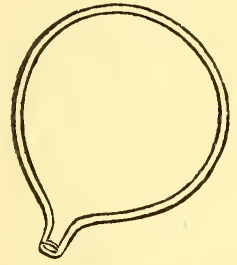

EgG of Mussel.
Fig: 105.

Hinge.

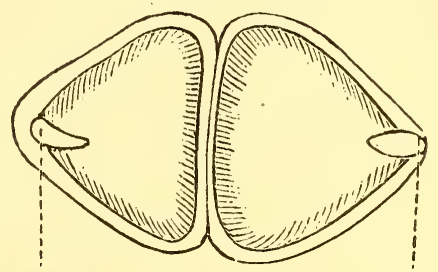

Hook.

Hook.

Shell of Young Mussel-open.

find them perfectly filled with eggs. Each egg looks like a little short-necked bottle (Fig. 104). Here the little Mussels are hatched in the pockets of the gills, 
like chickens in a nest. Each one has his own little MANTLE and shell, and the parts of the shell are threecornered, and at one of the corners is a little hook or tooth (Fig. 105). Hanging down from the shell are a whole lot of fine threads called a Byssus, because they look so much like fine flax, or hemp. This fine rope, or Byssus, is found only in the infants, they drop it when they grow up; but the salt-water mussels keep theirs all their life, and use it as a cable to anchor themselves to the rocks, and they can slip this anchor when they please and throw out a fresh one. Soon after the little ones are hatched they may be found all tangled up in masses, wound about with these fine, flaxy ropes, inside the parent-shell; but they soon untangle themselves and leave their mother's house by the little backdoor, or Dorsal sipion, and they swim about by the flapping of the three-cornered parts of the shell. This looks like a very dangerous move of the Mussel, because it is so very young to make its way in the world of waters. But they are knowing little fellows of their age, so, instead of "paddling their own canoe," they jump on board the first boat that goes past, which happens to be a fish, such as a stickleback or a roach, taking first-class passage, for you always find them at the stern, or tail, of the fish, and they keep themselves from being washed overboard by hooking the little spines, or 
teeth, of their shell into the deck (Fig. 106). While they are thus carried about by this water perambulator, they pass through many changes, and at last become exactly like their parents; then they leave the tail of the fish, and settle down in the mud for the rest of their

Fig. 106.

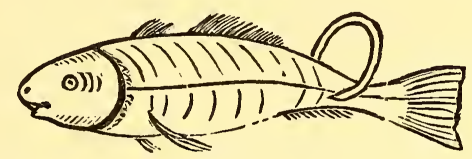

Young Mussel traveling on the TaIl of a Fisi.

lives. The mussel is the most ambitious of all the animals we have yet examined; he makes an attempt to keep a servant for each kind of work, and he succeeds pretty well. As you have seen, he has Muscles, BLOODVESSELS, NERVES, EARS, HEART, MOUTH, GULLET, STOMACH, intestines, LIVER, and kidneys. He lacks only a few things, such as head, eyes, teeth, backbone, etc., to lift him into a still higher class. All this we have learned about a little creature which looks at first sight like a mere bit of slimy flesh. The house itself is a very pretty piece of architecture; I hardly know what style to call it. Its arches suggest the "early Roman." It is sometimes called the skeleton-you remember the leaf of the bean had a skeleton; but the soft parts of the leaf lie between and over the parts of the skeleton. The Mussel's or ANODON's skeleton lies outside its body, 
and so it is called an exo-skeleton. You, too, have a skeleton, or framework, but yours lies inside your body, with the soft parts outside, and so yours is called an ENDO-SKELETON, or inside skeleton. In describing the animal himself, I pointed out the straight Dorsal and the curved ventral edges, also the large ANTERIor and the pointed or smaller Posterion ends. Along the lower veNTRAL edge of each VALVE, or half of the shell, you will notice a rim that is softer than the rest of the shell. When we study how the shell is formed, we may find out why this part is soft. On the upper, or DoRsaL,

FIG. 107.

Umbo, or Knob.

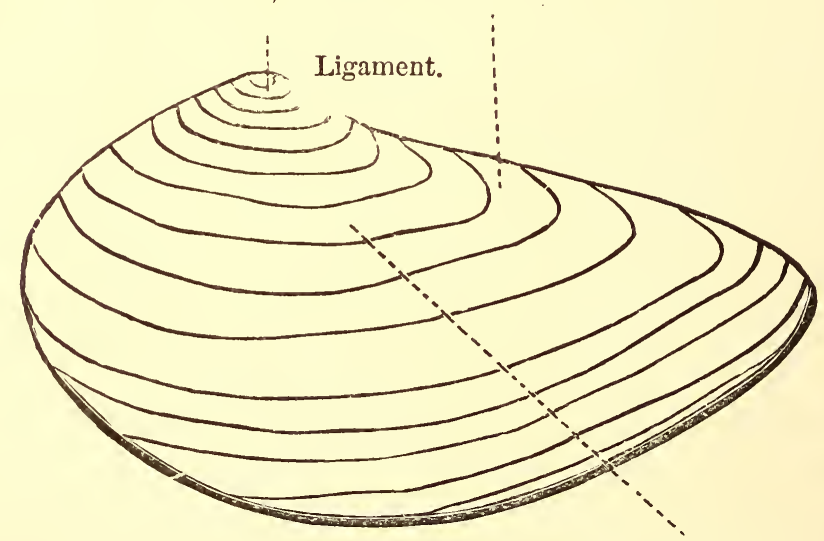

Lines of Growth.

edge of each half-shell, or valve, is a clear, shining little knob called the шмво (Fig. 107), because it stands out like the boss, or central part, of a shield. Behind 
the shiny knobs - the umbones - is an elastic band which lies between the two valves, and joins them together, and hence it is called a Ligament (Figs. 107, 108). This

Fig. 108.

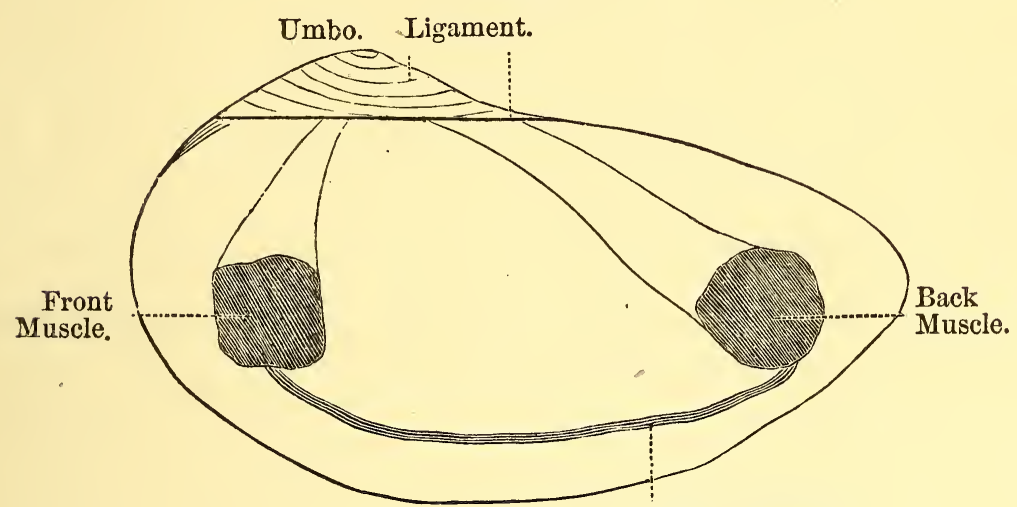

Edge of Mantle.

elastic band is always on the stretch when the ADDUCTor muscles close the valves, or folding-doors of the shell; but, when these muscles are cut, the band springs back or shortens itself; thus the shells of dead Mussels always stand open. The outside of the shell is covered by a kind of a skin, of a greenish-brown color, and this skin prevents the water from wetting the lime, of which the shell is made. All over the shell you can see lines, or arches, and these increase in size and number toward the lower, or ventral, edge (Fig. 107). The upper lines seem to overlap the lower, and the shell becomes thinner at the ventral side. The inside of the shell is white 
and shining, and this white substance is very useful ; it is called "mother-of-pearl," and is made into knife-handles, buttons, and many kinds of ornaments. On the inside of the valve you can see two three-cornered, or TRIANGULAR marks, where the POSTERIOR and ANTERIOR ADDUCTOR MUSCLES are fastened (Fig. 108). These two marks are joined by a curved line, which shows where the muscles in the edge of the mantle are fastened (Fig. 108). From each ADDUCTor Muscle you can trace two faint lines, getting nearer and nearer together as they go toward the shiny knob, or чмво (Fig. 108). These lines show where the ADDucrors, or straps, used to be attached. You will understand how these marks are made when you see how the shell grows. At first the shell is just the size of the little nussen, but as he grows he needs more covering, so he puts out another layer from the outside of his outer skin, or mantLe. This layer, like the first, gets hard from lime which fills up its openings. Its upper edge lies under the lower edge of the first layer, like the shingles or slates on the roof of a house, and this lapping makes the first ring which you see on the outside (Fig. 107). By-and-by the house gets too small again, and the third row of shingles is added to the roof, and so on till you come to the last row, which you find is soft. Now you know the reason why this is soft; it is the last layer, and is not yet filled with 
lime. When any thing is made hard by lime, it is said to be CALCIFIED-CALCIUM is the chemical name for lime, so the last soft ring is said to be UNCALCIFIED, that is, not filled and hardened by lime. Now all these lines are called lines of growth (Fig. 107), because they show the age of the ANODON, just as the rings of wood in the trunk of a tree show the age of the tree. When the young Mussel was away up under the little roof, close to the knob, or UMBo, its straps, or ADDUCTOR MUSCLES, were fastened up there too, but, as it moved down and became larger, it had to move its muscles with it, so that it kept taking up and putting down the fastenings of the muscles whenever it made a move forward, and each fastening left a mark on the inside of the shell. So now you know how the triangular marking (Fig. 108) is made inside from the top to the bottom of the shell. You can make the same shaped marking in the sand, if you place your heels together and then step forward, placing your heels farther apart at each step. Where you start represents the umbo; where you stop represents the bottom of the shell. So the little mussel steps forward, leaving the print of his straps as he goes. Some of the shells of the Musser family grow to an immense size, weighing as many as six hundred pounds. When you go to Paris you can see a pair of clam-shells weighing five hundred pounds, which are used to hold 
the holy water in the Church of Saint-Sulpice. Some of this family, living in the rivers of Scotland and Wales, and in the Persian Gulf, produce small, hard, shining, round, or egg-shaped bodies. Some of these lie on the inside of the shell, but the prettiest and largest are found inside the MANTLE near the straps, or ADDUCTOR MUsCLEs. They are so bright and beautiful, that they are called jewels. You have often seen them and know their name, but perhaps you have never thought where they came from. People used to tell all sorts of stories about them. As wise a man as Pliny thought they were made out of the dew of heaven; others said they were drops of pure rain, which the Mussel opened his shell to receive. But science teaches that the hearenly pearls have a very earthly origin. The animal makes them by trying to heal a wound in his body, or to rid himself of a foreign substance that gets into his shell, such as a grain of sand. It is said that the pearl fishers sometimes catch the Mussels, and wound them by pricking them with needles, and then throw them back into the water. The poor creature throws out a substance to heal its wound, and this substance forms the pearl. Some of them seem to be made of the little eggs which are left in the Mussel's body; thus you see to what a very useful family our friend belongs. Besides this power to make pearls, many of them are de- 
licious food. The oysters you like so well are near cousins of the mussel. Now, when you are enjoying your nice Baltimore or Saddle-rock stew, you will often think of the pretty fringed mantles, the little rooms, and the funny pockets. Clam-chowder is a celebrated dish, and many people think it rare fun to have a clambake on the sea-shore. Cockles, too, are a favorite food. I have often seen women and children gathering them on the sands on the coast of Scotland, when the tide was out. The cockle buries himself quite out of sight, but you can see the hole he leaves in the sand above him. In the old country, people eat cockles as we eat oysters. The way in which these poor things are cooked alive is very cruel. The people who roast the oyster and cockle in his shell by the hundred think it very wicked to cut one or two up to find out how they are made. It is not cruel to torture them in order to eat them, but it is very wicked to open them to learn about them! So the people think who love eating better than learning, but I hope you will never torture any animal, either to get food or knowledge. I have told you only a few of the many wonderful things there are to learn about the MUsser, and I hope you will try some day to find out all the rest for yourselves. 


\section{CHAPTER VII.}

THE LOBSTER.

How the Boys and Girls found him to be a Strategic Warrior, a Great Civil Engineer, a Skillful Surgeon, and a Scientific Mover.

ONe day, when I was a school-girl spending my vacation in Baltimore, I went to one of the great fishmarkets, where I saw a jolly old woman in one of the stalls, busily at work with a lot of queer-looking animals that I had never seen before. They had immense claws, which she was fastening together, doing it so easily and rapidly, that I stood looking at her in astonishment. She had such a friendly, good-natured face, I ventured to ask her what she was doing. She was greatly amused, and at once wanted to know where I had been brought up. I told her on the prairies, where we never saw such things. "Law me!" said she, " don't you have lobsters out there? These are lobsters, and I'm fastening their claws to keep them from pinching. They are awful things to pinch. I take one claw so, and the other so, up over his back, and then he can't 
help hisself. Is this your first visit to Baltimore?" Then turning to my friend she said, "You must take her to the top of the monument." I thanked the kind old creature for her information, though I could not quite understand the relationship between her and the monument; but I afterward learned that the top of the monument is the highest expression of Baltimore hospitality among all classes.

I never saw the old woman again, nor did I again see any lobsters, except in the shape of salad, till one morning, not long ago, I found one on the professor's table in the lecture-room at South Kensington. Then I thought of where I saw my first lobster in the Baltimore market, and how the old fish-monger laughed at my ignorance and wanted me to see the monument. When you first try to study the lobster, you will perhaps think as I thought, "How can I ever straighten out such a queer crusty, clawy, lanky, linky, leggy-looking thing as that?" It seems to be made up of all sorts of odds and ends, regardless of expense or plan. You will have no idea where to begin or where to stop. But though the lobster looks as hard as compound numbers or the Greek alphabet, he is as easy as simple addition or you own A, B, C, when once you find him out. You know the corolla, or crown, of the bean looked so hard, but it all came out nicely into five leaves, or PET- 
ALs, as soon as you knew how. Now let us see if we can find and name the different parts of the lobster. There is no kind of use in attempting to do any thing with it unless you have a real lobster before you to look at while I talk. The crawfish, or crayfish, that lives in creeks and rivers, is made in the same fashion as the lobster, only smaller, so one of these will answer just as well (Fig. 109). One thing is very certain, he has a great many different parts, and these, as a rule, are very unlike each other. First, you see he is covered with a shell, which, like the MussEL's and cLam's, is his ExoSKELETON. This shell is very hard like stone, and it is colored purplish black, with pale spots here and there; you can hardly tell it from the color of the rocks among which the LoBster lives. The LoBstens which you see in shops are always dressed in scarlet coats, or shells. When these poor fellows are caught they are plunged alive into boiling water, which turns the black coat red. This outside shell, or Exo-skeleton, is made up of a great many different pieces instead of two as the musSEL's; but those pieces are shaped and joined in such a way as to make three divisions of the body-a HEAD, a THoRAx, or breastplate, and an ABDomen. The headpiece of the shell is pointed in front, forming the BEAK (Fig. 109), or frontal spine. Behind this head-piece is a groove, or seam (Fig. 109), where the head joins the 
Fra. 109.

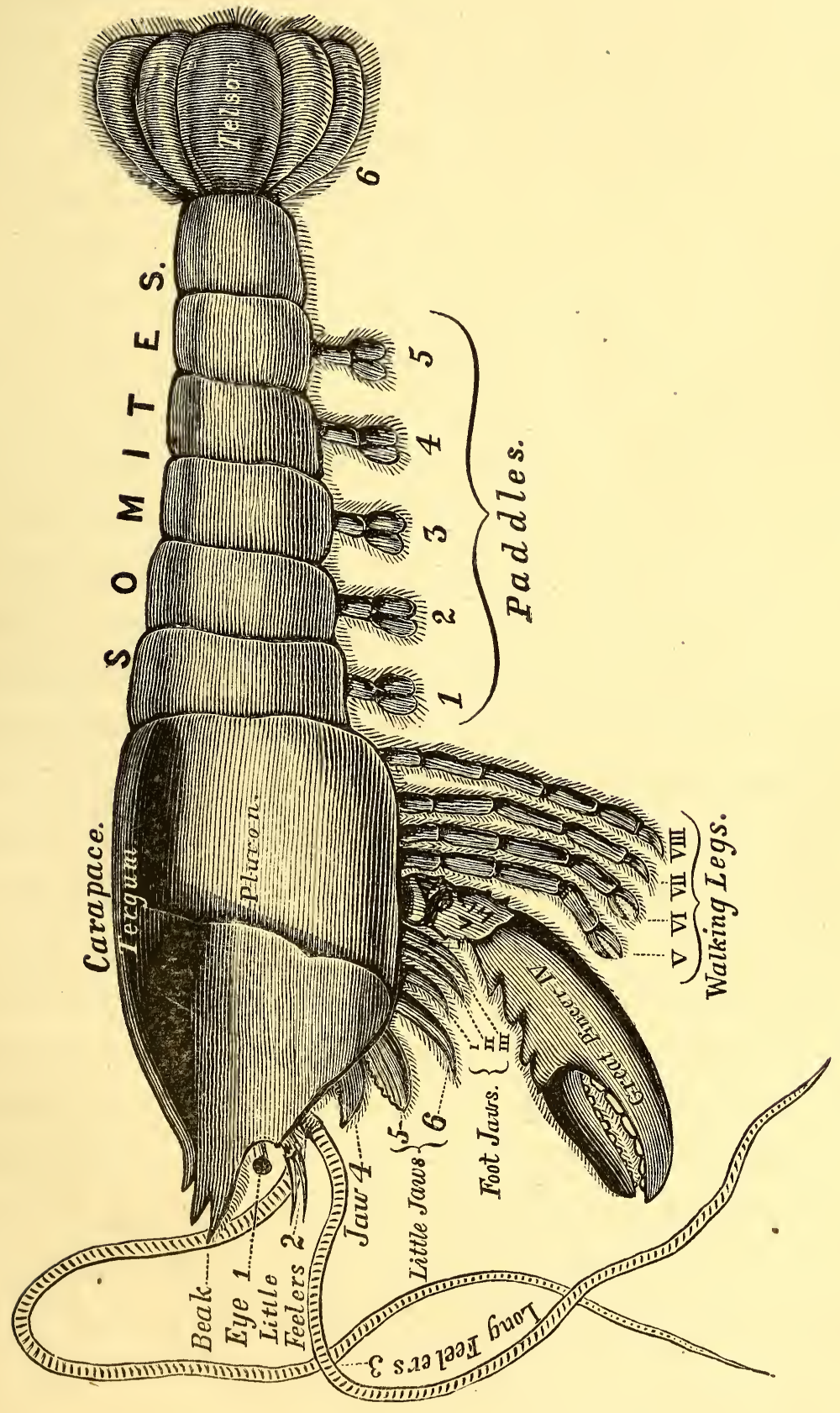


breast, or THORAx, making the two pieces of shell which cover the head and breast all one. So the first and second division of the body, thus joined in one, are called the CEPHALO-THORAX, or head breastplate. The large piece of shell, with the seam that covers the back and sides of the CEPHALO-THORAX, is called the CARAPACE, or shield (Fig. 109). It is the front sharp point of the shield (CARAPACE) that is called the FRONTAL SPINE, or beak. Behind the head and breast-CEPHALO-THORAX-lies the third division of the body, the ABDOMEN, which is made up of seven pieces, or joints; the first six joints are called somites (Fig. 109), or bodies, and the last joint, or tail-piece, is called a TELson, which means end. So the body of the lobster is made up of six body-pieces, or somites, and a tail-piece, or TELson. Each body-piece has a pair of soft-jointed paddles on its under-side, and these are called swIMmerets, or little swimmers (Figs. 109, 116). The lower joints of these paddles have two broad, flat toes. The paddles on the last, or sixth, soMITE are different from the others; they are wider, and turned backward (Fig. 116), so as to lie at each side of the tail (TELSON), and these great fringed paddles, taken with the TELson, form what is called the tail-fin, from its likeness to the tail of a fish. The under or VEnTraL part of each somrte, or body-piece, which lies between the paddles, is called the sternum (Fig. 110). The 
rounded upper or DoRsal part of the body-piece is the Tergum, which means the back. Perhaps the body-

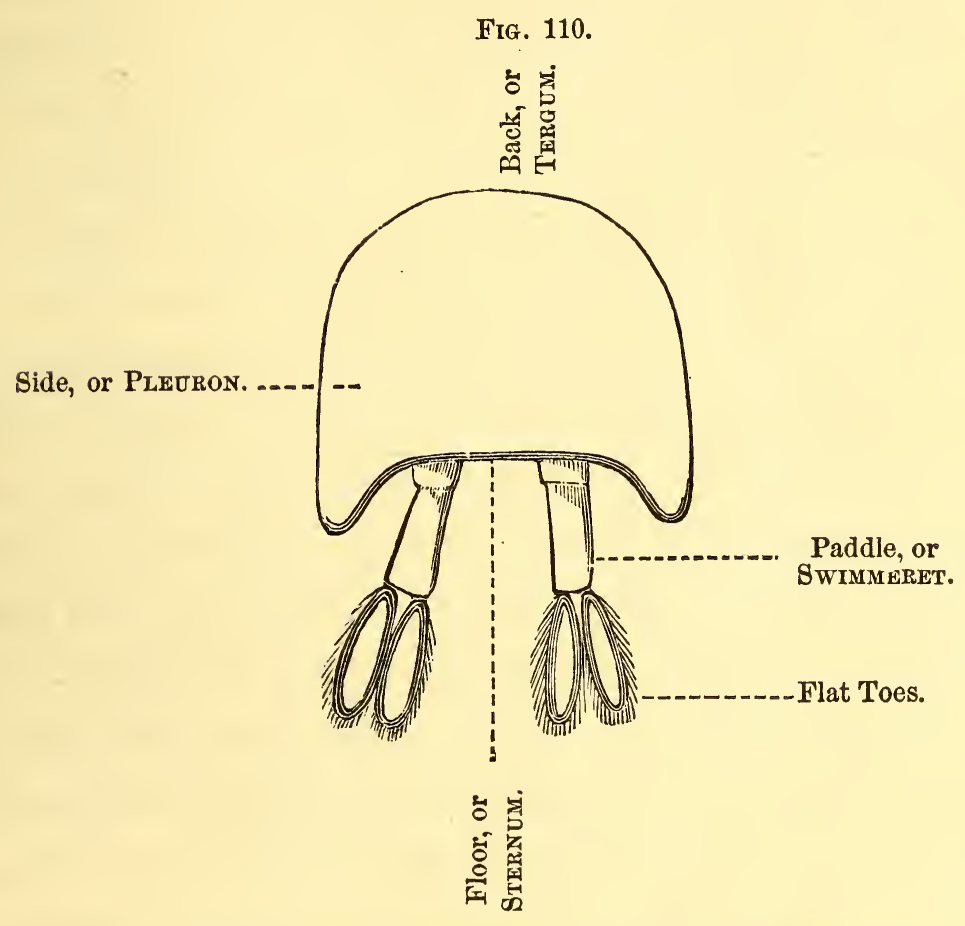

ONe of the Lobster's Body-Pieces, or Somites.

pieces (somites) with their joints and paddles, may bring to your mind the stem of the bean with its knots, or NODES, INTERNODES, and leaves. In front of the ABDOMEN, with its somites, is the cephalo-thorax. This head breast-plate, or CEPHALo-thorax, has a tergum, or . back part, a STERNUM, or under part, and a PLEURON, or side part (Fig. 109), and so many things are hanging down 
from it, one can hardly count them all, much less learn them. Counting from behind forward, you will find between the lobster's body, or abdomen, and the head, eight pair of jointed legs or arms, or both, one pair much longer and larger than the others, with huge pincers (Figs. 109, 116) at the ends. All these eight pair are called the THORACIC APPENDAGES, because they are fastened to the THORAx, or breastplate. The lobster uses the four back pairs for walking, and so they are called the ambulatory limbs. Amble means to walk. The last pair has seven joints, and every joint works in a different direction, so when these hind-legs start off it is hard to tell where they intend to go. The next pair of walking-legs are like the hindmost pair, except that the first joint sends out a piece above it which is kept out of sight in a little room in the side of the lobster (Fig. 116). We shall hear more about this little room by-and-by. The two front pair of walking-legs send up pieces also into this chamber, but the end of the leg is different from the last two pairs, for they have pincers, or Chele (Fig. 109). Now we have come to the longest pair; the CHELE, or pincers, at the ends are so large and strong, that they are called the GREAT CHELA (Fig. 109). These are the pincers that the old fishwoman fastened, and they are the LOBSTER's weapons of defense. He is a queer soldier, and has introduced 
some original tactics in the science of war. When he is taken prisoner, that is, seized by one of his claws, he quietly leaves the claw in the hands of his astonished captor and beats his retreat as fast as possible. Thus does he surrender his sword without giving up his person. He has another odd way of laying down his arms when he is frightened by a great noise, such as thunder, or the firing of a cannon. It is no uncommon thing to find a number of these broken swords lying about among the rocks, showing where there has been a LoBster fright or fight. Perhaps our hero would not be so ready to drop his sword and run if he were not sure of getting another. As soon as one claw goes another takes its place, but it is some time before the new one gets as long and strong as the old one; so you may see all sorts of disabled soldiers in the LOBsTER army, some with no arms, some with one, and others with one arm shorter than the other. You will notice quite a difference between the two large claws, or Forceps. In one the teeth are large and blunt, and in the other they are very sharp (Figs. 111, 112). It seems that they are not made for the same use. The blunt-toothed pincers the LOBSTER uses as an anchor to moor himself, while with the other he attacks and seizes his prey. - So much for the great claws, or CHEL瓜. The next three front pair are called MAXILLIPEDEs, or foot-jaws (Fig. 109), because 
they act both as teeth and feet. The hindmost foot-jaw has three divisions, or branches; one branch passes up into the side-chamber of the lobster. The middle branch is long and jointed, and it, with its fellow on the other

FIG. 111.

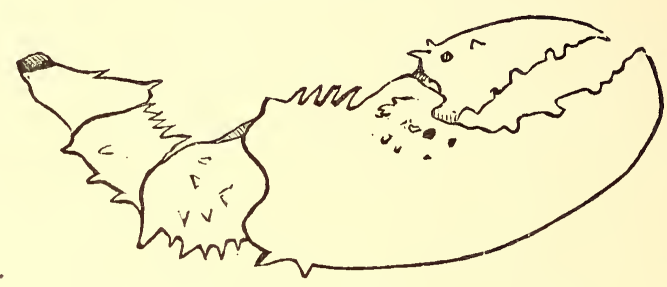

Large-toothed Claw.

side, acts as a pair of scissors, cutting food for the mouth. The third branch is jointed and is a walking-leg. The middle foot-jaw (MAXILLIPEDE) is much like the last, while the front one does not send a piece upward into

FIG. 112.

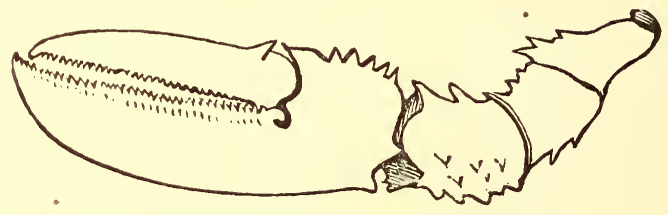

Small-toothed Claw.

the side-chamber, and one of its branches is flattened out so as to look like leaves. The four walking-legs, the great pincers, or CHELe, and the three pair of footjaws (MAXILLIPEDES), making eight pair in all, belong 
to the lobster's breast, or thorax. Now we come to the head, which is provided with six pairs of hangers-on, or APPENDAGES. The two back pair belonging to the head are called MAXILLE, because they lie at the side of the mouth and are like jaws. The hindmost of the jaws, or MAXILLE, on each side has a boat-shaped or oval plate, which lies at the front entrance of each of the two side-chambers, about which you will hear more presently. The ends of the front pair of little jaws (MAxILL\&) are leafy, like those of the front pair of foot-jaws (MAXILlipedes). Now we come to the jaw itself, or mandible (Fig. 109). You see it has strong teeth, and bears a small APPENDAGE-the PALP. The true jaws (MANDIBLes) lie at the sides of the mouth (Fig. 109). From all this you see that the mouth of the LOBSTER is well armed with teeth and scissors, to tear and cut its food. Counting from the front, it has first the true jaw (MANDIBLE), then the two pairs of little jaws (MAXILLA), and these are followed by three pairs of footjaws (MAXILLIPEDES), altogether six pairs, which are all turned up against the mouth, making the old fellow look as though he had the toothache. In front of the jaw are two very long-jointed feelers, called ANTENnes (Figs. 109 and 113); but you seldom see them at their full length, for they are easily broken. Next to the feelers (ANTENN $\approx$ ) are two little feelers, or ANTENNULES 
(Figs. 109 and 114), and last of all, in front come a pair of joints which support the eyes (Figs. 109

FIG. 113.

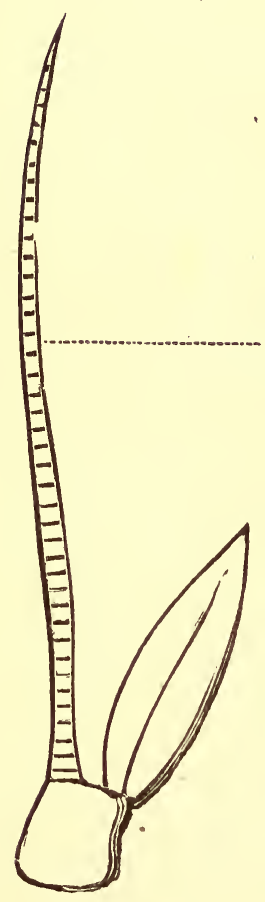

Long Feeler, or ANTENna.

Fig. 114.

Little Feeler,

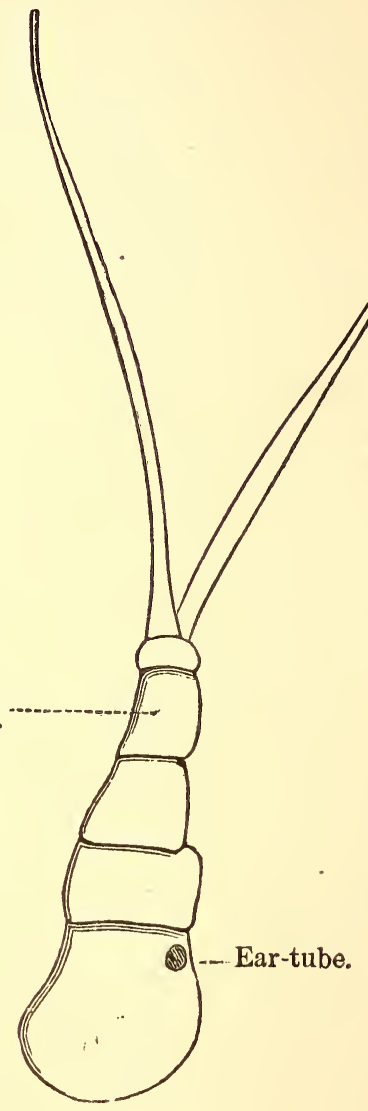

and 115), and hence these are named the optrC PAIR of appendages. Now let us begin with the eyes and go back to the tail, to see how many pairs of feelers, jaws, hands, feet, and paddles, the LoBster owns. He has six pairs attached to the head, eight pairs to the breast (тно- 
RAX), and six pairs to the body (ABDOMEN), in all twenty pairs, and very few of these APPEndages are alike. No

FIG. 115 .

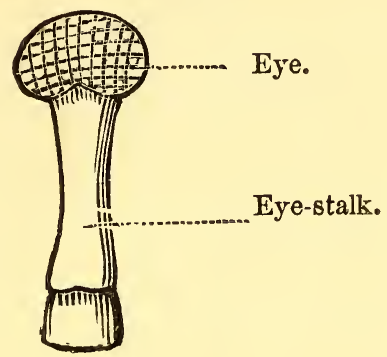

wonder he is called one of the ARTHROPODA, or footjointed race. Arthron means a joint, and pous a foot. I have helped you to count the feet, so you can amuse yourselves by counting the joints. You now

NAMES OF LOBSTER'S APPENDAGES.

i $\int$ I pair.... Eye-stalks.

II “. 6. ANTENNULES, or small feelers.

III " $\ldots$ ANTENNE, or long feelers.

IV “ $\ldots . .$. Mandibles, or true jaws.

$\left.\begin{array}{c}\text { V } \\ \text { VI }\end{array} \ldots \ldots\right\}$ MaxıLLE, or little jaws.... $\begin{aligned} & \text { First pair. } \\ & \text { Second }\end{aligned}$

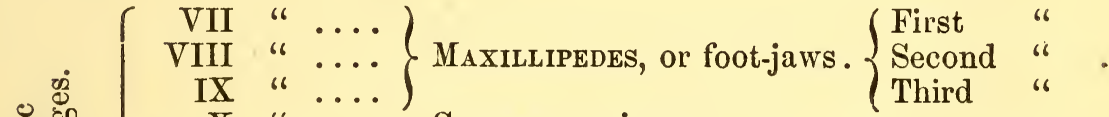

X $\quad$ “... CHELE, or pincers.

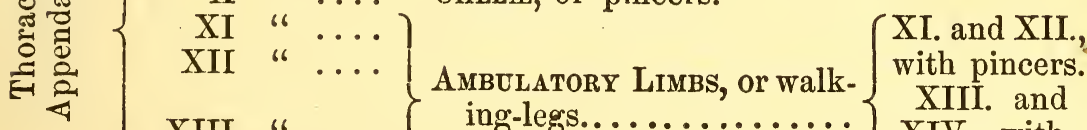

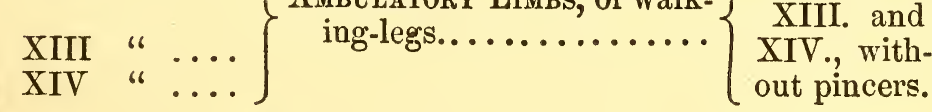

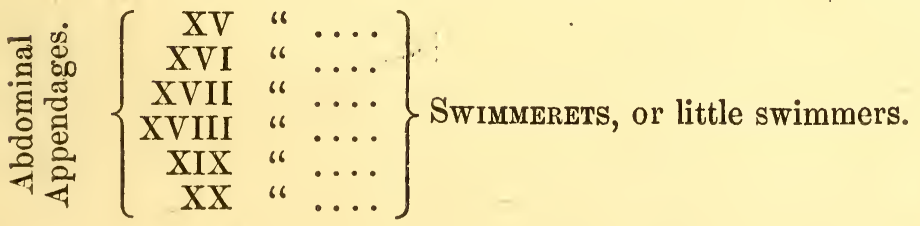


Frg. 116.

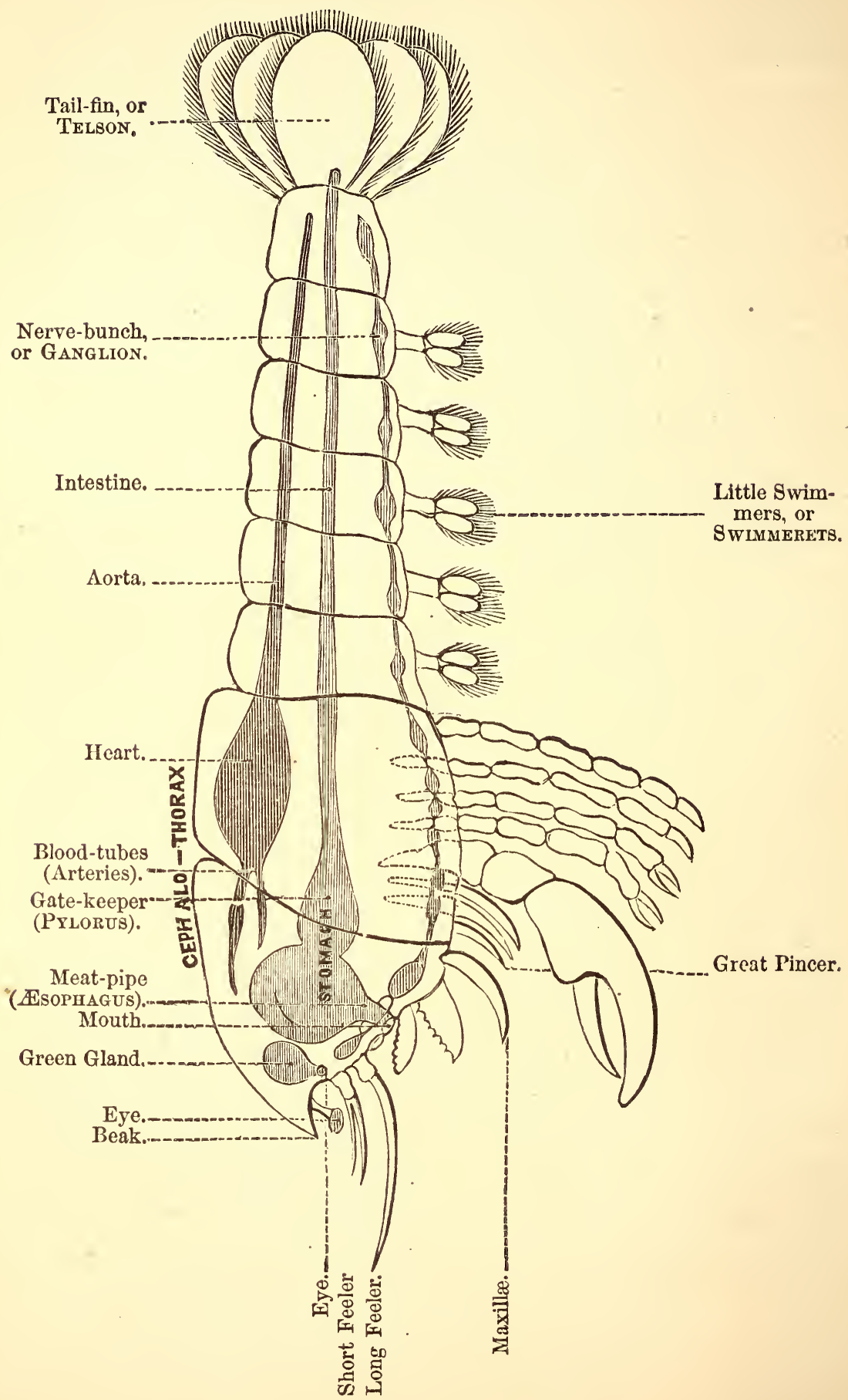


have a pretty good idea of the Exo-sKELETON, or hard outside part of the LOBSTER, and we shall look next at the soft parts inside. The mouth seems a very good place to begin at, and you will find it between the MANDIBLES, or jaws (Fig. 116). In front of it is a lip shaped like an ESCUTCHEON, and it is called the LABRUM, which means lip. At the back of the mouth is another lip, the metastoma, from two words, which mean beyond the mouth, and this has been looked upon as the lower lip. The mouth, as in the mussel, opens into a gullet, or cesophagus (Fig. 116), and this into a four-cornered box-the stomach-which is very curiously made. Near the centre of the box, or stomach, the walls come almost together, dividing it into two parts: the front part is the larger, and it is called. the caRdiac end, because in the HUMAN HEART the upper end of the stomach points toward the heart, hence it is called the heart, or CARDIAC end; but you see in the lobster it points away from the heart. It contains three strong colored teeth, fastened to a T-shaped frame (Fig. 117), and worked by muscles which are fastened to the inside of the breastplate (CARAPACE). These teeth meet in the middle of the stomach, and form a powerful grinding machine, which crushes the food like the stones in a. mill (Fig. 118). Often when you find the empty shell of the lobster on the sea-shore, you can see a perfect 
FIG. 117.

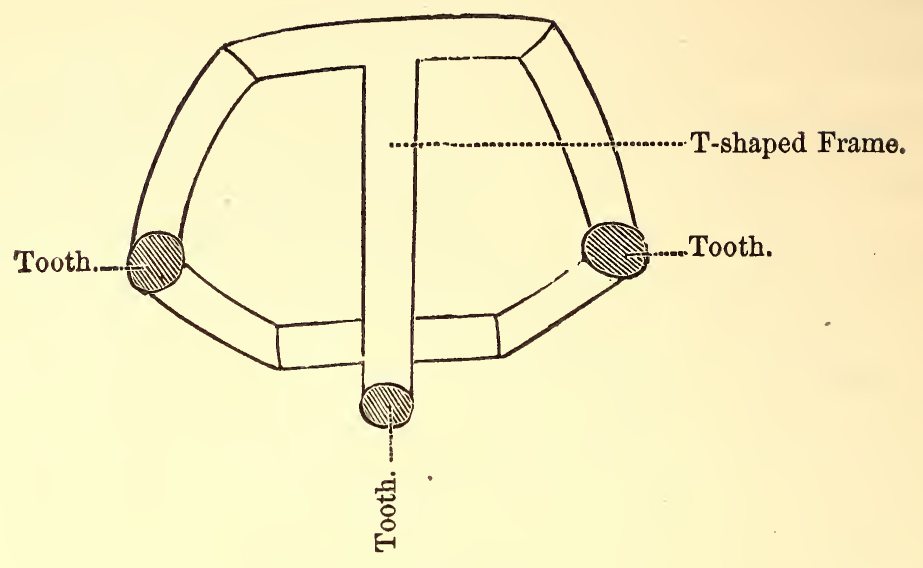

The Lobster's Milt.

mould of this T-shaped mill; it is sometimes called "the lady in her chair," because some one fancied it Frg. 118.

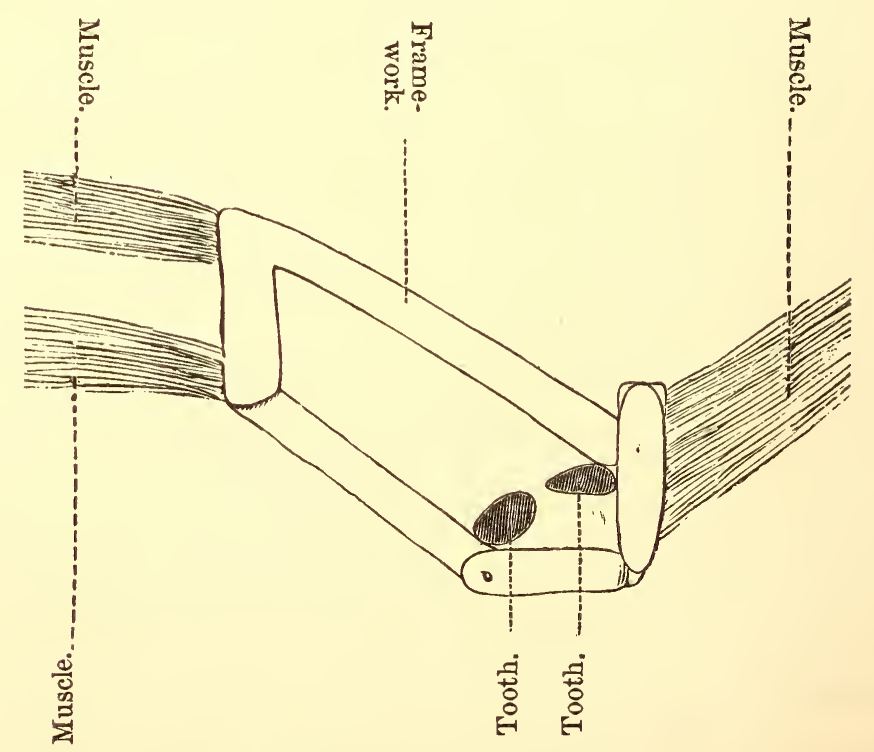

The Mill and its Muscles. 
looked like a lady in a chair. How the LOBSTER gets out of his shell, and how he turns the mill out of his stomach, we shall study after a while. The small back part of the stomach is called the PYLORIC end, and it is made inside like a sieve, or strainer. The inner sides are stuffed out like cushions, almost meeting in the centre, and quite covered with hairs (Fig. 119). Let us see

FIG. 119.

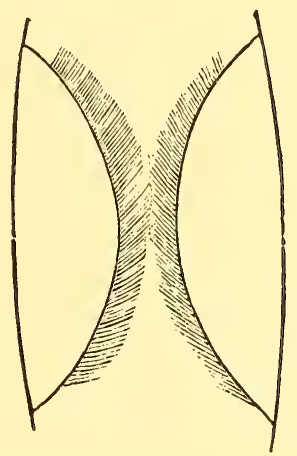

The Hairy Cughions at the Small End of the Stomach, through which the Food is STRAINed.

why. PyLonus means gate-keeper, from two Greek words, which mean gate and guardian. The PYLoRus of the stomach keeps watch and guard over the INTESTINE; its business is to protect the INTESTINe from all intruders, such as big pieces of meat and hard bodies. None but the finest particles can pass through this cushion-like strainer, and hence the PYLORus is a first-rate gate-keeper. The very hard parts of the food, which 
are of no use to the LOBSTER, are sent out again by the wide mouth of the stomach. It is very interesting to know that there is hardly a machine that man has invented, but something like it, though usually much better, may be found in some animal. The LoBster's . stomach is a perfect machine for grinding and straining, and it will repay all your trouble if you take a peep at it in the LOBSTER itself. When you begin to look for the stomach you must go to the head instead of the body, or ABDomen. Why the Lobster should have such a perfect mill and strainer is at first hard to understand, because he is not at all particular or dainty as to his food; he is a regular scavenger, and feeds upon all sorts of refuse and carrion. But the little gate-keeper (pylorus) opens the way into a very thin, delicate tube-the intestine, and, on account of the extreme fineness of its walls, it is of the greatest importance that the gate-keeper prevent any of the coarse abominations on which the LOBsTER feeds from entering the INTESTINe; hence you see the necessity of the mill and strainer. The intestine does not go wandering about in the body like the MussEL's, but passes straight back (Fig. 116) and ends at the ANus; on the under part of the tail-piece (TELSON). On each side of the head breastplate (cephalo-thorax) lies a long, soft, yellowish, green mass. This is the LIVER, and it opens into the 
small PYLORIC end of the stomach by several ducts or pipes on each side. The LIven is large enough to make our friend feel very melancholy, but we never hear of his committing suicide. Away up in the front part of the head breastplate (CEPHALO-THORAX), at the base of the feelers (ANTENNE) on either side, you may

FIG. 120.

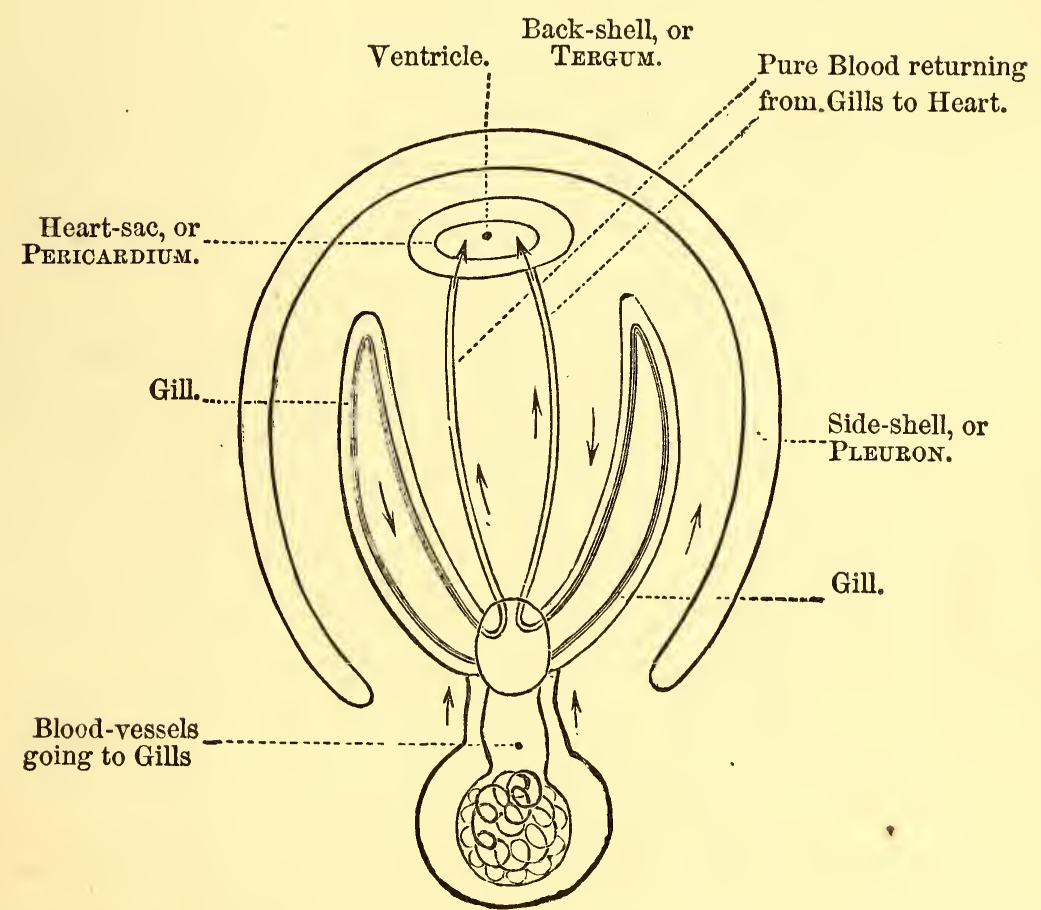

A Cut, or Section, of Lobstér, showing the Course of Blood throdgh the Gills to the Heart.

see a soft, green mass, called the GREEN GLAND (Fig. 116). This is supposed to be the KIDNEY, and it opens 
by a tube at the side of the feelers (ANTENNE) toward the mouth. A bristle passed through the opening will enter the "GREEN GLAND." It has been quite a puzzle to know the use of these glands; at first they were supposed to be the Lobster's ears. Next we will take a look into the side-chambers of the head and breast (CEPHALOTHORAX) and see what the three pair of walking-legs, the great pincers, or CHELe, and the two pair of jawfeet, are doing in there. In each chamber we find eighteen little tapering, feathery-like bodies (Figs. 120, 121).

FIG. 121.

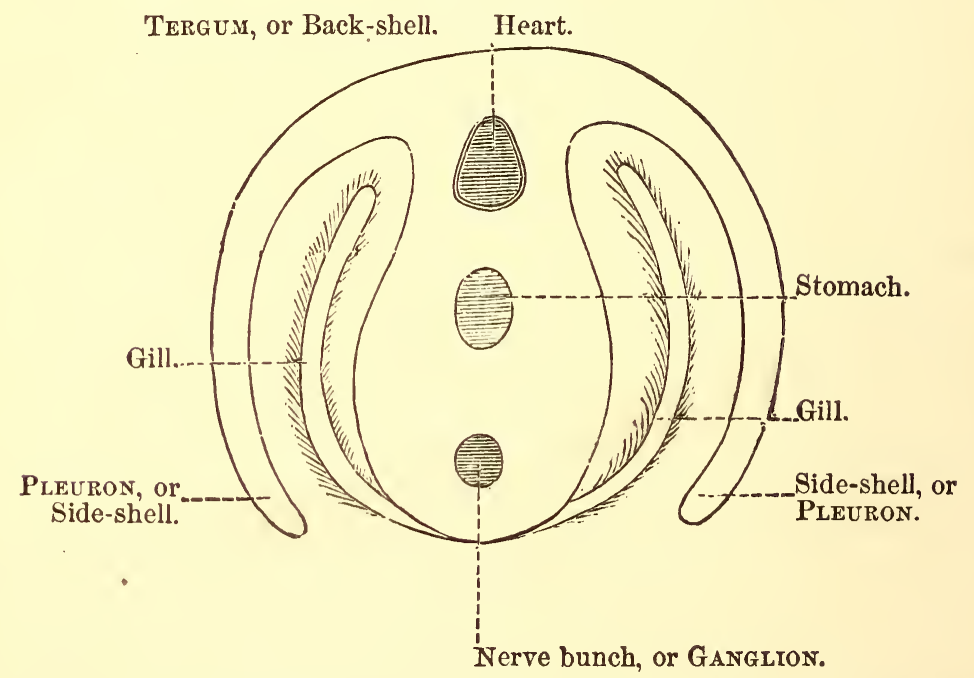

Cut, or Section, of Lobster, showing the Position of Heart, Stomach, the Cirain of Nerves, and Gills.

Each has a central stem surrounded by fine, feathery filaments; they look very much like so many little bot- 
tle-brushes. These are the GILL-PLumes, and this room is called the GiLl or BRANCHIAL chamber. Branchial comes from the Greek word meaning gills. The GILLS are placed in two sets, six in one and twelve in the other. The first row are fastened to the six feet, or APPENDAGES, of the breast (THORAX), which we found pushing themselves up into the chamber (Fig. 116); the other twelve are fastened to the PLEuRon, or sidepieces, of the cephaLo-thorax. These gills are not covered with stiff hairs (CILIA) as the mussel's, so there must be some other plan of moving the water. Let us see if we can find it. There is a very curious piece of machinery at the front entrance. You remember the oval or boat-shaped plate in front of the chamber, formed by the hindmost little jaw (MAxILLA); this plate is called the scapHo-gNathite, which means the little skiff-like jaw. It is made on the plan of the archimedean screw, and it works as the screw of a propeller, and is set in motion by the jaws. The water enters the back part of the GILL-CHAMBER by a slit, and it is scooped out by this screw through the opening in front, bubbling and frothing as it goes. Thus the mechanism of the screw was all worked out in our little LOBSTER long years before it was discovered by the great Archimedes. The tiny net-work of the blood-vessels is spread over the framework of the GILL-PLumes, just as 
you found it on the lattice-work of the MUSSEL's GILLPockets. As the screw scoops the water through the BRANCHIAL Or GILL-CHAirber, the blood takes out the OXYGEN from the air in the water and gives back CARBONIC ACID. You remember how the strong hairs (CILIA) of the pockets sweep the water along over the Mussel's GILLs, and how the little blood-vessels take up their OXYGEN and give up their CARBONIC ACID. The GILLs that are fastened to the legs, or limbs, move when the limbs move, and the faster they go the more water they use, just as the faster boys run the more air they must have; so the more pure water for the LOBSTERS and the more pure air for the boys, the purer and the better the blood for them both. So much for the LoBSTER's breathing, or RESPIRATION. Next we will study his circulation. His blood must move, else it would not get in and out of the GILL-PLumes. Beneath the head-shield (CARAPACE) and behind the seam which joins the shells of the head and breast, you will find another chamber; it lies just behind the stomach (Fig. 116), and between the gill or BRANCHIAL CHAMBERs. This is the heart-sac, or PERICARdIum. You remember you found one in the Mussel. In the heart-sac, or PERIcardium, lies a six-sided sac (Fig. 122), and this is the heart. It has but one room-no AURICLES like the musSEL's-nothing but a VENTRICLE, which is slung in the 
PERICARDIUM by straps, or Muscles. The heart is not hollow inside like a bag, but is nearly all filled up by its own thick, spongy walls. There are six openings

FIG. 122.

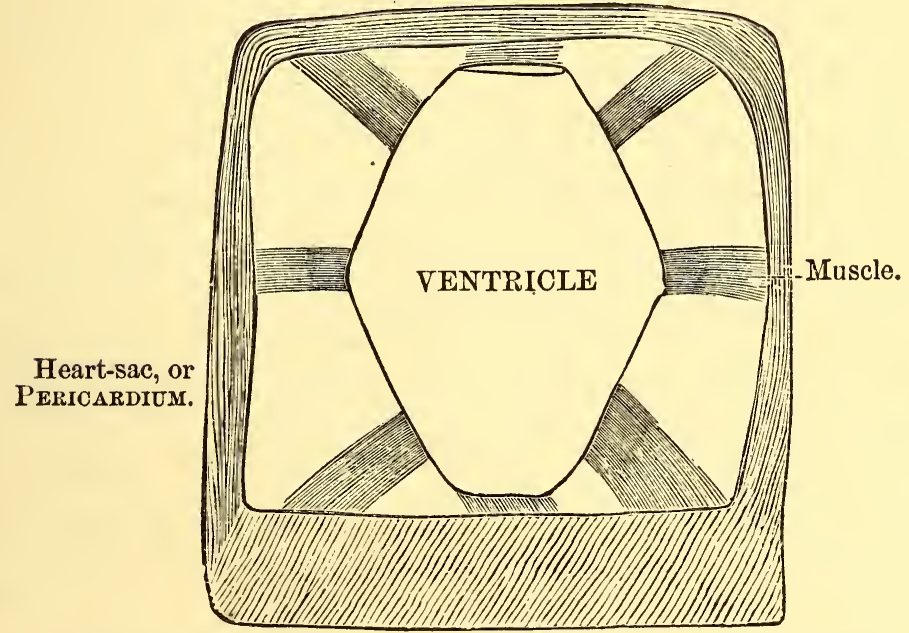

The Lobster's Heart slung in its Sad by Straps, or Muscles.

leading into the one room, or VENTRICLE, from the outer sac, or PERICARDIUM. These openings, or doors, are guarded by little vaLves, which allow the blood to pass inward, but prevent its return. The ventRicle gives off six tubes, or ARTERIES, five in front and one very large one behind (Fig. 123); these arteries divide into smaller ones (CAPILLARIES) which carry the blood all over the body. While the blood is passing slowly through the fine hair-tubes (CAPILLARIES) it gives up its oXYGEN and nutritious matters to feed the body, and re- 
ceives the waste fluids and CARBONIC ACID. Now the blood must be taken to the GILLS to be purified, and so it is collected from the hair-tubes (CAPILlaries) by the

Fig. 123.

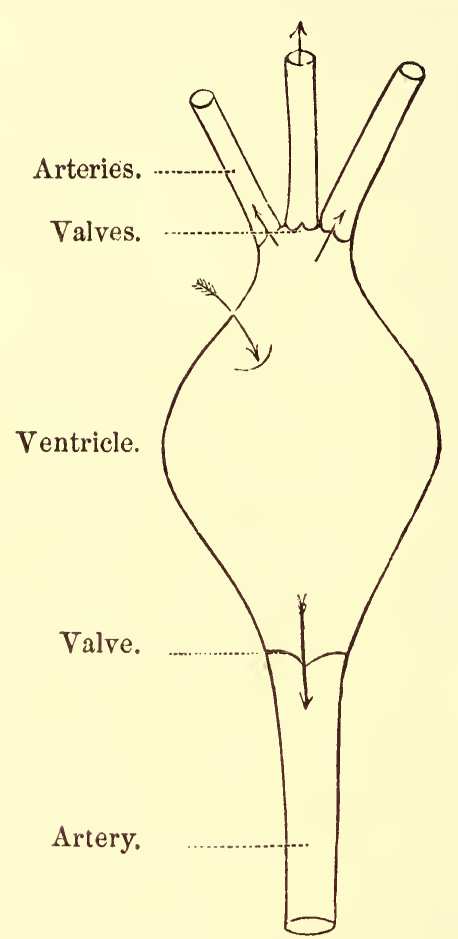

Heart and its Vessels.

veins, which carry it to the blood-chambers in the breast, or THoRAx. The blood-chambers then send the blood to the GILLS, where it is distributed and AËRATED, or purified, through the fine net-work of the GILLs. From the GILLS it is carried by ressels into the heart- 
sac, or PERICARDIUM, thence through the little valves into the ventricle (Fig. 120). The blood is next forced into the large tubes, or ARTERIES, by the contraction or squeezing of the ventricle, as in the Mussel's heart. When the lobster is out of the water the ventricle beats about thirty times a minute, but it beats much faster when in the water (about fifty times a minute). After the blood has been deprived of oxyGeN, it moves slowly and the amount of CARBONIC ACID it contains makes the LOBSTER insensible. You know, if you stay in a room where the air is bad, you feel yourself getting sleepy. You and the LOBSTER are in a state of what is called ASPHYXIA, meaning without a pulse.

The LoBster's blood is colorless when living, but when dead it makes a purplish clot. The blood-cells look much like the HUMAN AMœB开; they are colorless, contain little grains, and show the same crawling movements. The LoBsten will bleed very freely with only a slight wound, because the blood-vessels are so wide and loose. One might think he would bleed to death when he so carelessly throws off his limbs; but the lobster is a good surgeon, he always takes care to cut off, or AMPUTATE, at a joint where the vessels are narrow, and when he gets wounded in a limb he amputates it at the joint above the wound. The joint acts as a surgeon's bandage and soon stops the bleeding. Thus surgeons 
as well as mechanics can learn from the LOBSTER. So much for the heart and its circulation. The LOBSTER is well supplied with nerves; in front of the gullet you will find his brains, in the form of a bunch, or GANGLION, on each side (Fig. 116); they correspond to the CEPHALIC Or HEAD GANGLIA of the MUSSEL, though they are much larger. Passing back from the nerve-bodies (GANGLIA) you will see white nerve-cords, reaching over the gullet on each side to the floor of the head breastplate (Cephalo-thorax). Here there is a chain of six nerve-bunches (Fig. 116), or GANGLIA, joined by double cords. The first of these bunches (GANGLIA) answers to the foot-nerves, or PEDAL GANGLIA, of the MUSSEL. From the last of the breast, or THORACIC GANGLIA, a single nerve-cord goes back and joins another chain of six ganglia, lying in the floor of the ABDOMEN, one in each somite, and the last one is very large. These are united by single cords, so altogether there are thirteen pairs of nerve-bunches or GANGLIA (Fig. 116); seven in the head and breast (cepHalo-thorax) and six in the abdomen. From these GANGLia, which answer to your brain and spinal cord, nerves pass off to all parts of the body; but your spinal cord lies at the dorsal or back part of your body and your heart in front, while in the lobster these positions are just the opposite (Figs. 110121). You see what a perfect system of nerves the 
LOBSTER possesses. Who can doubt that the poor thing feels pain when he is plunged into boiling water? Of course an animal which has so much machinery, and makes so many motions, must have a great many strong MUSCLES. You know that the ANODON, or MUssel, moved his foot and his shell by means of his elastic straps, or MUSCLES. Some of the strongest MUSCLES in the LOBSTER's body are those that work the mill (Fig. 118). The heart-bag, or PERICARDIUM, is also fastened to the shield (CARAPACE) by strong muscular folds (Fig. 122). The muscles of the body, or ABDomen, are attached to the shell (EXO-SKELETON) and are of two chief kinds, those which bend the ABDOMEN and those which straighten it. Those that bend are called FuExors, and those that straighten are called ExTENsors. By the action of the benders, or FLExons, and the straighteners, or ExTENSORs, the LOBSTER makes its way through the water, and it is greatly helped by the tail-fin. By a single down-stroke of the TELSON the LOBSTER can send itself backward twenty-five feet. But the LOBSTER's MUsCles, besides being very useful to him, are also very useful to us, as the Muscles are the parts of the body that we eat, though I think the doctors would call them more hurtful than useful ; they are of a beautiful pink color, and when you look at a piece of Musche under the microscope, you can see that it is prettily marked by light 
and dark bands (Fig. 124). These are what are called STRIATED or STRIPED MUSCLES, and the most of yours are marked in the same way. The striped muscles are

Fig. 124.

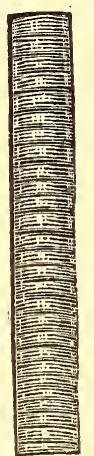

Striped Muscle.

moved by the will, the unstriped are able to move themselvès. You can trace white nerve-cords leading from the nerve-bunches (GANGLIA) to the muscles; they are very large, and because they make the muscle work they are called NERVEs of Motion, or MOTOR NERVES. We do not know just how many senses the LOBster has: he acts as though he had the whole five. We do know that he has seeing, hearing, and feeling, because we have found the eyes, the ears, and the feelers. He seems to have the taste of an epicure, always preferring his meats "high;" though he has no tongue, hence he must taste with the lining of his mouth and gullet. It appears he can smell too, else he could not always be 
able to find his loud-smelling food; yet he has no nose. Some people imagine that he carries his nose in his long feelers (Fig. 109). The eyes, as you have seen, are away in front, at the ends of the first pair of joints, or APPENDAGES (Fig. 116) - the eye-stalks. The eye is kidneyshaped; instead of having one window or pupil, as your eye has, through which the light enters, the whole front is divided into squares like old-fashioned window-panes (Fig. 125). Each square is really a separate eye, and

Fig. 125.

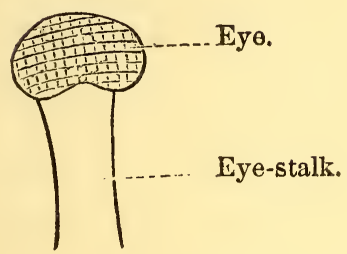

Coloring-matter.

Cone.

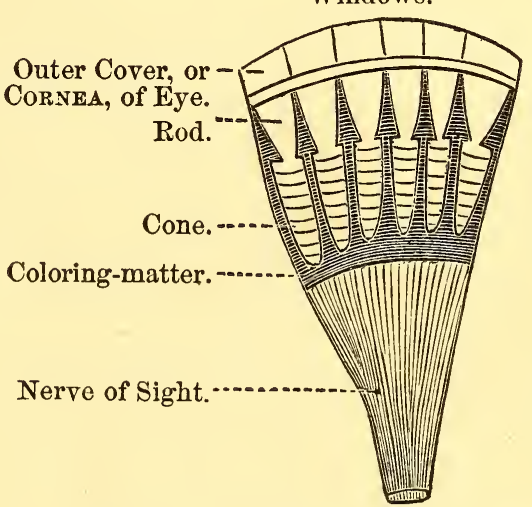

The Lobster's Eye, showivg how the Nerve is JOINEd to the WinDOWS IN FRONT BY THE RODS AND Cones.

this is what is called a compound Eye. The LOBSTER's eyesight must be very good, for, besides having all those eyes, the eye-stalks are jointed so that he can turn them in different directions. The nerve which goes to the eye 
is called the optic nerve, and it is connected with each square by pretty RoDs and cones, which look like those in your own eye (Fig. 126). The RoDs and cones are covered with coloring-matter, or PIGMENT, which turns red when it is boiled. The optic nerve is a NERVE of SENSATION, because it gives the lobster the sense of sight. Now, where are the LoBster's ears? Not in the foot, as the MussEL's, but in their proper place-the head. If

FIG. 127.

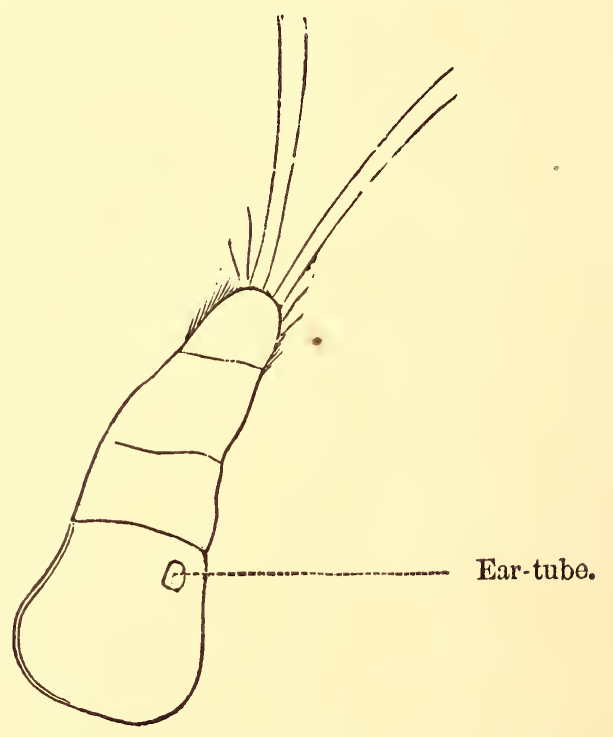

Little Feeler, or Antennule, showing Ear-Tube at its Base.

you look at the base of the little feelers on each side, you will find a little three-cornered slit covered with hairs (Fig. 127). This slit leads into a small sac filled with 
water, and one side of this sac is pushed inward to form a sort of fold, or pocket, in which a nerve that comes from the brain, or head GANGLIA, spreads itself all out (Fig. 128). The side of the pocket toward the water is

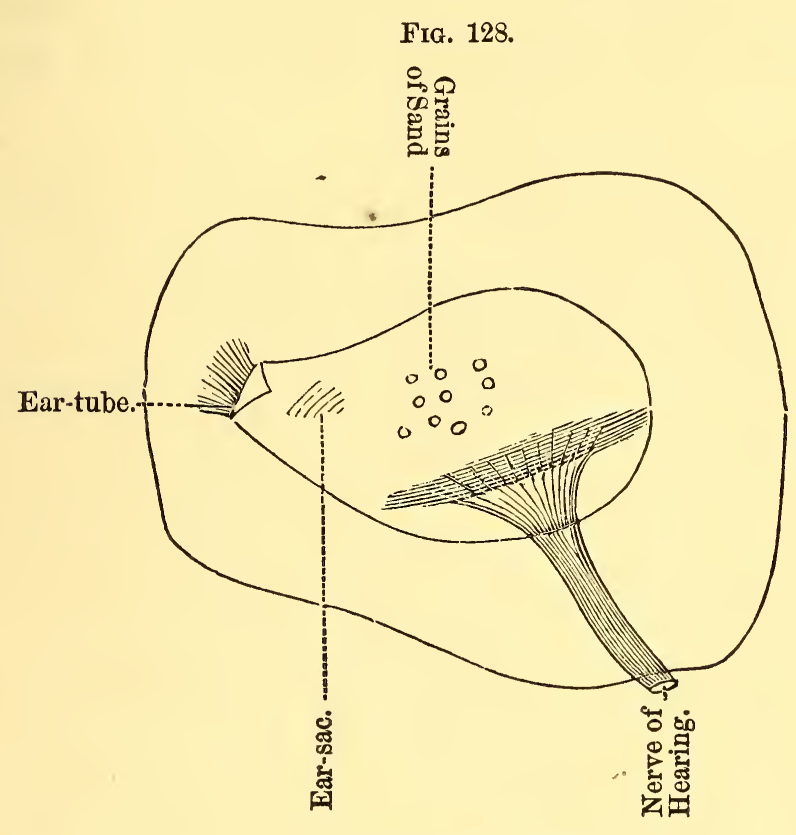

The Lobster's Ear.

covered with fine hairs, and these hairs touch against little bits of sand which get into the water through the outside slit (Figs. 128, 129). These particles of sand are like the tiny stones, or otoliths, you found in the Mussel's ear-sac, and they likewise help to increase the sound. The Lobster's ear is made on much the same plan as your own. The sac is really a fold of the 
LOBSTER's skin, which is pushed in as you might push in the crown of your soft hat, or as I used to make a pocket in my apron by pushing in a fold of the muslin and then pinning together the sides of the fold, leaving an opening at the top for my hand-just so Nature makes the ear-pocket and the other sacs of

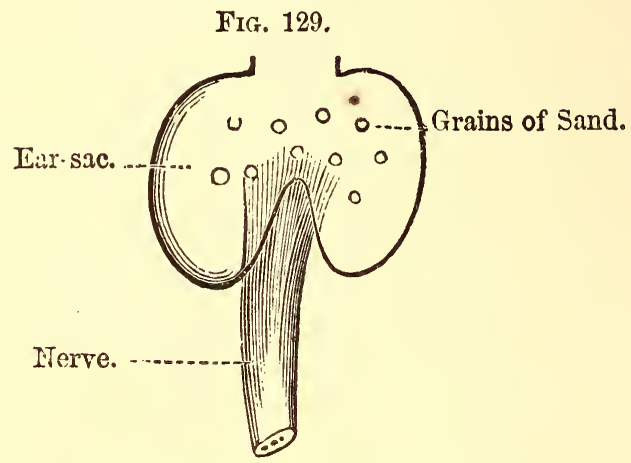

The Nerve pushing into the Pocket.

the body. At first the skin is all smooth on the surface; then she pokes a bit of it in wherever she wants a sac, and leaves little openings wherever they are needed. Now I dare say you are wishing to hear about the LOBSTER's "BAIRNS," or little ones. The LOBSTER's eggs, when they are first laid, are covered by a soft, sticky glue, which fastens them to the long hairs, that cover the paddles of the swimMerets under the ABDomen. The good mother Lobster doubles up her body so that the eggs are all folded inward, safe from harm while they are hatching. Hundreds of eggs are 
carried in this way, and when the LOBSTER is boiled they turn red, and form what is called the corcal, because they look like rows of tiny coral beads. This portable nursery is a very nice invention of the LOBSTER, and it saves the mother a deal of trouble. The kangaroos also have a kind of portable nursery for their little ones. The baby LOBSTERs differ greatly from their parents; their eyes are very large, and set in the head instead of being raised on eye-stalks. They have a great rounded headshield (CARAPACE) and a small body (Fig. 130). The

FIG. 130.

\section{Head-piece, or CARAPACE.}

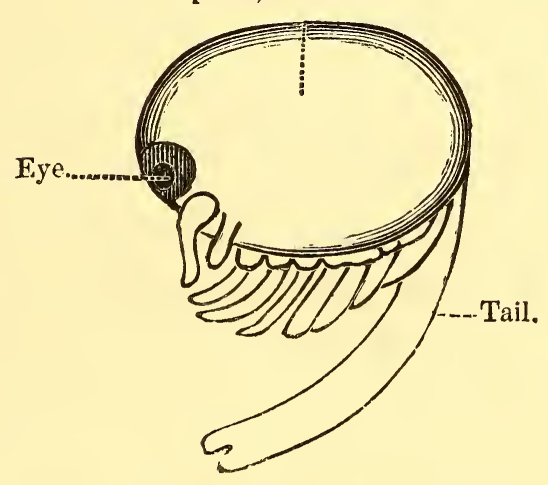

YOUNG LOBSTER.

limbs are not at all like the LOBSTER's; altogether he looks as if his eyes and head were running away with him. As soon as he is hatched from the egg, he begins to swim about and feed himself, and never goes back to the old nursery or has any thing more to do with the 
old folks at home. Of course, as he grows his shell gets too small, but, instead of putting on an addition as the Musseu does, he leaves the old house altogether and builds a new one. How he ever extricates himself from all the numerous extensions and divisions of his dwelling is indeed a mystery, and how he can possibly build a new house in so short a time as he does is another mystery. In three days after the LOBSTER moves out of the old house, he has been found settled in a bran-new one, one-third larger. He is about as swift a worker as the red and green snow-carpenters we found in the arctic and Alpine regions. When the LoBsTer's shell begins to pinch, it makes him feel very uncomfortable and bilious-like; at least he does not care to go into society, lest he should become unnecessarily exposed to the rude gaze of the unfeeling crowd. So he retires by himself to a quiet place, fastens his feet to some firm body, and moves himself about till he has broken the last tie that binds him to the old home; then the walis begin to crack between the shell of the head-the CARAPACE-and the shell of the body-the ABDOMEN. Now the LOBSTER pulls himself slowly backward till his eyes are fairly through the crack, then he gives one jump backward, and leaves the whole thing at a single bound. The old habitation, with every apartment complete, even to the very teeth in the old mill, remains 
fastened to its moorings by the shells of the six feet. Any one passing that way would never dream it was forsaken by its owner--the "mill-wheel gone to decay, Ben Bolt."

Now let us look after the houseless one. At first the shock of finding himself alone on the bare sand, with no roof over his head, is too much for his failing strength to bear, and he staggers about like one in delirium. His poor naked feet cannot support his weight, and his long, slender feelers are blown about in the wind like fine cobwebs; but he has plenty of pluck, and in a few moments he rouses himself to his condition. He does not regret his "leap in the dark," nor sit down on the sands and whine over his nakedness, but, like Mr. Dombey's sister, he " makes an effort," and soon feels himself growing larger and stronger. So he spreads out his paddles and fins, and jumps about till he finds a sheltered spot in the rocks, where he can safely settle down and wait for his big new house. You have probably thought of the likeness between the shell of the Lobster and that of the Musser. You know the MusSEL's shell is a hardened or CALCIFIED layer of his skin, or MANTLE. The LOBSTER's shell is formed in the same way, only he seems to have a quicker plan of hardening it, and the lining is different; it is so very red, at first sight you might think it blood; but it is the coloring- 
matter, or PIGMEnt. Two round balls are often found in the LOBSTER's stomach, and people call them " crab's eyes." These balls are made of lime, which it is said the LOBSTER has been storing up for his new shell, and that the Lrme finds its way to the outside skin and makes it hard in three or four days. Thus the lobster moves " out of the old house into the new" every year till he gets his growth; then he lives contentedly under the same roof till he dies, or till some one throws him into boiling water. I hope the members of the Society for the Prevention of Cruelty to Animals will not forget these cruel LOBSTER-POTS. 


\title{
CHAPTER VIII.
}

\author{
THE BUTTERFLY.
}

All about Johnny's Caterpillar-its Fine Sculpturing, Tailoring, Spinning, and Mechanical Genius.

One morning, when Johnny was a very little boy, I heard him crying in an unusually loud voice, away in the garden. I rushed out of the house to see what was the matter, and found him kneeling upon the ground, while the tears were running in streams from his eyes upon the mangled corpse of a caterpillar! It seems he had as usual filled his little wagon with caterpillars to take them a "morning ride," when this poor unfortunate one crawled out on the wheel, and was so crushed that, like Humpty Dumpty, "all the doctors in the land" could never make it stand again. I could not help feeling sorry for the child; neither could I help wondering what he saw in that hairy, skinny, squashy mass to love and cry about-I did not myself then know the many curious things it contained, else I might 
have told Johnny about them, and thus have comforted him for the loss of his strange playmate.

Most people, especially children, are afraid of caterpillars; but there is only one kind that is really dangerous to handle-the scarlet and black caterpillar, known as the "palmer-worm," which stings worse than a nettle. Thus, though caterpillars are not the most agreeable-looking, they are, generally speaking, the most harmless of pets, and there is nothing in Nature more interesting. If you had not been told, you could hardly imagine that these clumsy, crawling things would turn into graceful, gorgeous butterflies. You cannot see any likeness between them; but, as we study, we may find a likeness not only between the butterfly and caterpillar, but between the butterfly and another animal which looks still more unlike it. The caterpillar, as you know, is the butterfly's baby. Is it not odd that such a beautiful mother should have such an ugly child? But they say ugly babies make pretty grown-up people; and we know this is true of the butterfly's children, so they can afford to be ill-looking while they are young. The eggs, from which the little caterpillars are hatched, are very curious. They are so small, you might pass them by unseen, and no one would ever have known how pretty they are, had it not been for the microscope. Some of 
them are most beautifully formed and sculptured like antique vases and caskets (Figs. 131-134). One is shaped like the seed-box of the poppy, and others look like

FIG. 131.

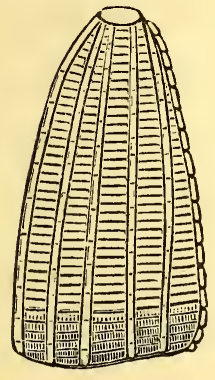

Fig. 133.

Fra. 132.

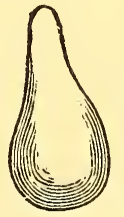

Fig. 134.

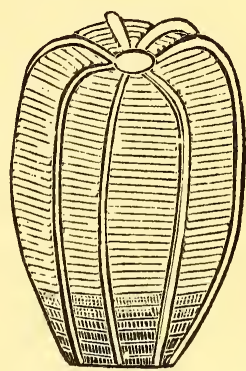

EgGs of Butterfly.

some of the lovely jewel-boxes in the "Green Vaults" at Dresden. So the sculptor might learn how to mould his clay into beautiful forms by taking the eggs of the butterfly for his models. Another curious thing about the eggs is, that the butterfly lays them upon the leaves which the caterpillar likes best. She does not eat the same food herself; then, how does she know what the caterpillar likes? She does not live to see him eat, for she usually dies before he is born. How does she know? Does she remember when she was a caterpillar? I am sure I cannot tell; at all events, the butterfly must be a good вотANIsT, as she can so readily tell one plant from another. When two plants, almost exactly alike to the eye, stand side by side, she will 
choose the leaves of the right one for her eggs. These eggs are covered with a kind of glue which fastens them to the leaf and keeps out the wet. You have perhaps seen the "fairy bracelets" which are sometimes placed round the twigs of bushes. Fairies may wear these bracelets on state occasions, but the fairies do not make them. They are the eggs of a moth laid in a circle round the twig and fastened together with glue. This bracelet is so strong that it will not break, though you break the twig. It is astonishing how much heat and cold these eggs will stand. They have been known to live at a temperature of $200^{\circ}$ Fahr., and cold at $22^{\circ}$ below zero will not kill them. The eggs that are laid in the spring hatch very soon, those that are laid in the fall do not hatch till spring. The last, like the germ of the bean, take a long, long wintry sleep, till the bright, warm, spring sun makes them open their eyes. As soon as the caterpillar bursts his shell, he begins to eat. He seizes upon the first thing that comes in his way, which happens to be his egg-shell, and this he devours most greedily. The whole end and aim of his life seems to be to eat. The very first day of his existence he eats up twice his own weight; so, of course, he must grow rapidly. At the end of one month he weighs a thousand times as much as he did at first, and, to make up this bulk, he has eaten forty thou- 
sand times his own weight of food! What a famous digestion he must have. No wonder gardeners dread to see caterpillars on their berry-bushes and fruit-trees. Soon he gets like the boy who ate so much pudding and plum-cake that he burst his buttons; but, as the caterpillar's clothes have no buttons, they split right down the back and drop off altogether. But he is a good tailor; and, before he gets fairly out of his old suit, he is into a new one, and, instead of leaving his old clothes for the rag-pickers, he turns about and eats them all up, and becomes more of a glutton than ever. He eats so much and gets so fat, that he has to have about six suits in one season, and, as he grows older and fatter, his vanity increases, and each new suit is more gayly trimmed than the one before! This casting off of his old clothes is called moulting. It has probably made you think of the way in which a LOBSTER gets out of his shell.

Now let us look at the external or outside appearance of the caterpillar. First, his shape. They are all roundish, some of them tapering at both ends, others more like a rolling-pin ; some short and fat, others long and graceful; some covered with hairs, others with tufts of hairs, like the "pon-pons" ladies wear in their hats. Their colors seem endless. Some are green, with white rings around their necks, others green, with red 
stripes ; and then, again, some are black, with light spots, or dark red, with brown spots. The very woolly-looking ones, and some of those with the highest colors, are the мотн-caterpillars. The difference between moths and butterflies we shall soon see. Some people think that all the quiet, brown creatures are мотнs, and all the gay, fancy-looking ones are butterflies. But this is a mistake. If you look carefully at a caterpillar, you will find probably that its body looks as if it were made up of rings, and, if you count these rings, you will usually find about thirteen (Fig. 135). The first ring is gener-

FIIG. 135.

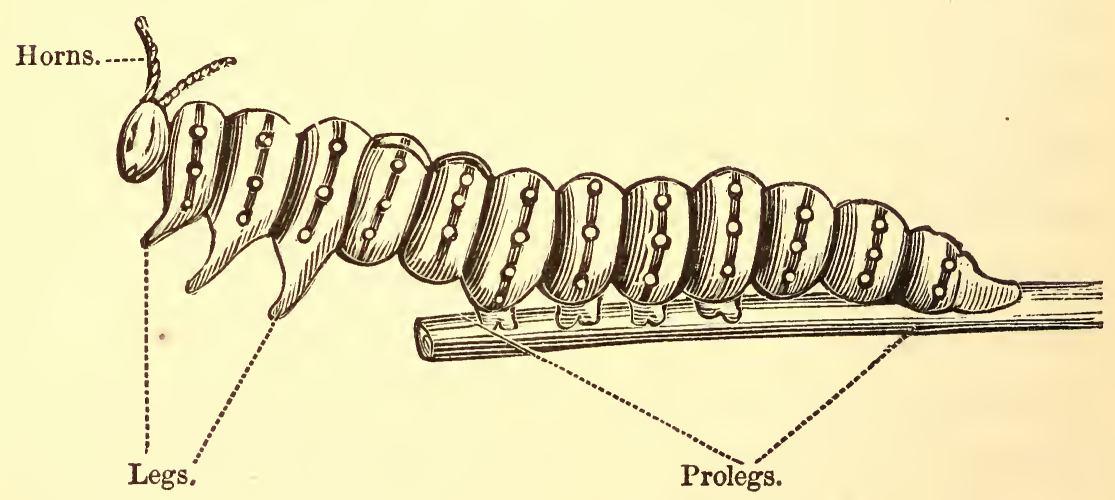

ally very small, and forms the head. The eyes are placed on the front part of the head, and look like two tiny black spots ; but the jaws and mandibles are strong and horny, and work from side to side instead of up and down. The first three rings behind the head are 
each furnished with a pair of legs (Figs. 135). These are the caterpillar's true legs, and they stand by him throughout his whole life, except when he is changing his suit; then the legs seem to skip over two rings, and we find the next four rings each giving off a pair of legs; then, again, the legs skip two rings; and now we come to the last ring, which gives off the last pair of legs. These five pairs are the caterpillar's PRoLEgs (Fig. 135), and he uses them to fasten himself while he is eating. The last sEGMENT, or ring, sometimes ends in a two-forked tail. The head, too, may have two hornylooking appendages (Fig. 135). When the caterpillar eats, he fastens himself by his PRoLEGs, and then guides the edge of the leaf between his real legs. Thus fixed, he stretches his head as far as possible, and begins to eat backward toward his legs, one row of the leaf after another, till he reaches the MIDRIB; then he fastens himself to another part of the leaf, and so on till it is all gone except the stalk. So much for what you see outside of the caterpillar! Now, I wonder what he has inside? From the amount that he eats, you might think he had no room inside for any thing but a stomach. But he is not as low-minded as he seems; his internal arrangements show that he has "great expectations," and that he is thoroughly preparing himself for a higher state of existence. His mouth opens into a 
gullet, and this gullet leads backward into a stomach (Fig. 136), not such a very large stomach either as one might suppose. This opens, again, into an intestine, which runs straight back, as the LOBsTER's. On each side of the stomach and instestines lies a mass of wavy threads (Fig. 136), which seem all tangled together; but they are all quite separate, and each one is a little duct, or tube, and the whole mass is the caterpillar's LIVEr. All these are called the DIGestrve ORgans, because they help to digest, or make ready, the food. Next, how does the caterpillar breathe? Where are his ORGANS OF RESPIRATION? You cannot find any gILLS, as in the Mussel and LoBster. The caterpillar could not use GILLs if he had them, for he does not live in the water. On each side of his body you will find a number of openings which look like so many button-holes (Figs. 136, 137). Each one opens into a ringed tube which runs inward. These tubes are crossed by one long tube which runs lengthwise on each side of the body. Then these tubes divide and subdivide, and spread themselves through the whole body, so that, taking up the smallest piece of the caterpillar, you will find some of these tiny tubes. The air does not enter the body through the mouth, but through these button-holes, or sPIRACLEs, in the sides of the caterpillar, and then into the tubes, and so throughout the whole 


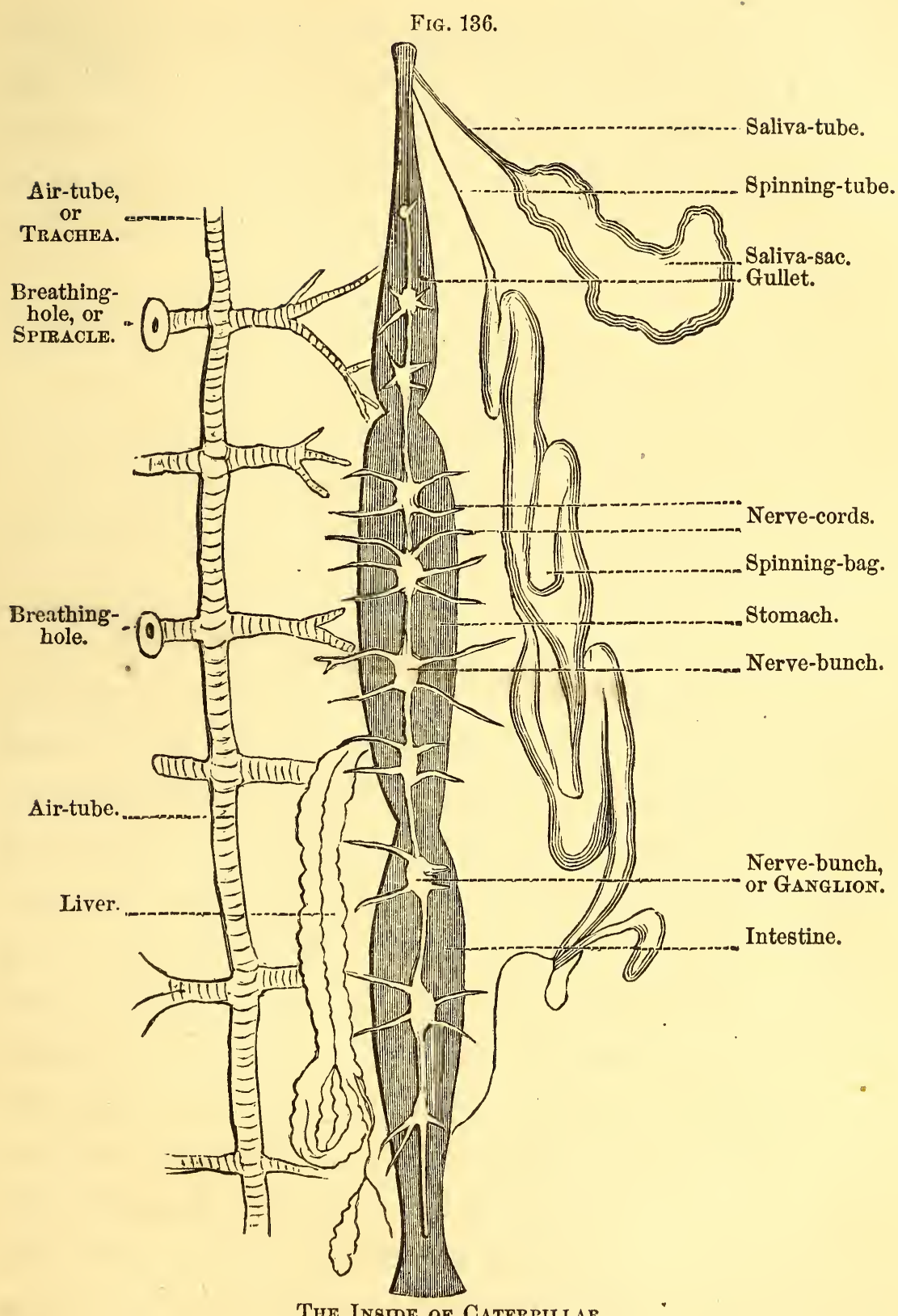

The Insme of Caterpillar. 
body. You know that the air contains dust which would soon fill up the air-tubes, and hence, at the entrance of each air-tube, or SPIRACLE, is a hair-like sieve which strains the air and keeps back the dust (Fig. 137).

Fig. 137.

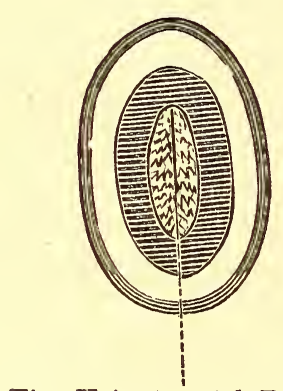

Fine Hairs to catch Dust.

Breathing-Hole, or Spiracle.

In like manner, the air which you breathe is filtered before it enters your lungs, by the hairs which line the NASAL or nose passage. So, you ought always to breathe through your nose instead of through your mouth. Thus you see what great care Nature or Nature's God has taken to protect the life of all living things, from the littlest plant to the largest man. If we could be as careful of ourselves and of each other! The caterpillar's body is so 'soft, and then he has such a habit of rolling himself into a ball, that the air-tubes might collapse, and the caterpillar would die for want of breath. But the tubes are kept open by a 
twisted or SPIRAL thread, which runs all through them like the spiral thread which keeps the air-vessels of the bean-stalk open, thus protecting the life of the vine. Indeed, they look very much like the SPIRAL VESSELS of plants (Fig. 138). This machinery for breathing, or

FIr. 138

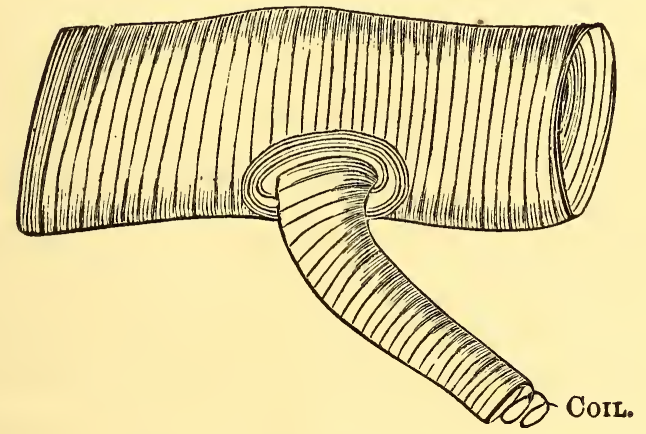

Air-Tube, with one of its Branches.

RESPIRATION, is entirely different from that of the musSEL or LOBSTER. There is no special place in the body where all the blood comes to get air. "Instead of the blood coming to the air, the air goes to the blood" through the little tubes that we find spreading themselves through the whole body (Fig. 138). The tubes are called TRACHEE, or wind-pipes-trachus means rough, and these rings make the air-tubes quite rough. When the air is to be expelled, the creature brings the walls of his body together and forces the air out.

The circulation of the caterpillar's blood is brought 
about by the sinking and swelling of a vessel which runs along the upper or Dorsal side of the body. The blood is a colorless, watery fluid, and you can see it flowing into the dorsal vessel through little mouths in the sides. Each mouth has a little valve, which prevents the blood from going back again. You may sèe this vessel beating along the caterpillar's back, and the blood is sent from the tail to the head, instead, as one would suppose, from the head to the tail; and this blood goes back again by vessels on the under or VENTRAL side.

The caterpillar does not look or act like a nervous individual ; nevertheless, he has a great many nerves. You can see the chain of nerve-bunches, or GANGLIA, running close to the DIGESTIVE ORGANS, connected by cords, like the LoBsteR's (Fig. 136). The bunches above the gullet are the HEAD GANGLIA, or the Brain, and they give off nerves to the eyes and other parts of the head. The caterpillar's brain is not of so much importance to it, for he has large bunches of nerve-matter, GANGLIA, in other parts of his body. Besides, he does not breathe through his mouth. If his head is cut off, the part he misses most is the jaws ; and I suppose, if a new pair would grow, he could get on about as well without a head as with one. The most merciful way to kill a caterpillar is not to cut off his head, but to stop up his breathing-holes, and this can be done by smear- 
ing the body with a little oil. We know, from the bending and stretching of the caterpillar's body, that he must have good muscles. Caterpillars can throw themselves straight out from the limb of a tree, as you throw out your arms from your body, and keep in that position without moving for an hour at a time. This shows how very strong the muscles must be, and they are also very numerous. Some caterpillars have over four thousand separate muscles! They are far more curious than the LOBSTER's, because, besides the blood-vessels and nerves which pass through them, they are all tunneled by the ringed tubes, or TRACHEx. There are two other large parts, or organs, in the caterpillar, which, if you did not know better, you might take for the stomach and Intestine. They lie on either side of the DIGESTIVE ORGANS, and look like a large Intestine, a good deal twisted, and tapering to a fine thread at each end (Fig. 136). This tube is filled with a soft, toughish glue, or gum, which seems to come from the food through one of the fine threads, the one that opens into the Digestive canal. The other thread opens into the mouth by a tiny tube (Fig. 136), called a spinneret, or little spinner. Now, what is it that our caterpillar has to spin? Why should he be a spinner as well as a tailor? You have often seen the caterpillar swinging by a thread. He can let him- 
self down from high branches when he thinks there is danger near, and hide himself in the grass; then he goes back to his perch by the same thread, when the danger is past. Possibly you thought this a stray cobweb that the caterpillar had appropriated to himself. Not at all; it is a cable of his own manufacture. Let us see how he makes it. Some of the gum that we found in the bags passes down through the fine tubes, getting smaller and smaller, till it reaches the little spinning-machine (SPINNERET) where the two fine threads are joined into one ready for use whenever needed. Thus the caterpillar furnishes the raw material and spins his own yarn, for which he has other uses, as we shall soon see. The yarn which the silk-worm spins, you know, is very valuable, and its value depends a good deal upon the way in which these two threads are made into one. There is still one other organ in the caterpillar. On each side, in front of the spinning-bag, is another smaller bag, opening into the mouth by a tube. These bags contain the caterpillar's spittle, or SALrva, which he never uses except on proper occasions, consequently caterpillars are not obliged to have spittoons in their drawing-rooms. Thus, you see, the crawling caterpillar is really a very wonderful creature. He seems to be higher up in the scale than either the MUsseL or LOBSTER, because his breathing-apparatus is more like 
that of the higher animals. We now come to a time in the life of our friend in which he actually refuses food! Surely, some great change is coming over him. Perhaps he is going to die. Let us watch him. He leaves all the beautiful green tables, spread with his favorite dainties, and seeks a quiet place where, unobserved, he unfastens his woolly coat and throws it offjaws, legs, and even the whole lining of his stomach.

Fig. 139.

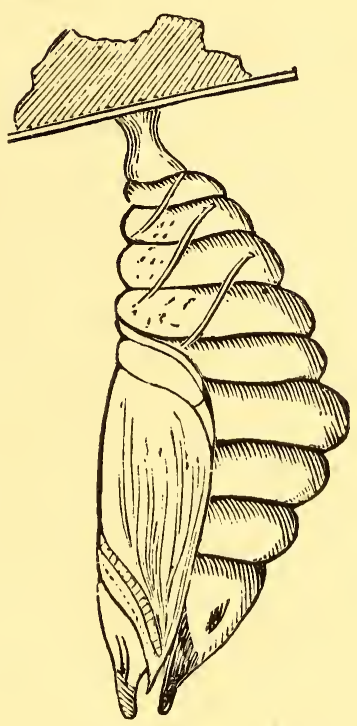

Tine Pupa, or Chrysalis, manging by the Tarl.

Thus he is left naked, jawless, armless, legless-nothing in the world to call his own; just like our LoBster, only a great deal worse. The only things by which he 
can help himself at all are, his little sPINNERET in front, and the two very tiny hooks at the end of the tail. By a strange "sleight-of-hand," that is, without any hands at all, he fastens himself to some object by these two little forks, and begins to work away with his little SPINNING-JENNY, to make a covering for himself. In a very short time you see him hanging from a leaf in a sort of silken hammock, like a sailor asleep. There are two ways in which he slings his hammock: in one. way he attaches himself by the tip of his tail, his head hanging down (Fig. 139); in the other he fastens his tail upon the leaf, and keeps his head from swinging about by a band, or girdle, which he throws around the upper part of his body (Fig. 140). The caterpillar,

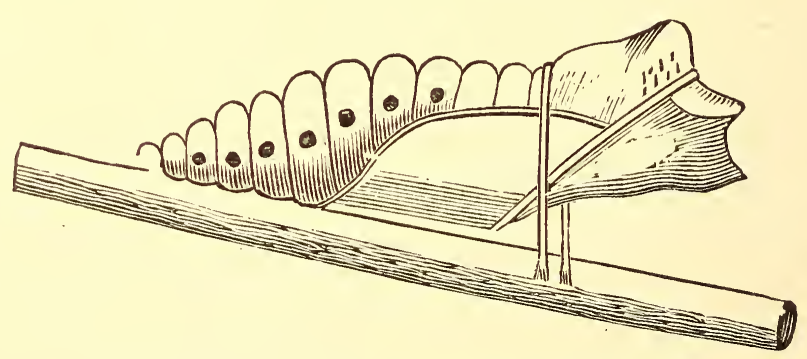

Chrysalis, with Head fastened by a Suing.

before he enters the hammock, is called a LARvA, which means MAsk ; of course, when the butterfly is crawling about as a worm, he is in disguise. This is the butter- 
fly's masquerade. After he has thrown off the Mask, he is called a PUPA, because he wraps himself up in his silken web as a baby is wrapped in its bandages. It makes one think of a little Indian papoose. Then, again, he is called a cHrysalis, for sometimes his hammock is spotted with gold. Only two of the butterfly farnilies - the VANESSAS and the FRITELLARIES - the " big wigs," I suppose, attempt this kind of ornament. The hammocks are usually quite plain and unpretending. Some of them are so thin, you can see the pupa through the meshes. It looks white, and covered with a kind of oil, and you can pick out almost all the parts of the butterfly. The feelers (ANTEnna) are folded down by the legs ; and along the centre of the body, between the legs, you can see the long tongue lying in a straight line. On the sides you can see the air-slits, or sPIRACLEs, and the wings show all their veins. If the weather is warm and bright, the pupa comes out of his shell, or hammock, in seven or eight days. In the spring it takes him two or three weeks to turn himself into a butterfly. If he goes into the papoose state in the fall, he sleeps all winter in his cradle, and comes out a butterfly in the spring. Indeed, if these sleeping caterpillars are kept in a cool place, they will sleep on for two or three years; but, if one were suddenly taken into a hot-house in winter, the heat would arouse it, and the butterfly 
would come out in a few days. You can always find plenty of babies, or PUP es, and you can gather them and watch them for yourselves. Sometimes, when you are watching for the butterfly to burst through his silken shell, you may see, instead, a whole swarm of black, impish-looking flies. They are called the Ichneumonflies, and their chief diet is caterpillar-flesh. Every year they destroy thousands, and this is the way they do it: the mother-fly (Ichneumon) makes nests by sticking little holes all along the back of the caterpillar, and this only causes the caterpillar to squirm a little. In these nests she lays her eggs, which hatch into little white grubs, or worms. They feed on all the fat of the caterpillar, but take good care not to touch any of his organs, because, if the caterpillar dies, they would have to die too. But, as soon as the caterpillar stops eating and goes to sleep in his hammock, and so cannot provide any more food for the grubs, they fall to and devour every morsel of him. When they have finished their last meal, they take a nap themselves, and, while they are sleeping, their outer-coat gets hard and bursts; and, just about the time that the poor caterpillar would turn into the butterfly, out come the troop of black flies.

Now for the caterpillar's transformation. The PUPA or cirrysalis skin turns dark, gets dry and brittle, and 
you can see all the parts of the butterfly shining through it. Finally it splits in several places, and the butterfly crawls ont and begins to dry off the oil in the sun. At first the wings look small and limp, but as soon as the butterfly breathes they swell out and get larger, as the air-tubes (TRACHEx) in the wings become filled with air. In about an hour the new butterfly is all nice and dry, beautifully painted and polished, and away it goes skimming through the air in search of sweet syrup to sip from the cup of some flower. Now our friend is called an Imago, or image. In the first place he wore a mask, hence his name LARVA ; then he went to sleep in his homespun blankets like a baby in its cradle, so he was called a PUPA. Now he has come forth an IMAge, a perfect image of the butterfly, so now he is an IMAGo. Almost all INSECTs, the class of animals to which our butterfly belongs, pass through these three stages of life. There is one thing to remember about this IMAgo, it never grows after it is born, so none of the little flies and moths that you see ever get to be big ones. The first things you are likely to notice about the butterfly are the wings. They are very showy and most beautiful too, but we will not begin to study them just yet. First of all you can see that there are three distinct parts to the butterfly's body-a HEAD, a breast, or тHоrax, and a body, or ABDomen. The thorax and ABDo- 
MEN are again divided, as the LOBSTER's, into body-pieces - somites. All insects have three pieces, or somites, in the breast, or THoRAx, but all do not have the same number of pieces (sommes) in the ABDomen. Some have eleven, others not so many. At the top of the butterfly's head you will see two great COMPOUND EYES (Figs. 141, 142), all divided into six-sided squares; each

FIG. 141.

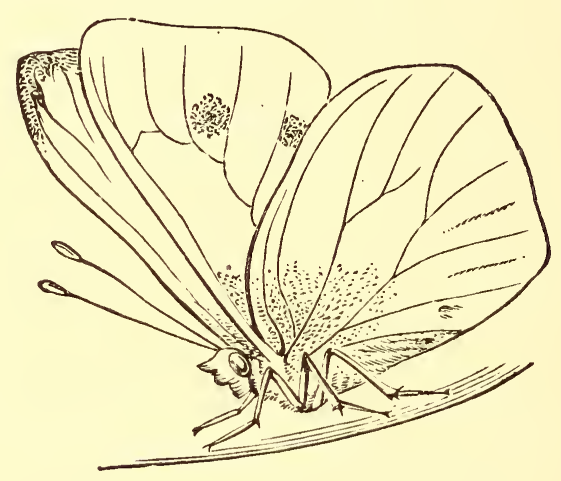

square, you know, is a separate eye, and some butterflies have more than thirty thousand in both eyes! These COMPOUND EYES are not set on stalks, as the LOBSTER's. Next we come to the butterfly's curious mouth. Two horny scales at the sides of the mouth are all that are left of the LOBSTER's large MANDIBLEs or the caterpillar's jaws. Behind the mouth you will see something like the LOBSTER's lip (LABRUM), a small scale with two long palps (Fig. 142). We find the mouth itself all coiled up un- 
der the head and hidden by the palps (Fig. 141). When it is straightened out it looks like a long, slender tube, but it is really made of two pieces, or half-tubes, one

FIG. 142.

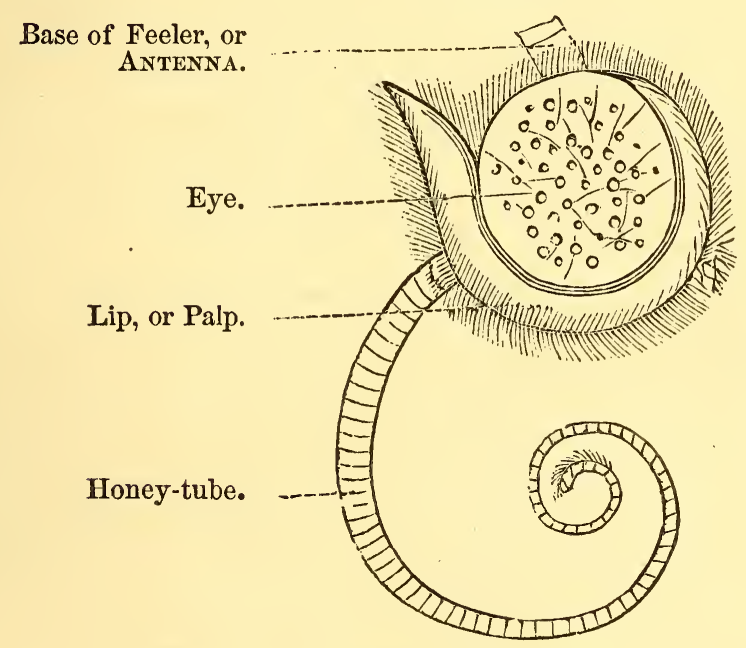

Head of Butterfly.

each side. These are fastened together in the middle by means of very fine hairs along the edges, as you might fasten together two brushes. These two long, fine half-tubes take the place of the LOBSTER's little jaws (MAXILLA), and they are made in this way because the butterfly has to suck honey out of the deep tubes of the flowers (Fig. 142), so he does not need the strong pincers, scissors, and jaws, of the LOBster. It is also a good plan to have his bill in two pieces instead of one, because it is so much easier to keep it clean. You know 
honey is rather sticky stuff. In the butterfly's sucker, or mouth, you see one large opening and several smaller ones (Fig. 143). The large one is probably for the pas-

FIG. 143.

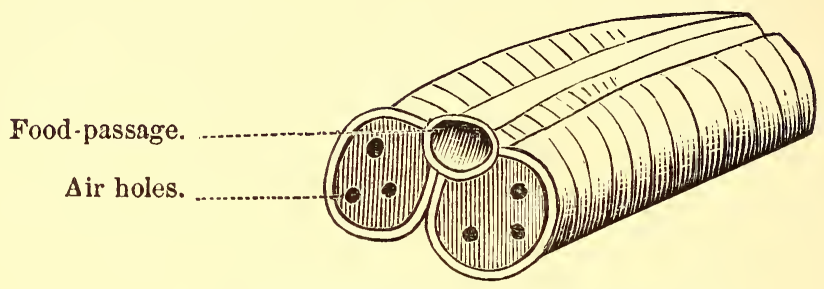

a Cross-Cut or Section of Tube.

sage of the food, and the smaller ones for the air with which he sucks the food.' On the outside, toward the end of the sucker, you see a number of little buds (Fig. 144). These are probably the butterfly's tongues, with

FIG. 144.

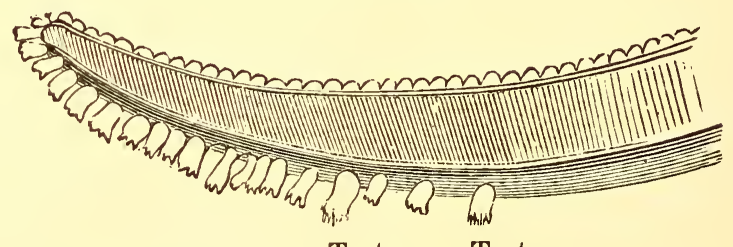

Taster. Taster.

End of Butterfly's Bill, showing the Tasters.

which he tastes the honey before eating it. This mouth is a very perfect piece of machinery, and yet so small, that the whole thing is not thicker than a horse-hair. To human hand could make such a piece of workman- 
ship. The butterfly has two antenne, or feelers (Fig. 141), placed in sockets, one at each side of the head (Figs. 142, 145). They are long and jointed, and have

FIG. 145.

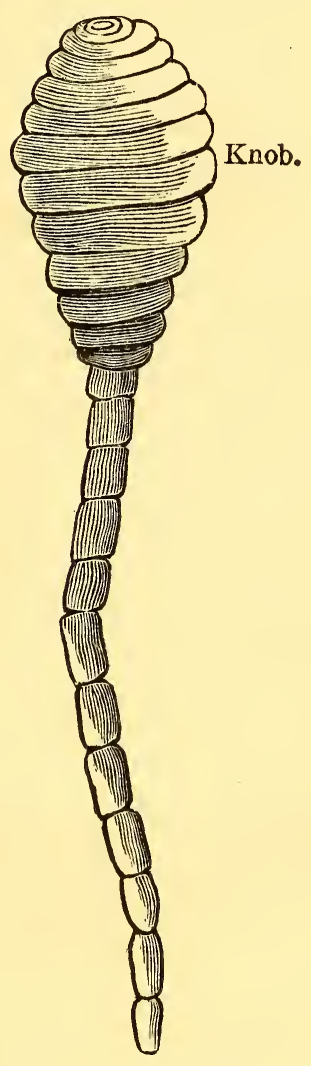

Butterfly's Feeler, or Antenna.

club-shaped ends. The shape of the feelers (ANTENN $\approx$ ) is the great difference between BUtTERFLIEs and мотнs. The feelers, or ANTENN 2 , of the moths have pointed 
ends, while the butterflies' are always knobbed. It is with the ANTENNe that the butterfly feels and smells, and they answer to the LoBster's long feelers. On each bottom-piece, or STERNA, of the three breast-pieces-the THORACIC SOMITES-you will find a pair of legs (Fig. 141). These three pairs of legs correspond to the caterpillar's true legs. Sometimes the first pair are very short, too short to walk upon. Perhaps the butterfly uses them as hands to clean his bill. The wings usually grow from the back or TERGAL parts of the second and third тноRACIC somites (Fig. 141), and they correspond to the side-piece-the PLEURON, or GILL-COVER, of the LOBSTER. They are of many shapes, sizes, and colors, and sometimes there are two pairs. All boys and girls have chased butterflies, and all know that their wings are mealy. This meal comes off on the fingers and colors them, just as the PoLLEN of flowers comes off and colors the nose. If you put the wing under the microscope, you will change your mind, and say that it is covered with scales instead of meal. Each speck of this fine powder is a brilliant-colored, feathery scale, and, if you place the root of the wing toward the light, you can see how the scales are arranged in rows, overlapping each other like the scales of a fish; hence the butterfly is said to be one of the scaly-winged family-LePIDOPTERA. Lepis means a scale, and ptera wings, so this long, hard name 
is very simple-scaly wings. The colors and designs of these scales surpass any thing I have ever seen. All the fine painting, tapestry, and mosaics, made by men

Frg. 148.

FiG. 146.

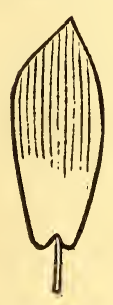

FIG. 147.
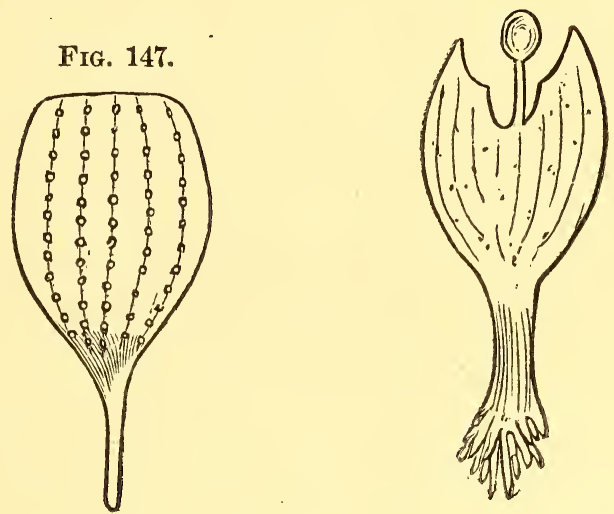

FIG. 149.

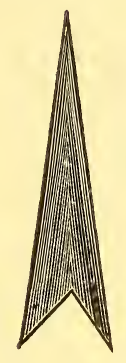

FIG. 150.

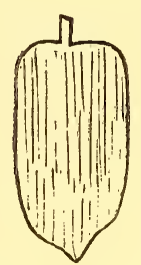

Scales of Butterflies' Wings.

look best when seen from a distance, and if you look on the wrong side you see nothing but rough canvas, straggling threads, and bits of stone. But the butterfly's painting, tapestry, and mosaics, are all the more lovely 
the closer you see them, and the wrong side is often as beautiful as the right. Just that dust of meal the butterfly leaves on your fingers contains colors as rich as the rainbow, and jewels as brilliant as the pearl, topaz, and sapphire, all shining together. If you examine them separately, you will find many different shapes; most of them resemble leaves, and the little stem that fastens them to the wing looks like the foot-stalk, or PETIOLE, of the leaf (Figs. 146-150). One is formed just like a battledore. Each tiny scale has three layers; those

FIG. 151.

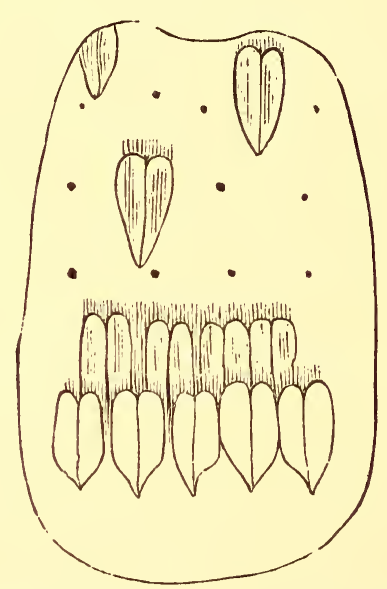

Butterfly's Wing, showing how the Scales are fastened, and the Scars of the Fastenings.

outside are highly colored and decorated, while the inside one is plain and forms a foundation for the ornamental work. The wing itself where the scales are 
all off shows all its veins or ribs, and is covered by a thin membrane all marked with little spots, where the scales were fastened (Fig. 151). In some butterflies the under sides of the wings look exactly like dried leaves, while the upper sides are gorgeously colored. When such a butterfly is chased, he drops down and folds back his wings, and so his pursuer misses him, thinking him a withered leaf. The internal parts of the butterfly are very much like those of the caterpillar. As he has no more use for the spinning-bags, they all dry up, leaving nothing but little fine threads in their places. The butterfly's life is very short; it lives only long enough to lay its eggs, and it never sees its dear little caterpillar-babies. But it appears to make the best of every thing, and looks so very bright and happy that some people envy its care-free life. A great many poets have written songs about it; there is one very pretty one:

\section{"I'd be a butterfly,}

Born in a bower."

But I have no doubt you would rather be boys and girls than butterflies. We have now traced the resemblance between the caterpillar and the butterfly. By taking off the caterpillar's mask, the great woolly skin, and looking carefully at his body, we found nearly all the parts of the future IMAGo; and we have found, too, 
that the beautiful butterfly is very much like the fierce, odd-looking LoBster. Let us first notice the general shape of their bodies; both are long, rounded, and tapering at each end, with joints, or APPENDAGES, hanging down each side. The body of each is divided into three parts-the HEAD, THORAX, and ABDOMEN; and these are made up of different pieces called somrtes. The somites have a back or tergal portion, a side, or PLEURon, and a lower or sternal portion. The butterfly's wing corresponds to the PLEURon, or side-piece, of the somite which covers the GILLs. There is also a great likeness between the APPENDAGES of the two animals. Both have compound eyes at the front of the head; the main difference between the eyes is, that the LOBSTER's are placed on movable stalks, while the butterfly's are sEssiLe, that is, they are set in his head without stalks. The LoBster has one more pair of feelers than the butterfly, and the butterfly's feelers answer to the second pair, or the Antennules, of the Lobster. There looks to be no resemblance between the mouth of the LOBSTER and that of the butterfly, yet there is a close likeness. The scale with two long palps takes the place of the LoBSTER's LABRum. The horny scales at the sides are the LOBSTER's jaws, or MANDIBLEs, made butterfly-fashion; and the two strong Maxille, or little jaws, of the lobster are worked over into the two long, fine half-tubes. 
of the butterfly's PROBOSCIs, because the butterfly is a honey-sucker and not a "beef-eater." Now come the three pairs of feet on the breast, or THorax; they are not shaped as the lobster's, for they are not used in the same way. The butterfly has no prey to catch and cut up, and hence he needs no claws and no scissors. As he does not swim, he needs no swIMMERETs, or tail-fin. Nature never gives an animal what is of no use to him. The way in which the baby-butterfly casts off his old clothes is very much like the way in which the young lobster flits from his old house into his new one. So much for the outward resemblance; let us see if we can find any likeness between the inside arrangements. There is the DIGESTIVE CANAL in each, consisting of the gullet, stomach, and intestine, with the liver on each side, running in a straight line from the head to the tail. The nervous system is made on the same plan, and takes the same direction in both. Each has a chain of nervebunches, or GANGLIA, on the VENTRAL or lower side of the body, and each has a heart, or a Dorsal vessel, which takes the place of a heart, on the upper or DoRsal side of the body. The muscles of the LOBSTER are attached to the inside of his shell, so the muscles of the butterfly are fixed to the walls of his somites. So we might very well call the butterfly a land-lobster, and the lobster a water-butterfly, for there is just enough change in 
structure to make each one comfortable in his own home.

And now, before saying good-by, let us sum up what we have done, and talk a little of what we may yet do. We have studied pretty carefully what mercantile people might call "samples" of those animals that have no backbone-the INVERTEBrates. (A vertebra is one of the pieces which make the backbone.) But, in order to learn about animals themselves, we had first to learn something about the plants upon which animals live. So we talked of a "sample," or typical Fungus, the rEAs'; a GREEN PLANT, the PROTOCOCCUS; and a FLOWERING PLANT, the BEAN. All plants belong under these three heads: FUNGI, GREEN PLANTS, FLOWERING PLANTS.

The animals that have no backbone are classed under five heads: PRotozoA, CELENTERATA, ANNULOIDA, ANNULOSA, MOLLUSCA.

Protozon comes from two words, which mean first and animal. All the first or simplest forms of animal life are placed under this division of the INVERTEBRAtes. The AMœвA is the sample of PRoTozoA that we have studied.

Cerlenterata comes from two words, which mean hollow and bowel. The animals whose stomach and the whole inside, hollow, or cavity of the body, are both in 
one, belong under this second head. The HYDRA is the sample of CGelenterata that we have studied.

Annuloida means ring-like. The animals that are classed under this head have usually been placed with the PROTOZOA, CELLENTERATA, and ANNULOSA (the animals whose bodies are made up of rings). Most of the annuloida live in the sea or the intestines of other animals, so but few of you could get specimens for examination; and it is hard to study an animal from pictures alone. The starfish and tape-worm are two of the more common samples of the annuloida. The starfish, which is not a fish at all, used to belong to the radiata, the old name for the second division (CCLLENTERAta) and the tape-worm was classed with the annulosa. But the starfish you can see only on the sea or in an aquarium, and the tape-worm you will hardly find outside a medical museum; so we pass these by for the present, to learn about the common animals-those that you can see almost every day, no matter how far from the sea-shore you may live.

Annulosa is the name given to those animals whose bodies are made up of rings. Annulus means ring. We have studied two samples of the ANNuLosa ; first, a CRAYFISH, or LOBSTER, which is also called a CRUSTACEAN, because it is covered by a crust, or shell; but it should not be called a fish, because all fish have backbones. 
The second ANNuLosa, or ringed animal, that we studied is the butterfly, which is called an InsEct. The word insect means I cut into. I suppose the animals are thus named, because their bodies look as though they were cut into three parts.

Mollusca comes from a word which means soft. The animals placed under this division of the INvERTEBRATES have soft bodies like the Mussel, the sample of Mollusca that we have studied.

So remember that all animals without a backbone are PRo'TOzon, or first animals ; CCELENTERATA, or hollowtube animals; ANNULOIDA, or ring-like animals; ANNULOSA, or ring animals ; MOLLUSCA, or soft animals.

And now all I can say of the future is that, if you are pleased and interested in these studies, we may have some talks about the vertebrates, or the animals with a backbone, such as fish and birds, apes and boys. Perhaps we may be able to prove that biology is not too big a subject for boys and girls.

THE END. 


\section{International Scientific Series.}

D. Appleton \& Co. have the pleasure of announcing that they have made arrangements for publishing, and have recently commenced the issue of, a SisRIES OF POPULAR MoNOGRAPHS, or small works, under the above title, which will embody the results of recent inquiry in the most interesting departments of advancing science.

The character and scope of this series will be best indicated by a reference to the names and subjects included in the subjoined list, from which it will be seen that the coöperation of the most distinguished professors in England, Germany, France, and the United States, has been secured, and negotiations are pending for contributions from other eminent scientific writers.

The works will be issued in New York, London, Paris, Leipsic, Milan, and St. Petersburg.

The International Scientific Series is entirely an American project, and was originated and organized by Dr. E. L. Youmans, who spent the greater part of a year in Europe, arranging with authors and publishers. The forthcoming volumes are as follows :

Prof. Lommel (University of Erlangen), Optics. (In press.)

Rev. M. J. Berkeley, M. A., F. L. S., and M. Cooke, M. A., LL. D., Fungi; their Nature, Influences, and Uses. (In press.)

Prof. W. Kingdon Clifford, M. A., The First Principles of the Exact Sciences explained to the non-mathematical.

Prof. T. H. Huxley, LL. D., F. R. S., Bodily Motion and Consciousness.

Dr. W. B. Carpenter, LL. D., F. R. S., The Physical Geography of the Sea.

Prof. William Odlong, F. K. S., The Old Chemistry viewed from the Nerw Standpoint.

W. LAuder Lindsay, M. D., F. R. S. E., Mind in the Lower Animals.

Sir JонN LuвBоск, Bart., F. R. S., The Antiquity of Man.

Prof. W. T. Thiselton Dyer, B. A., B. Sc., Form and Habit in Flowering Plants.

Mr. J. N. Lockyer, F. R. S., Spectrum Analysis.

Prof. Michael Foster, M. D., Protoplasm and the Cell Theory.

Prof. W. Stanley Jevons, Money: and the Mechanism of Exchange.

H. Charlton Bastian, M. D., F. R. S., The Brain as an Organ of Mind.

Prof. A. C. Ramsay, LL. D., F. R. S., Earth Sculpture: Hills, Valleys, Mountains, Plains, Rivers, Lakes: how they were produced, and how they have been destroyed.

Prof. RUdOLPH VirCHOW (Berlin University), Morbid Physiological Action.

Prof. Claude Bernard, Physical and Metaphysical Phenomena of Life.

Prof. H. Sainte-Claire Deville, $A n$ Introduction to General Chemistry.

Prof. Wurtz, Atoms and the Atomic Theory.

Prof. De Quatrefages, The Negro Races.

Prof. Lacaze-Duthiers, Zoology since Cuvier.

Prof. Berthelot, Chemical Synthesis.

Prof. J. Rosenthal, General Physiology of Muscles and Nerves.

Prof. James D. Dana, M. A., LL. D., On Cephalization; or, Head-Characters in the Gradation and Progress of Life.

Prof. S. W. Johnson, M. A., On the Nutrition of Plants.

Prof. Austin Flint, Jr., M. D., The Nervous System and its Relation to the Bodily Functions.

Prof. W. D. Whitney, Modern Linguistic Science.

Prof. C. A. Young, Ph. D. (of Dartmouth College), The Sun.

Prof. Bernstein (University of Halle), Physiology of the Senses.

Prof. Ferdinand Cohn (Breslau University), Thallophytes (Algae, Lichens, Fungi).

Prof. Hermann (University of Zurich), Respiration.

Prof. Leuckart (University of Leipsic), Outlines of A nimal Organization.

Prof. Liebreich (University of Berlin), Outlines of Toxicology.

Prof. KUNDT (University of Strasburg), On Sound.

Prof. REES (University of Erlangen), On Parasitic Plants.

Prof. Steinthal (University of Berlin), Outlines of the Science of Language.

E. Alglave (Professor of Constitutional and Administrative Law at Douai, and of Political Economy at Lille), The Primitive Elements of Political Constitutions.

P. Lorain (Professor of Medicine, Paris), Modern Epidemics.

Prof. SchützEnBERGER (Director of the Chemical Laboratory at the Sorbonne), On Fermentations.

Mons. Debray, Precious Metals. 


\title{
INTERNATIONAL SCIENTIFIC SERIES.
}

\author{
NOW READY.
}

No. 1. FORMS OF WATER, in Clouds, Rain, Rivers, Ice, and Glaciers. By Prof. John Tyndall, LL. D., F. R. S. I vol. Cloth. Price, \$r.5o.

No. 2. PHYSICS AND POLITICS; or, Thoughts on the Application of the Principles of "Natural Selection" and "Inheritance" to Political Society. By Walter Bagehot, Esq., author of "The English Constitution." I vol. Cloth. Price, $\$$ I. 50.

No. 3. FOODS. By Edward Smith, M. D., LL. B., F. R. S. I vol. Cloth Price, $\$ 1.75$.

No. 4. IMIND AND BODY. The Theories of their Relation. By Alex. BAIN, LL. D., Professor of Logic in the University of Aberdeen. I vol., I2mo. Cloth. Price, \$r.50.

No. 5. The STUdY OF SOCIOLOGY. By Herbert Spencer. Price, $\$ 1.50$.

No. 6. THE NEW CHEIIISTR. By Prof, Josiah P. Cooke, Jr., of Harvard University. I vol., I 2 mo. Cloth. Price, $\$ 2.00$.

No. \%. THE CONSERVATION OF ENERGY. By Prof. Balfour Stewart, LL. D., F. R.S. I vol., I2mo. Cloth. Price, \$r.50.

No. 8. ANIMAL LOCOMIOTION; or, Walking, Swimming, and Flying, with a Dissertation on Aëronautics. By J. Bell Pettigrew, M. D., F. R. S., F. R. S. E., F. R. C.P.E. I vol., I2mo. Fully illustrated. Price, $\$ 1.75$.

No. 9. RESPONSIBILITY IN IMENTAL DISEASE. By HENRY Maudsley, M. D. I vol., I2mo. Cloth. Price, \$r.50.

No. 10. THE SCIENCE OF LAW. By Prof. Sheldon Amos. I vol., I2mo. Cloth. Price, \$r.75.

No. 11. ANIMAL MECHANISIM. A Treatise on Terrestrial and Aërial Locomotion. By E. J. Marey. With II7 Illustrations. Price, \$r.75.

No. 12. THE HISTORY OF THE CONFLICT BETWEEN RELIGION AND SCIENCE. By JOHN WM. DRAPER, M. D., author of "'l'he Intellectual Development of Europe." Price, \$1.75.

No. 13. THE DOCTRINE OF DESCENT AND DARWINISM. By Prof. Oscar Schmidt, Strasburg University. Price, \$r.50.

NO. 14. THE CHEMISTRY OF LIGHT AND PHOTOGRAPHY. In its Application to Art, Science, and Industry. By Dr. Hermann VoGEL. One Hundred Illustrations. (In press.)

No. 15. FUNGI; their Nature, Influence, and Uses. By M C. Cooke, M. A., LL. D. Edited by Rev. M. J. Berkeley, M. A., F. L. S. With Iog Illustrations. (In press.)

No. 16. OPTICS. By Prof. Lommel, University of Erlangen. (In press.)

Other eminent authors, as WAillace, Helmholtz, Parks, Milne-Edwards, and HAECKEL, have given strong encouragement that they will also take part in the enterprise.

D. APPLETON \& CO., Publishers, 549 \& 55I Broadway, N. Y. 


\section{ReCENT Publications.-SCIENTIFIC.}

THE PRINCIPLES OF IIENTAL PHYSIOLOGY. With their Ap. plications to the Training and Discipline of the Mind, and the Study of its Morbid Conditions. By W. B. CARPENTER, F. R. S., etc. Illustrated. I2mo. 737 pages. Price, $\$ 3.00$.

"The work is probably the ablest exposition of the subject which has been given to the world, and goes far to establish a new system of Menta! Philosophy, upon a much broader and more substantial basis than it has heretofore stood."-St. Louis Democrat.

"Let us add that nothing we have said, or in any limited space could say, would give an adequate conception of the valuable and curious collection of facts bearing on morbid mental conditions, the learned physiological exposition, and the treasure-house of useful hints for mental training, which make this large and yet very amusing, as well as instructive book, an encyclopædia of well-classified and often very startling psychoiogical experiences."-London Spectaior.

THE EXPANSE OF HEAVEN. A Series of Essays on the Wonders of the Firmament. By R. A. Proctor, B. A.

"A very charming work; cannot fail to lift the reader's mind up 'through Nature's work to Nature's God." "L-London Standard.

"Prof. R. A. Proctor is one of the very few rhetorical scientists who have the art of making science popular without making it or themselves contemptible. It will be hard to find anywhere else so much skill in effective expression, combined with so much genuine astronomical learning, as is to be seen in his new volume."-Christian Union.

PHYSIOLOGY FOR PRACTICAL USE. By various Writers. Edited by JAMES Hinton. With 50 Illustrations. I vol., I 2 mo. Price, $\$ 2.25$.

"This book is one of rare value, and will prove useful to a large class in the community. Its chief recommendation is in its applying the laws of the science of physiology to cases of the deranged or diseased operations of the organs or processes of the human system. It is as thoroughly practical as is a book of formulas of medicine, and the style in which the information is given is so entirely devoid of the mystification of technical or scientific terms that the most simple can easily comprehend it."-Boston Gazette.

"Of all the works upon health of a popular character which we have met with for some time, and we are glad to think that this most important branch of knowledge is becoming more enlarged every day, the work before us appears to be the simplest, the soundest, and the best."-Chicago Inter-Ucean.

THE GREAT ICE AGE, and its Relations to the Antiquity of Man. By JAMES GeIKIE, F. R. S. E. With Maps, Charts, and numerous lllustrations. I vol., thick I2mo. Price, $\$ 2.50$.

"' The Great Ice Age' is a work of extraordinary interest and value. The subject is peculiarly attractive in the immensity of its scope, and exercises a fascination over the imagination so absorbing that it can scarcely find expression in words. It has all the charms of wonder-tales, and excites scientific and unscientific minds alike."-Boston Gazette.

"Every step in the process is traced with admirable perspicuity and fullness by Mr. Geikie."-London Saturday Review.

"' The Great Ice Age,' by James Geikie, is a book that unites the popular and abstruse elements of scient:fic research to a remarkable degree. The author recounts a story that is more romantic than nine novels out of ten, and we have read the book from first to last with unflagging interest."-Boston Commer. cial Bulletin.

ADDRESS DELIVERED BEFORE THE BRITISH ASSOCIATION, assembled at Belfast. By JoHn Tyndal, F. R. S., President. Revised, with additions, by the author, since the delivery. I2mo. I20 pages. Paper. Price, 50 cents.

This edition of this now famous address is the only one authorized by the author, and contains additions and corrections not in the newspaper reports.

THE PHYSIOLOGY OF IMAN. Designed to represent the Existing State of Physiological Science as applied to the Functions of the Human Body. By Austin Fint, Jr., M. D. Complete in Five Volumes, octavo, of about 500 pages each, with ro5. Illustrations. Cloth, $\$ 22.00$; sheep, $\$ 27.00$. Each volume sold separately. Price, cloth, $\$ 4.50 ;$ sheep, $\$ 5.50$. The fifth and last volume has just been issued.

The abcve is by far the most complete work on human phrsiology in the English language. It treats of the functions of the human body from a practical point of $\mathrm{view}$, and is enriched by many original experiments and observations by the author. Considerable space is given to physiological anatomy, particularly the structure of glandular organs, the digestive system, nervous system, blocd-vessels, organs of epecial sense, and rrgans of generation. It not only considers the various functions of the body, from an experimental stand-point, but is peculiarly rich in citations of the literature of physiology. It is therefore invaluable as a work of reference for those who wish to study the subject of physiology exhaustively. As a complete treatise on a subject of such interest, it should be in the libraries of literary and scientific men, as well as in the hands of practitioners and students of medicine. Illustrations are introduced wherever they are necessary for the elucidation of the text.

D. APPLETON \& CO., Publishers, 549 \& 55I Broadway, N. Y. 


\section{RECENT PUBLICATIONS.}

\section{THE NATIVE RACES OF THE PACIFIC STATES.}

By Herbert H. Bancrogt. To be completed in 5 vols. Vol. I. now ready. Containing Wild Tribes: their Manners and Customs. I vol., 8vo. Cloth, $\$ 6$; sheep, $\$ 7$.

"We can only say that if the remaining volumes are executed in the same spirit of candid and careful investigation, the same untiring industry, and intelligent good sense, which mark the volume before us, Mr. Bancroft's 'Native Races of the Pacific States will form, as regards aboriginal America, an encyclopædia of knowledge not only un equaled but unapproached. A literary enterprise more deserving of a generous sympathy and support has never been undertaken on this side of the Atlantic." - FrANCIS PARKMAN, in the North American Review.

"The industry, sound judgment, and the excellent literary style displayed in this work, cannot be too highly praised." - Boston F'ost.

\section{A BRIEF HISTORY OF CULTURE.}

\section{By John S. Hittell. I vol., I2mo. Price, \$1.50.}

"He writes in a popular style for popular use. He takes ground which has never been fully occupied before, although the general subject has been treated more or less distinctly by several writers. . . . Mr. Hittell's method is compact, embracing a wide field in a few words, often presenting a mere hint, when a fuller treatment is craved by the reader; but, although his book cannot be commended as a model of literary art, it may be consulted to great advantage by every lover of free thought and novel suggestions." $-N$. Y. Tribune.

\section{THE HISTORY OF THE CONFLICT BETWEEN RE- LIGION AND SCIENCE.}

By John W. Draper, M. D., author of "The Intellectual Develop. ment of Europe." I vol., I2mo. Cloth. Price, \$1.75.

"The conflict of which he treats has been a mighty tragedy of humanity that has dragged nations into its vortex and involved the fate of empires. The work, though small, is full of instruction regarding the rise of the great ideas of science and philosophy; and he describes in an impressive manner and with dramatic effect the way religious authority has employed the secular power to obstruct the progress of knowledge and crush out the spirit of investigation. While there is not in his book a word of disrespect for things sacred, he writes with a directness of speech, and a vividness of characterization and an unflinching fidelity to the facts, which show him to be in thorough earnest with his work. The "History of the Conflict between Religion and Science' is a fitting sequel to the 'History of the Intellectual Development of Europe,' and will add to its author's already high reputation as a philosophic historian " $-N$. Y. Tribune.

\section{THEOLOGY IN THE ENGIISH POETS.}

COWPER, COLERIDGE, WORDSWORTH, and BURNS. By Rev. STOPFORD BRooke. I vol., I2mo. Price, $\$ 2$.

"Apart from its literary merits, the book may be said to possess an independen value, as tending to familiarize a certain section of the English public with more enlightened views of theology."-London A thenceum.

\section{BLOOMER'S COMIMERCIAL CRYPTOGRAPH.}

A Telegraph Code and Double Index-Holocryptic Cipher. By J. G. BloOMER. I vol., 8vo. Price, \$5.

By the use of this work, business communications of whatever nature may be teto graphed with secrecy and economy.

D. APPLETON \& CO., Privishers, New Yor's. 


\section{THE EXPANSE OF HEAVEN;}

A Series of Essays on the Wonders of the Firmament.

By R. A. PROCTOR, B. A.

I vol., I2mo. Cloth. . . . . Price, $\$ 2.00$.

"It is Mr. Proctor's good fortune that not only is he one of the greatest of living astronomers, but that he has a power of imparting knowledge that is not equaled by any living astronomer. His style is as lucid as the light with which he deals so largely, and the plainest of readers can go along with him with entire ease, and comprehend all that he says on the grandest subject ever discussed by mortal intelligence. Most scientific writers either cannot or will not so use the pen as to make themselves understood by the many; not so with Mr. Proctor: he both can and does so write as to command the attention of the million, and this too without in the least derogating from the real dignity of his sublime theme. Few of us can study astronomy, because that implies a concentrated devotion to an inexhaustible matter, but we all can read astronomical works to our great advantage if astronomers who write will but write plainly; and in that way, without having the slightest claim to be spoken of as "scientists," we can acquire no ordinary amount of knowledge concerning things that are of the loftiest nature, and the effect of which must be to elevate the mind. Such a book as 'The Expanse of Heaven' cannot fail to be of immense use in forwarding the work of education even when it is read only for amusement, so forcible is the impression it makes on the mind from the importance of the subjects treated of, while the manner of treatment is so good."-Boston Traveller.

" Since the appearance of Ennis's book on 'The Origin of the Stars,' we have not read a more attractive work on astronomy than this. It is learned enough to be instructive, and light enough to be very entertaining.' -Alta California.

"It reads like a work of fiction, so smooth and consecutive is it; but it inspires the worthiest thoughts and the highest aspirations." Boston Commonwealth.

" Perfectly adapted to their purposes, namely, to awaken a love for science, and at the same time to convey, in a pleasant manner, some elementary facts."-Church Herald.

"This is not a technically scientific work, but an expression of a true scholar's conception of the vastness and grandeur of the heavens. There is no dry detail, but blended with the scholar's discoveries are the poet's thoughts, and a true recognition of the Almighty's power." -Troy Times.

\section{APPLETON \& CO., Publishers,}

$549 \& 55$ I BROADWAY, N. Y. 


\section{A New Magazine for Students and Cultivated Readers.}

\section{T H E \\ POPULAR SCIENCE MONTHLY,}

CONDUCTED BY

Professor E. L. YOUMANS.

THE growing importance of scientific knowledge to all classes of the community calls for more efficient means of diffusing it. THE POPULAR SCIENCE Monthly has been started to promote this object, and supplies a want met by no other periodical in the United States.

It contains instructive and attractive articles, and abstracts of articles, original, selected, and illustrated, from the leading scientific men of different countries, giving the latest interpretations of natural phenomena, explaining the applications of science to the practical arts, and to the operations of domestic life.

It is designed to give especial prominence to those branches of science which help to a better understanding of the nature of man; to present the claims of scientific education; and the bearings of science upon questions of society and government. How the various subjects of current opinion are affected by the advance of scientific inquiry will also be considered.

In its literary character, this - periodical aims to be popular, without being superficial, and appeals to the intelligent reading-classes of the community. It seeks to procure authentic statements from men who know their subjects, and who will address the non-scientific public for purposes of exposition and explanation.

It will have contributions from Herbert Spencer, Professor Huxley, Professor Tyndall, Mr. Darwin, and other writers identified with speculative thought and scientific investigation.

THE POPULAR SCIENCE MONTHLY is published in a large octavo, handsomely printed on clear type. Terms, Five Dollars per annum, or Fifty Cents per copy.

\section{OPINIONIS OF THE PRESS.}

"Just the publication needed at the present day."-Montreal Gazette.

"It is, beyond comparison, the best attempt at jourralism of the kind ever made in this country."-Home Fournal.

"The initial number is admirably constituted."-Evening Mail.

"In our opinion, the right idea has been happily hit in the plan of this new monthly." -Buffalo Courier.

"A journal which promises to be of eminent value to the cause of popular education in this country." $-N$. I. Tribune.

\section{IMPORTANT TO CLUBS.}

The Popular Science Monthly will be supplied at reduced rates with any periodiial published in this country.

Any person remitting Twenty Dollars for four yearly subscriptions will receive an extra copy gratis, or five yearly subscriptions for $\$ 20$.

The Popular Science Monthly and Appletons' Journal (weekly), per annum, $\$ 8 . \infty$

ए Payment, in all cases, must be in advance.

Remittances should be made by postal money-order or check to the Publishers,

\section{APPLETON \& CO., 549 \& 551 Broadway, New Yor'k.}








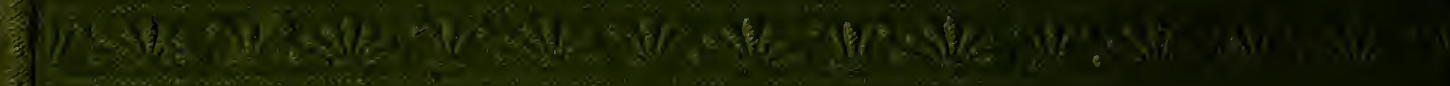

19.

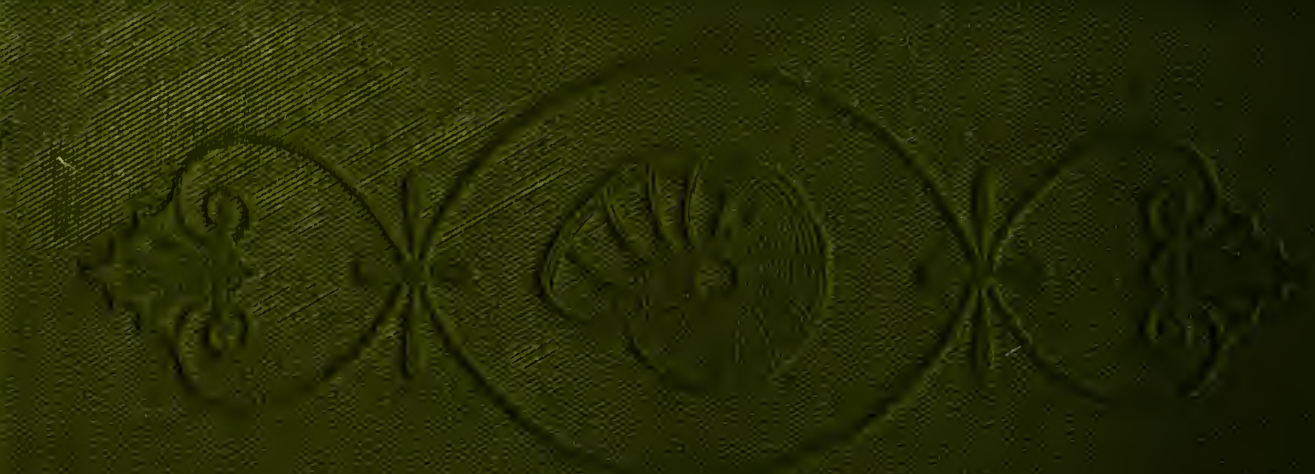

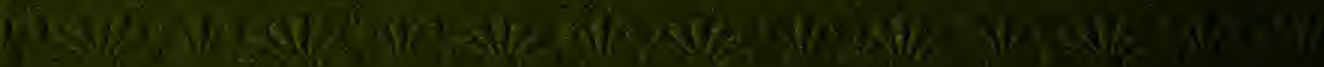

